UNIVERSIDADE DE SÃO PAULO

FACULDADE DE FILOSOFIA, LETRAS E CIÊNCIAS HUMANAS

DEPARTAMENTO DE GEOGRAFIA

PROGRAMA DE PÓS-GRADUAÇÃO EM GEOGRAFIA HUMANA

LARISSA SOARES DE ARAUJO

A LUTA PELA REFORMA URBANA ATRAVÉS DO OLHAR DA GEOGRAFIA: ORIGENS E INSERÇÃO DA AGB

VERSÃO CORRIGIDA

SÃO PAULO 
LARISSA SOARES DE ARAUJO

\title{
A LUTA PELA REFORMA URBANA ATRAVÉS DO OLHAR DA GEOGRAFIA: ORIGENS E INSERÇÃO DA AGB
}

\author{
VERSÃO CORRIGIDA
}

Dissertação apresentada ao Programa de Pós-Graduação em Geografia Humana, do Departamento de Geografia da Faculdade de Filosofia, Letras e Ciências Humanas da Universidade de São Paulo para a obtenção do título de Mestre em Geografia Humana.

Orientadora: Prof $^{a}$ Dr. ${ }^{\text {a }}$ Simone Scifoni 
Autorizo a reprodução e divulgação total ou parcial deste trabalho, por qualquer meio convencional ou eletrônico, para fins de estudo e pesquisa, desde que citada a fonte.

Catalogação na Publicação

Serviço de Biblioteca e Documentação

Faculdade de Filosofia, Letras e Ciências Humanas da Universidade de São Paulo

\begin{tabular}{|c|c|}
\hline \multirow[t]{3}{*}{ A6581 } & 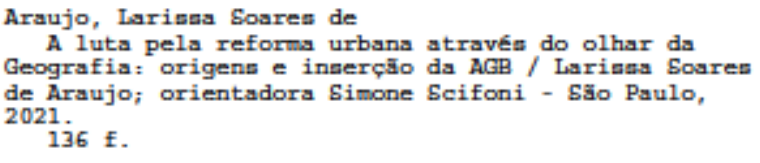 \\
\hline & $\begin{array}{l}\text { Dimertaç̄̃o (Meatrado) - Faculdade de Filonofia, } \\
\text { Letras e Ciencias Humanas da Univeraidade de Säo } \\
\text { Paulo. Departamento de Geografia. Área de } \\
\text { concentração: Geografia Humana. }\end{array}$ \\
\hline & $\begin{array}{l}\text { 1. Reforma Urbana. 2. Aanociaçio doa Ge6grafoa } \\
\text { Braaileirou. } 3 \text {. Planejamento. } 4 \text {. Geografia Urbana. } 5 . \\
\text { Geografia Critica - I. Scifoni, Simone, orient. II. } \\
\text { Titulo. }\end{array}$ \\
\hline
\end{tabular}


\$. fl h universidade de SÃo Paulo

FACULDADE DE FILOSOFIA, LETRAS E CIÊNCIAS HUMANAS

\section{ENTREGA DO EXEMPLAR CORRIGIDO DA DISSERTACÃO/TESE}

\section{Termo de Ciência e Concordância do (a) orientador (a)}

Nome do (a) aluno (a): Larissa Soares de Araujo

Data da defesa: 08/02/2021

Nome do Prof. (a) orientador (a): Simone Scifoni

Nos termos da legislação vigente, declaro ESTAR CIENTE do conteúdo deste EXEMPLAR CORRIGIDQ elaborado em atenção às sugestões dos membros da comissão Julgadora na sessão de defesa do trabalho, manifestando-me plenamente favorável ao seu encaminhamento e publicação no Portal Digital de Teses da USP.

São Paulo, 07/04/2021

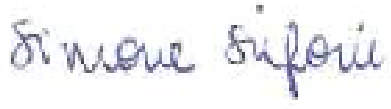

(Assinatura do (a) orientador (a) 
Nome: ARAUJO, Larissa Soares de.

Título: A luta pela reforma urbana através do olhar da Geografia: origens e inserção da AGB

Dissertação apresentada ao Programa de Pós-Graduação em Geografia Humana, do Departamento de Geografia da Faculdade de Filosofia, Letras e Ciências Humanas da Universidade de São Paulo para a obtenção do título de Mestre em Geografia Humana.

Aprovada em: 08 de fevereiro de 2021.

Banca Examinadora:

Prof. Dr. Arlete Moyses Rodrigues

Instituição: Universidade de Campinas - UNICAMP

Julgamento: Aprovada

Prof. Dr. José Borzacchiello da Silva

Instituição: Pontifícia Universidade Católica do Rio de Janeiro - PUC Rio

Julgamento: Aprovada

Prof. Dr. Charlles da França Antunes

Instituição: Faculdade de Formação de Professores da Universidade Estadual do Rio de Janeiro - UERJ

Julgamento: Aprovada 
Aos meus pais, fortalezas de todas as horas. Aos meus amigos, por dividirem o tempolespaço comigo e fazerem a vida mais especial. Aos geógrafos lembrados nessa pesquisa que lutaram/lutam por um país sem desigualdade. 


\section{AGRADECIMENTOS}

Agradeço a professora Simone que, com a sua sensibilidade, conhecimento e confiança depositada, fez esse percurso da pesquisa acadêmica ser menos inquietante e mais humano. Esse percurso não é de agora.... Começou na iniciação científica e teve ainda o TGI. E pensar que tudo começou com um trabalho de campo para o ABC da disciplina de Geografia Urbana do segundo ano de faculdade...

Obrigada aos "Simonais", nome carinhoso do Grupo de Estudos da professora Simone: João, Beto, Henrique, Laura, Larissa, Adriana, Celso, Amanda, Geinne, Danilo e Cláudio. Obrigada pelos ouvidos atentos e opiniões generosas sobre a minha pesquisa. Escrever esse texto foi também lembrar das falas de vocês e me sentir grata. Obrigada também pelas trocas nas rampas do prédio, nos cafés, no dia-a-dia digital.

Obrigada ao pessoal da AGB, que não mediu esforços em ajudar. Ao Aírton, Paulo e Rita, pelo apoio e explicações tão importantes. Ao Caio, pela ajuda imensa no acesso aos documentos que eram indispensáveis para a pesquisa. Ao João, pelo incentivo desde o começo e a amizade. Agora somos também colegas de prefeitura e vizinhos de ZL. Esse obrigada se estende ao "pessoal das antigas", que gentilmente cederam seus tempos para entrevistas, como o professor Douglas, lá da Espanha, e o professor Diamantino, que aceitou também ser da minha banca de qualificação.

À professora Arlete Moyses, pelos e-mails prontamente respondidos, entrevista, dicas importantíssimas na qualificação e grande exemplo de trajetória. Aos professores Eliseu Spósito e Maria Encarnação Spósito pela imensa generosidade em aceitarem convites que possivelmente pareceram vagos, mas que que foram aceitos sem pensar duas vezes. Sem dúvida nenhuma, essas conversas vieram numa hora delicada da pesquisa e depois de todas as dicas e experiências compartilhadas, a escrita pode acontecer. À prima e professora Nilce Aravecchia, sempre atenta e disponível, gratidão pelo seu carinho e generosidade em compartilhar o conhecimento. À professora Maria Adélia, muito solícita e gentil, que com muita paciência compartilhou tanta experiência de vida.

Agradeço também à galera da EMEF Arthur Alvim, em especial ao Rafa, meu amigo-irmão companheiro de tantos momentos especiais, e a Nivia, parceira e amiga; com quem divido dentro e fora da escola as angústias e as grandezas de ser professora de escola pública na zona leste de São Paulo. Quero deixar registrado também meu carinho 
e respeito pelos alunos, responsáveis pelos maiores aprendizados que já tive em toda a vida.

Essa pesquisa não teria chegado ao fim sem a cumplicidade dos meus amigos. Obrigada aos amigos de Itápolis: Caio, Gabi, Jéssica, Maíra, por me ensinarem tanto sobre a amizade (duradoura). Ao Leandro, Caio e Maria, amigos tão especiais e queridos que fiz em São Paulo. Um obrigada sem fim ao grupo do "Tripé”: Ícaro e Juberlândia. O nome do grupo não poderia ser melhor, vocês são o meu apoio e equilíbrio nessa vida frenética e emocionante da capital. Eu admiro e amo muito todos vocês!

Um agradecimento especial aos meus pais, que compreenderam minhas idas a menos para a minha casa de origem e que me apoiaram em tudo que decidi fazer na vida, sempre prontos para o que eu precisasse; a minha tia; a Anna Lívia, que agora também é amante das palavras, e meus avós, sempre esbanjando amor e proteção. Obrigada! Muito amor por vocês. 


\section{RESUMO}

ARAUJO, Larissa S. A luta pela reforma urbana pelo olhar da Geografia: origens e inserção da AGB. 2020. Dissertação (Mestrado) - Faculdade de Filosofia, Letras e Ciências Humanas, Universidade de São Paulo, 202

Essa dissertação de mestrado apresenta a trajetória de transformações da Associação dos Geógrafos Brasileiros (AGB) e do pensamento da geografia urbana que levaram à inserção e à participação da associação na luta pela reforma urbana, no contexto das discussões da Constituinte, do Movimento Nacional de Reforma Urbana e do Fórum Nacional de Reforma Urbana. Entendemos que o caminho que levou a AGB a atuar nesse movimento da sociedade do final da década de 1980 tem aspectos teóricos e práticos, entendidos em uma relação dialética. Nesse sentido, muitos geógrafos viram a necessidade de desenvolver uma ciência alinhada com a práxis social, o que não ocorreu sem embates internos e sem resistência em um contexto de ditadura militar. Para resgatar esse caminho teórico e prático buscamos relacionar a atuação da AGB às abordagens adotadas pela geografia urbana em diferentes momentos, além das atividades profissionais dos geógrafos ligadas ao urbano e as cidades. Por fim, entendemos que o envolvimento da AGB na luta pela reforma urbana apresentou limitações, pois a participação foi de alguns geógrafos que estavam dentro da AGB e não da Associação de forma coesa.

Palavras-chave: Reforma urbana; Associação dos Geógrafos Brasileiros; Planejamento; Geografia Urbana; Geografia Crítica 


\begin{abstract}
ARAUJO, Larissa S. The struggle for urban reform through the gaze of Geography: origins and insertion of AGB. 2020. Dissertação (Mestrado) - Faculdade de Filosofia,
\end{abstract}

This master's dissertation presents the trajectory of transformations of the Association of Brazilian Geographers (AGB) and the thought of urban geography that led to the insertion and participation of the association in the struggle for urban reform, in the context of the discussions of the Constituent Assembly, the National Movement for urban reform and the National Forum for urban reform. We understand that the path that led AGB to act in this movement of society of the late 1980s has theoretical and practical aspects, understood in a dialectical relationship. In this sense, many geographers saw the need to develop a science aligned with social praxis, which did not occur without internal clashes and without resistance in a context of military dictatorship. To rescue this theoretical and practical path we seek to relate the action of the AGB to the approaches adopted by urban geography at different times, in addition to the professional activities of Geographers linked to urban and cities. Finally, we understand that the involvement of the AGB in the struggle for urban reform presented limitations, since the participation was of some geographers who were within the AGB and not the Association in a cohesive way.

Keywords: Urban Reform; Association of Brazilian Geographers; Planning; Urban Geography; Critical Geography. 


\section{LISTAS DE FIGURAS}

Figura 1 - Transição de geógrafos de SP e RJ na década de 1950 ................................ 13

Figura 2 - Principais reformas estatutárias da AGB .................................................. 22

Figura 3 - Jornal da AGB que trata da aprovação do estatuto de 1979 ............................. 60

Figura 4 - Editorial da edição ${ }^{\circ} 55$ do BPG do ano de 1978 ....................................... 78

Figura 5 - Divulgação de ato do MNRU em defesa de emendas populares no período da

Constituinte

Figura 6 - Divulgação do MNRU sobre campanha de coleta de assinaturas e

mobilização no período da Constituinte 98

Figura 7 - Esboço escrito por Arlete Moyses sobre os quatro primeiros Encontros do

FNRU 103

\section{LISTAS DE QUADROS}

Quadro 1 - Publicações sobre cidade e urbano no BPG (1934-1970) ............................ 43

Quadro 2 -Publicações sobre cidade e o urbano no BCG (1934-1970) ........................... 47

Quadro 3 - Publicações sobre a cidade e o urbano no BPG (Década de 1970).............. 81

Quadro 4 - Publicações sobre a cidade e o urbano no BCG (Década de 1970) .............. 85

Quadro 5 - Documentos da AGB relacionados ao período do Congresso Constituinte. 93

Quadro 6 - Publicações sobre cidade e o urbano no BPG (Década de 1980)................ 105

Quadro 7 - Publicações sobre cidade e o urbano no BCG (Década de 1980) ............... 110

\section{LISTAS DE FOTOS}

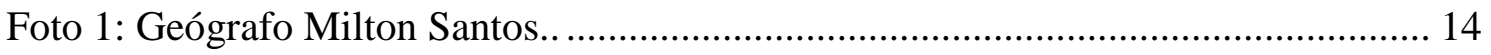

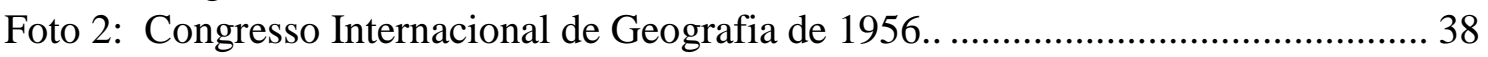

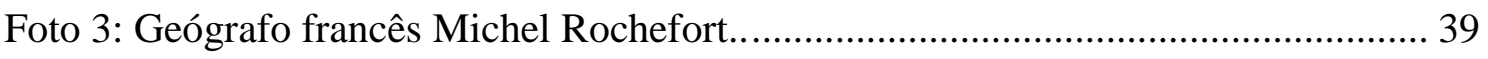

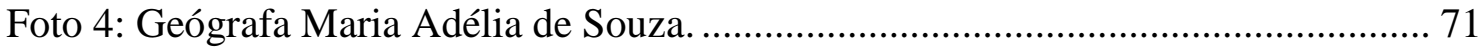

Foto 5 - Mesa do VII ENG, em Maceió, 1988.............................................................. 92

Foto 6 - Geógrafos na manifestação em Alagoas......................................................... 92

Foto 7: Geógrafo mineiro William Rosa................................................................ 101 


\section{SUMÁRIO}

Introdução: o tema e o problema de pesquisa......................................................

Capítulo 1: A geografia urbana: iniciando o debate.................................................10

Capítulo 2: Origens da AGB e o pensamento na geografia urbana (1934-1970) .......19

2.1. Urbanização, crescimento das metrópoles e conflitos urbanos.....................23

2.2. O início de um debate sobre a reforma urbana...............................................30

2.3. O IBGE e a Geografia Urbana Aplicada......................................................32

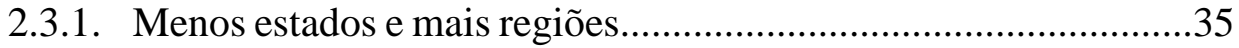

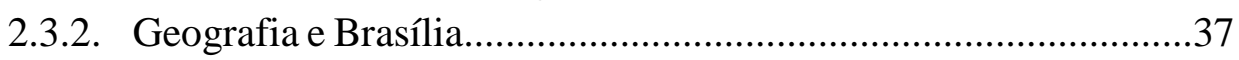

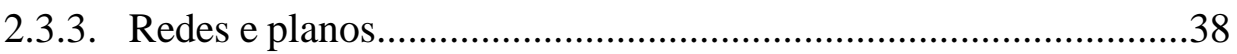

2.4. A cidade e o urbano nos boletins da AGB..................................................4

Capítulo 3: A transformação da AGB e os embates da Geografia na década de

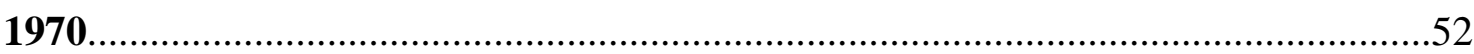

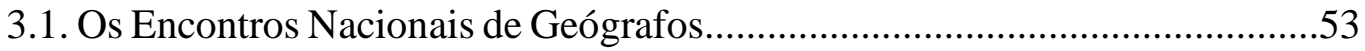

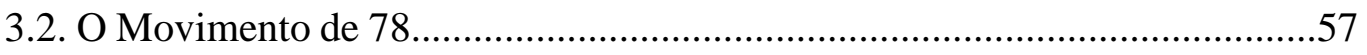

3.3. As cidades: ditadura, desigualdade e movimentos de resistência...................61

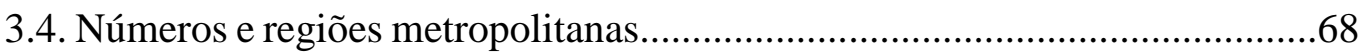

3.5.O II PND e o Capítulo da Política Urbana.....................................................70

3.6. A cidade e o urbano nos boletins da AGB...................................................76

Capítulo 4: A AGB e a luta pela reforma urbana no período do Congresso

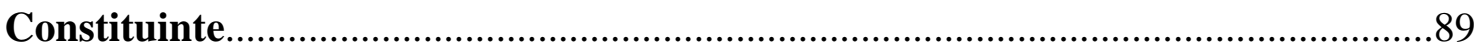

4.1. A emenda popular pela reforma urbana e a Constituição...............................95

4.2.A Comissão de Assuntos Urbanos da AGB....................................................99

4.3.O Fórum Nacional de Reforma Urbana.....................................................101

4.4. As cidades e o urbano nos boletins da AGB..............................................104

4.5. Reconhecimentos e limitações do papel da AGB na luta pela reforma urbana. 


\section{INTRODUÇÃO: o tema e o problema de pesquisa}

A luta pela reforma urbana no Brasil teve um amplo papel mobilizador de diferentes sujeitos políticos no país, como movimentos sociais urbanos, entidades acadêmicas e ONGs. Hoje, em um contexto de aprofundamento das políticas neoliberais, a "agenda" da reforma urbana encontra-se em uma difícil e preocupante situação. Para parte dos que ainda estão na luta, uma das questões mais urgentes é dar continuidade ao Programa Minha Casa Minha Vida - Entidades, modalidade do PMCMV que se realiza por autogestão e atende a população de 0 a 3 salários mínimos.

Segundo Fernandes (2019), o surgimento da expressão "reforma urbana" tem suas origens em Cuba. Em 1960, quando o país ainda começava a se direcionar para o programa de luta da Revolução, ocorreu a aprovação da "Ley da Reforma Urbana", cujo objetivo era combater o uso especulativo do solo urbano, marcando o fim de um programa cubano de caráter reformista. O Brasil, ainda de acordo com a autora, possivelmente foi o segundo país a adotar essa expressão.

As primeiras menções sobre uma "reforma urbana" no Brasil estão associadas às discussões sobre as reformas de base durante o governo de João Goulart, no começo dos anos 1960. O marco mais retomado pela literatura é 1963, quando o Instituto de Arquitetos do Brasil e o Instituto de Previdência e Aposentadoria dos Servidores do Estado organizaram o Seminário de Habitação e de Reforma Urbana, que ocorreu em Petrópolis e em São Paulo (SANTO AMORE, 2013). Assim como em Cuba, como analisou Fernandes (2019), essa escolha mostra um protagonismo conferido às cidades, mas as lutas dos trabalhadores naquele período estavam ainda centradas na indústria e no campo, sendo a ideia de reforma urbana muito diferente da que viria a se transformar na década de 1980, quando o processo de urbanização e o crescimento das metrópoles no Brasil estavam avançados.

É no período do Congresso Constituinte de 1987 que esse debate é amplamente retomado por diferentes entidades e movimentos sociais, que se unem para elaborar uma emenda popular pela reforma urbana para a Constituição. Nesse contexto, a condição dos trabalhadores que moravam nas periferias das grandes cidades era extremamente precária: favelas, ocupações de terra, falta de saneamento básico, de atendimento médico e tantas outras ausências. A aglutinação das forças sociais e acadêmicas resultou em conquistas 
na Constituição de 1988, como a incorporação da função social da propriedade e da cidade e a definição do Plano Diretor como instrumento obrigatório para os municípios com mais de 20.000 habitantes (FERREIRA, 2012), apesar de todas as limitações e contradições que acompanham as práticas de planejamento urbano (RODRIGUES, 2013).

Os encontros e articulações desse período também tiveram como desdobramento a organização do Fórum Nacional de Reforma Urbana - FNRU, que ampliou o Movimento surgido no período da Constituinte, integrando diferentes movimentos sociais urbanos, ONGs e entidades profissionais (SANTO AMORE, 2013). A partir da construção desse espaço de discussão, novas pautas entraram na agenda da reforma urbana, como por exemplo o Estatuto da Cidade, discutido por toda a década de 1990 e aprovado em 2001 e a criação em 2003 do Ministério das Cidades e do Conselho das Cidades (órgão consultivo do Ministério das Cidades).

Essa pesquisa pode ser considerada um desdobramento das pesquisas de iniciação científica e trabalho de graduação individual desenvolvidas em outros momentos da formação. $\mathrm{Na}$ iniciação, os estudos foram direcionados para uma Associação de Moradores em Diadema que, em um primeiro momento da trajetória, organizava ocupações como forma de reivindicações de terra e moradia e, posteriormente ao Plano Diretor de 1994 do munícipio, centrou a luta entorno do instrumento urbanístico das AEIS. No final da graduação, a mesma Associação de Moradores foi objeto de estudo, no entanto, a disputa tinha passado a ser pelos recursos do Programa Minha Casa Minha Vida - Entidades. Dessa maneira, é possível perceber que as pautas da reforma urbana sempre foram de muito interesse nos temas de pesquisa.

Nesse contexto de lutas, estratégias, articulações em torno do tema da reforma urbana, uma questão se coloca como ponto de partida para essa pesquisa: qual o papel dos geógrafos nessas trajetórias? Existe uma integração dos geógrafos nessas lutas de uma forma organizada?

Foi a partir dessa questão que adotamos para essa pesquisa de mestrado um novo sujeito de luta, uma nova Associação, que dessa vez tem um caráter político-acadêmico: a Associação dos Geógrafos Brasileiros - AGB. Criada em 1934, tem sua origem atrelada ao surgimento da Universidade de São Paulo; da Faculdade de Filosofia, Ciências e Letras e do curso de História e Geografia dessa mesma faculdade. Essa entidade, que ocupa um lugar importante na história da ciência geográfica e na institucionalização da geografia 
moderna no Brasil, passa ao longo de sua trajetória por modificações profundas, culminando no final da década de 1980, período de abertura democrática brasileira, em um importante engajamento social, cujas práticas relacionadas ao tema do urbano e à reforma urbana são de grande interesse para essa pesquisa.

Como nos indicaram Antunes e Neto (2008), a AGB tornou-se mais combativa a partir de 1978, quando os estudantes, em meio ao contexto de ditadura militar, exigiram no Encontro Nacional de Geógrafos de Fortaleza uma mudança de estatuto para que todos os geógrafos, inclusive aqueles em formação, pudessem participar de forma igual nas decisões da entidade. Naquele momento, ocupar a AGB representava um meio de colocar todo o pensamento crítico da época, que repercutiu fortemente em nossa ciência, a serviço da democracia e das lutas sociais.

Embora a geografia crítica não tenha aparecido somente após 1978, podemos dizer que a partir desse momento os geógrafos e a AGB fizeram repercutir com força uma ciência alinhada com a "práxis". Assim, foi o resultado de um processo que aconteceu em meio à ditadura, quando esses sujeitos buscaram brechas para cada vez mais divulgar e produzir análises que se debruçavam sobre a realidade política e social da época, inclusive sobre os problemas que assolavam a classe trabalhadora nas áreas urbanas do país por meio de uma geografia urbana crítica.

O objetivo dessa pesquisa é entender o processo que levou à inserção da AGB na luta pela reforma urbana no período efervescente da Constituinte. Afinal, o que motivou uma entidade que tem origem na década de 1930, período de afirmação da geografia moderna no Brasil, e que tem como principal objetivo a produção e a divulgação do conhecimento, a se engajar junto aos movimentos sociais? Nesse sentido, procuramos jogar luz no caminho percorrido pelos geógrafos e pela AGB, mostrando como em suas fases iniciais a geografia brasileira estava mais atrelada a um discurso descritivo e aplicado e como, sobretudo após 1978, passou a olhar fortemente, por meio da AGB, para a realidade social e dos movimentos sociais, engajando-se na luta pela reforma urbana.

Incluídos nesse processo estão as lutas anteriores dentro da própria comunidade geográfica, que sentia a necessidade de reformular o caráter epistemológico da Geografia e da geografia urbana que era feitas até então. Estão presentes os percursos da própria sociedade, onde grupos e movimentos sociais se articulavam em meio ao regime militar para exigir democracia e direitos sociais. Estão também as transformações do espaço, 
cada vez mais urbanizado, e as periferias cada vez mais expandidas, carentes de serviços e ao mesmo tempo com trabalhadores buscando se organizar. Todos esses aspectos vão se atrelar à trajetória da Associação dos Geógrafos Brasileiros, levando a sua integração na luta pela reforma urbana no período da Constituinte no Brasil.

Para resgatar esse caminho, que é teórico e prático, levantamos a trajetória da geografia urbana e também das atividades dos geógrafos ligadas ao urbano e as cidades, desde o surgimento da geografia moderna na década de 1930. Dentro do recorte adotado para a pesquisa, que é de 1934 a 1989, outros sujeitos e instituições foram importantes, como foi o caso do Instituto Brasileiro de Geografia e Estatística - IBGE e dos geógrafos que lá trabalharam. A pesquisa buscou, assim, mostrar como, em diferentes momentos, se dá a relação entre a geografia urbana, o pensamento geográfico, a atuação da AGB e a realidade concreta das cidades brasileiras, como momentos que antecedem as transformações da entidade a partir do final dos anos 1970 e que a levaram a se engajar na luta pela reforma urbana.

Nesse sentido, reconhecemos o par entre teoria e prática como indissociável, o que é a base do pensamento marxista:

...o pensamento marxista reclama o deslocamento da análise do plano da ontologia, e também do plano da epistemologia - prisioneiros do mundo abstrato das ideias - para aquele que articula a teoria (plano da produção do conhecimento como ato de compreensão do mundo) e a prática (práxis) em sua indissociabilidade (CARLOS, 2016, p. 26).

A geografia urbana, sem surpresas, seguiu o caminho das influências mais amplas que foram marcando a trajetória da Geografia, e em sua fase inicial era marcada pelas monografias urbanas características da geografia tradicional. Toda a década de 1970 foi muito emblemática, porque é quando se dão os confrontos entre a geografia quantitativa e a geografia crítica em espaços como os Encontros Nacionais de Geografia - ENG da AGB. Os embates só não foram mais fortes nos primeiros encontros da década em função das constantes espionagens do regime militar. Já as produções críticas sobre geografia urbana apareceriam publicadas nos boletins de Geografia com maior frequência somente na década de 1980, após as "arrumações da casa", ou seja, da própria ciência geográfica (ABREU, 1994).

A prática dos geógrafos inseridos na área das cidades e do urbano esteve da década de 1930 até meados da década de 1970 atrelada fortemente ao planejamento. Dessa maneira, os geógrafos do IBGE ou até mesmo aqueles convidados pelos militares 
participaram de uma estruturação da política urbana baseada sobretudo no planejamento regional e territorial e influenciada pelas bases da geografia urbana da época. Após a restruturação teórica e metodológica da Geografia no final dos anos 1970, a prática dos geógrafos passou a acontecer mais na "chave" das cidades e menos do território ou da região, tendo como principal sujeito desse novo momento a AGB.

Entender esse processo, em nossa visão, tem grande importância atual para a comunidade geográfica, pois possibilita uma reflexão sobre a prática do geógrafo nos assuntos da sociedade civil. Além disso, entendemos que a construção desse trabalho contribui para o fortalecimento da memória das lutas sociais pela reforma urbana e dos sujeitos que estiveram inseridos nessas disputas, em um país onde é recorrente a produção institucional do esquecimento dessas lutas. Ainda, recuperar a memória da entidade tornase importante para que as novas gerações de geógrafos se apropriem da história e dos espaços da AGB, trazendo novos significados e perspectivas de ação.

O XIX ENG que aconteceu no mês de julho do ano de 2018 em João Pessoa, suscitou importantes debates nessa direção em seus Espaços de Diálogos e Práticas, nas mesas dos palestrantes e, principalmente, nas ações discutidas pelos Grupos de Trabalho. No entanto, pensamos que essa discussão é ainda insuficiente e, cabe a nós, geógrafos, ampliarmos e reforçarmos a ponte entre as nossas "geografias críticas" e uma Geografia mais atuante.

Para Timo Bartholl, que propõe uma Geografia em movimento:

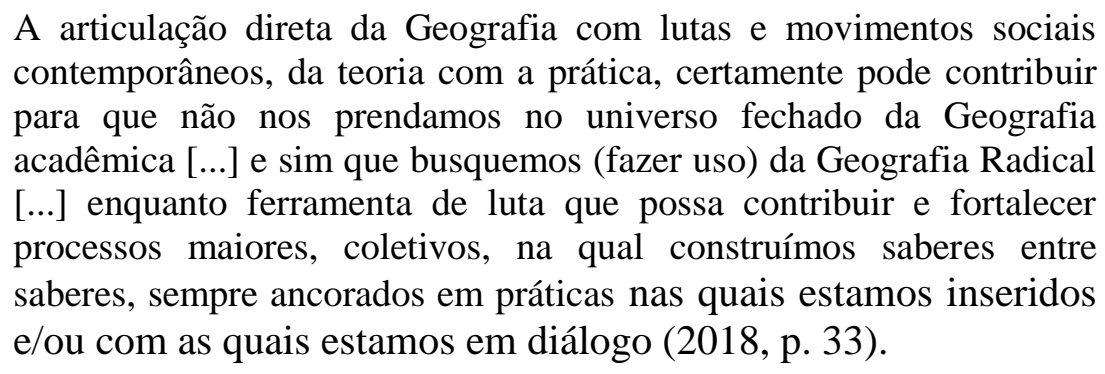

Ainda sobre a análise, buscamos uma perspectiva a contrapelo, ou seja, que procura trazer à superfície os sujeitos das lutas no urbano e que entraram em tensão com o Estado e a classe dominante. Assim, não partimos de um olhar hegemônico sobre o processo, mas do que resiste a ele. Essa forma de análise é colocada por Michel Lowy (2011) a partir da VII tese de 1940 de Walter Benjamin sobre o conceito de História, onde este critica a História da cultura como uma sucessão de feitos gloriosos dos "vencedores". Na perspectiva por ele proposta, a realidade e a lutas de classes não estão separadas e 
aqueles que foram e são oprimidos não são simples objetos de estudo, mas sujeitos da História.

Entre os procedimentos metodológicos utilizados destacamos: levantamentos bibliográficos, entrevistas, pesquisas documentais e pesquisas nos boletins da AGB.

O levantamento bibliográfico buscou temas como a institucionalização da geografia moderna no Brasil; o percurso da geografia urbana; o caminho do IBGE e as práticas de planejamento realizadas pelos geógrafos dentro desse Instituto; a trajetória da AGB e as suas principais reestruturações; as lutas urbanas da década de 1930 a 1980 e a luta pela reforma urbana no Brasil.

As entrevistas foram realizadas com geógrafos que participaram do movimento estudantil de Geografia, como Douglas Santos, atualmente professor convidado na Universidade Autônoma de Madri, razão pela qual a entrevista aconteceu por chamada de vídeo. Também foi entrevistado o professor Diamantino Pereira que leciona na Escola de Artes, Ciências e Humanidades da Universidade de São Paulo, local onde a entrevista ocorreu. Ambos estiveram ligados à transformação interna da AGB em 1978, quando os estudantes se aproximaram da entidade para pensar a Geografia e a sociedade. A professora Arlete Moyses Rodrigues, atualmente professora visitante Universidade Federal da Paraíba, foi entrevistada ainda na fase do projeto para o ingresso no mestrado, mas as contribuições foram muito úteis na construção da pesquisa, já que é uma pessoa fundamental na inserção agebeana na luta pela reforma urbana. O geógrafo Jan Bitoun, que representou a AGB no Conselho das Cidades, órgão Consultivo do extinto Ministério das Cidades, também colaborou com a pesquisa via e-mail, embora o foco de sua atuação tenha ficado de fora do recorte temporal da pesquisa.

Após a qualificação, entrevistamos em São Paulo o professor Eliseu Savério Sposito, professor titular pela UNESP de Presidente Prudente. O professor deu importantes contribuições sobre os Encontros Nacionais da AGB na década de 1970, nos quais esteve presente e relatou sobre os embates entre a geografia quantitativa e a geografia crítica. Por fim, realizamos uma entrevista por vídeo chamada com a professora Maria Adélia de Souza, professora titular de Geografia da USP. A geógrafa atuou fortemente no planejamento urbano/territorial e tem longa formação na área.

As questões realizadas foram abertas e as entrevistas foram do tipo semiestruturada, buscando atingir temáticas importantes para o trabalho, mas dando o 
espaço necessário para a construção das memórias a partir de quem vivenciou os processos. A transcrição das entrevistas baseou-se no método da textualização proposto por José Carlos Meihy e Fabíola Holanda (2010).

A pesquisa de documentos ocorreu na sede da AGB Nacional em São Paulo. Os documentos não estão sistematizados nem catalogados e encontram-se guardados na biblioteca da entidade em várias pastas sobre as prateleiras. No momento de conservar, houve um cuidado em incluir algumas anotações que ajudaram no momento de selecionar os documentos que eram pertinentes à pesquisa. No entanto, essa tarefa foi difícil e só possível com a ajuda do agebeano e funcionário da AGB Caio Alves que com sua experiência, contribuiu muito para que chegássemos até os materiais necessários. Assim, resgatamos correspondências, atas de reuniões, rascunhos, materiais de base e demais documentos que testemunhavam o envolvimento político da AGB nos assuntos da sociedade civil e, sobretudo, da reforma urbana, e selecionamos aquilo que era pertinente dentro do período estudado.

Essa tarefa de pesquisar o arquivo da AGB, além de todas as dificuldades pela falta de uma sistematização dos documentos, nos remete aos desafios colocados de forma muito sensível por Arlette Farge. Segundo a historiadora francesa, confrontar-se como os documentos de um arquivo histórico é estar "tão sozinho como o indivíduo diante da multidão, sozinho e um pouco fascinado. Porque se pressente ao mesmo tempo a força do conteúdo e a impossibilidade de decifrá-lo, a ilusão de reinstituí-lo" (FARGE, 2009, p. 11).

Nesse sentido, as tensões se transformaram em dúvidas na lida com esses documentos: diante de tantos documentos pertinentes à pesquisa e de uma grande vontade em compartilha-los, quais selecionar? Como costurar os registros em um contexto com sentido, sem minimizar a importância e o fascínio por aquelas descobertas e ao mesmo tempo sabendo colocar as limitações dos sujeitos e da entidade envolvida? Foi a partir dessas perguntas que um novo recorte temporal foi definido após o momento da qualificação. Se fosse mantido o recorte inicial, que era até a criação do Ministério das Cidades em 2002, muitos documentos e, portanto, momentos históricos da AGB, não seriam devidamente analisados.

Selecionamos também como materiais dois boletins da AGB para análises das publicações sobre a cidade e o urbano, as quais foram fundamentais para a pesquisa e 
compuseram os três últimos capítulos da dissertação. Tratam-se do Boletim Paulista de Geografia - BPG e o Boletim Carioca de Geografia - BCG. Os dois periódicos estão disponíveis online no site de suas Seções Locais. A escolha das revistas foi feita considerando a importância histórica da Seção de São Paulo e do Rio de Janeiro para a AGB e a localização desses boletins nas duas maiores cidades do país. Além disso e não menos importante, as escolhas foram feitas em função da data de surgimento e da continuidade de publicação das duas revistas, que eram condizentes com o recorte temporal da pesquisa. O BPG vem sendo publicado desde 1949 até os dias atuais, enquanto o BCG teve sua primeira edição em 1948 e em 1982 deixa de ser publicado, sendo substituído pela revista Espaço e Sociedade (ANTUNES, 2008). A leitura desse material proporcionou um maior entendimento do processo da geografia urbana e suas transformações teóricas, possibilitando correlações importantes com a trajetória dos geógrafos e os significados que atribuíram ao espaço urbano e às cidades nos diferentes momentos. Além disso, analisamos também os posicionamentos políticos da AGB expressos no editorial do BPG. Como a organização do BCG era diferente, não tivemos como fazer a análise de editoriais desse boletim.

Por fim é importante destacar que a etapa final de redação do trabalho deu-se em momento crítico de ocorrência da pandemia da covid-19 e decretação da quarentena, o que impossibilitou atividades como pesquisas em bibliotecas e novas buscas documentais, bem como impôs dificuldades de diferentes níveis pela própria delicadeza do momento.

O texto dessa dissertação está estruturado em quatro capítulos. O primeiro, intitulado "A geografia urbana: iniciando o debate" apresenta um panorama da geografia urbana desde o processo de institucionalização da Geografia na década de 1930 até a consolidação da geografia crítica na década de 1980. Fizemos essa sistematização com a finalidade de fornecer subsídios para as discussões e as práticas dos geógrafos analisadas ao longo da pesquisa.

Em seguida, dividimos o recorte temporal da pesquisa em três partes. Muitos geógrafos já traçaram periodizações da trajetória da Geografia no Brasil, levando em conta o processo institucional, as transformações teórico-metodológicas da Geografia e as diferentes fases da AGB, que são determinantes para a compreensão da história dessa ciência no país. Todas essas periodizações foram muito bem sistematizadas por Antunes (2008). No entanto, nossa divisão temporal foi feita de acordo com as momentos da 
geografia urbana e, sobretudo, levando em consideração as publicações analisadas nos boletins do BPG e do BCG. Mesmo assim, entendemos que estabelecer períodos é sempre passível de equívocos e diferentes interpretações, porque em muitos momentos os geógrafos estavam sob a influência de mais de uma vertente teórico-metodológica ou então estavam "subvertendo" a geografia urbana "hegemônica" que estava sendo feita a sua época.

O capítulo dois analisa os processos que estavam acontecendo com os geógrafos tanto na AGB como no IBGE no período de 1934 a 1970 e como a geografia urbana que estava sendo produzida e aplicada a partir desses espaços não dava conta de compreender e nem de intervir criticamente sobre a realidade do país em pleno processo de urbanização e de crescimento das metrópoles e suas periferias. O capítulo três se debruça em entender como as disputas que ocorriam dentro da Geografia e da geografia urbana ao longo da década de 1970 estavam relacionadas e foram influenciadas pela realidade social e política existentes na época: políticas de planejamento em pleno vapor, forte repreensão política, aumento da pobreza nas periferias das grandes cidades e inúmeras lutas por democracia e condições de vida urbana digna. Por fim, o quarto capítulo analisa como, a partir de um amadurecimento da geografia urbana crítica, ocorreu o envolvimento da AGB nas articulações do Congresso Constituinte em 1987, que se deu sobretudo pela sua participação no Movimento Nacional de Reforma Urbana e posteriormente no Fórum Nacional de Reforma Urbana e, no âmbito interno, pela organização de uma Comissão de Assuntos Urbanos. Nesse capítulo analisamos também as limitações da AGB em meio a esse processo, já que muitas vezes as ações eram feitas por alguns profissionais que estavam dentro da AGB e não pela Associação de forma coesa. 


\section{CAPÍTULO 1 - A GEOGRAFIA URBANA: INICIANDO O DEBATE}

Segundo Maurício de Abreu (1994), a cidade dentro do pensamento geográfico mundial tem suas raízes na obra "Anthropogeographie", escrita pelo geógrafo alemão Ratzel em 1890. No entanto, foi somente na década de 1920 que o tema passou a ser tratado de uma forma mais sistematizada tanto pelos geógrafos alemães como pelos franceses. Assim como aqueles, os franceses também optaram por uma abordagem naturalista das cidades, embora estes estivessem preocupados em destacar as "vitórias humanas" sobre o meio natural (ABREU, 1994).

Essa discussão está inserida em um debate mais amplo que trata da origem da geografia moderna, já analisada por muito geógrafos preocupados em compreender a história do pensamento geográfico, cabendo a essa pesquisa apenas entender a sua influência na geografia urbana brasileira.

A ponte entre a pesquisa geográfica urbana na Europa e os estudos do urbano no Brasil se concretizou após a chegada das “missões" europeias que trouxeram a geografia moderna para as recém criadas universidades brasileiras na década de 1930, a Universidade de São Paulo e a Universidade do Distrito Federal, no Rio de Janeiro. Inserido nesse fluxo estava o francês Pierre Monbeig, que escreveu em 1941 "O estudo geográfico das cidades", cujas ideias seriam responsáveis por consagrar um estudopadrão das cidades denominado monografia urbana no Brasil (ABREU, 1994). De acordo com Maurício de Abreu, as monografias são:

[...] o resultado da aplicação do método da Geografia Regional à cidade. Era, na realidade, uma monografia regional, só que a região, neste caso, era a cidade. Assim delineada, o que se poderia esperar então de uma monografia urbana? Nada menos do que uma síntese urbana. E como fazer esta síntese? Da mesma forma como vinham sendo feitas as "sínteses regionais", ou seja, através da integração analítica de dados físicos e humanos, objetivando com isso demonstrar a individualidade deste "fato geográfico" que era a cidade (ABREU, 1994, p. 27).

Para construir as monografias urbanas, era preciso fazer o estudo de seis segmentos: sítio, posição, evolução histórica, fisionomia e estrutura, funções urbanas e o raio de ação da cidade. Embora esses conceitos não tenham sido elaborados por Monbeig, a sua contribuição foi a de proporcionar à geografia urbana brasileira um trabalho metodológico e didático que nortearia diversos trabalhos sobre as cidades brasileiras nas décadas de 1940 e 1950. Muitas monografias não seguiam exatamente as partes propostas 
por Monbeig, configurando-se como monografias urbanas parciais ou monografias regionais com capítulo monográfico urbano (ABREU, 1994).

Como dissemos, a abordagem francesa das cidades adotava uma perspectiva naturalista. Assim, a "população" dentro do método das monografias urbanas era considerada uma fonte de dados mensuráveis e de localização: Qual a composição por idade e sexo? Como se deu numericamente a evolução demográfica? Onde estão os bairros operários e dos mais ricos? (ABREU, 1994).

Nesse sentido, as respostas procuradas não envolviam análises mais profundas dos porquês de tais fenômenos, nem consideravam os processos e os sujeitos inseridos na constituição de cada cidade. Essa geografia urbana, dentro do que ficou conhecido como geografia tradicional, não olhava para a realidade concreta das cidades que surgiam no território brasileiro nas décadas de 1940 e 1950 fruto da industrialização e de outros fatores da dinâmica capitalista presentes no país. Não se debruçavam, portanto, em analisar a desigualdade social que se reproduzia e se materializava cada vez mais no espaço urbano e nem os conflitos e lutas que se desenhavam nesses espaços. Entretanto, apesar da abordagem descritiva, tais trabalhos deixaram contribuições para análise posterior que se fez das cidades, já que traziam dados e informações que são a base de conhecimento histórico sobre o passado das cidades.

A partir do final da década de 1950, embora os estudos baseados nas monografias urbanas tenham continuado, o avanço da urbanização no país que se dava naquele período e que alterava a relação entre cidades e induzia o início de uma formação das regiões metropolitanas, como São Paulo, Rio de Janeiro, Fortaleza, Recife, Salvador, Curitiba, Belo Horizonte e Porto Alegre (SANTOS, 1993), despertou entre os estudos da geografia urbana novos temas e abordagens, como aqueles ligados à metropolização e à área urbano-regional. (ABREU, 1994).

Nesse momento em que se passou a observar a entrada de novos temas nos estudos urbanos, a Geografia brasileira passava um processo de amadurecimento. $\mathrm{O}$ retorno de geógrafos estrangeiros como Pierre Monbeig e também Leo Waibel e Francis Ruellan aos seus países de origem e a participação do Brasil em congressos internacionais, como o realizado em Washington (1952) e no Rio de Janeiro (1956) - o primeiro no Hemisfério Sul -, são indícios desse processo de "autoconfiança" dos geógrafos e geógrafas no Brasil (SCARIM, 2008). 
Nesse sentido, percebemos também o encontro de duas gerações de geógrafos no Brasil (figura 1), o que não representou a eliminação do trabalho e da importância das primeiras gerações. Em São Paulo, a primeira geração (de Aziz Ab’Saber, Nice Lecocq Muller, Pasquale Petrone, Léa Goldestein, Ary França, De Martonne, Pierre Monbeig, Maria da Conceição Vicente Carvalho, entre outros) entra em contato com a segunda geração (de Manoel Gonçalves Seabra, Judith de La Corte, Rosa Ester Rossini, Armem Mamigonian, entre outros). No Rio de Janeiro, a primeira geração (de Orlando Valverde, Nilo Bernardes e Lysia Bernardes, Carlos Augusto Figueiredo Monteiro, Maria Therezinha de Sagadas Soares) se depara com a segunda geração (Roberto Lobato Corrêa, Speridião Faissol, Bertha Becker, Therezinha de Castro, Antônio Teixeira Guerra, além de outros) (SCARIM, 2008).

Esses novos horizontes de estudo da geografia tradicional que se ampliaram na década de 1960 alimentaram e foram alimentados pelas atividades de planejamento que eram desenvolvidas no interior do IBGE, cujo trabalho dos geógrafos era muito importante. Naquele período, com as mudanças no território brasileiro cada vez urbanizado, eram necessárias novas metodologias para as políticas de regionalização e para a elaboração dos planos de governo produzidos durante o regime militar. O que se observou foi que a geografia urbana estava amadurecida o suficiente para contribuir com aquelas necessidades.

Os estudos das redes urbanas foram uma das bases para as ações em planejamento que foram feitas no IBGE ao longo da década de 1960, tornando-se ainda mais importantes após o golpe militar. Os geógrafos franceses Michel Rochefort, que se aproximou do IBGE após o Congresso no Rio de Janeiro de 1956, e Jean Tricart, foram as grandes inspirações para esses estudos que passaram a ser feitos no Brasil (ALMEIDA, 2002). De acordo com Abreu:

A perspectiva de que, a partir da cidade, poder-se-ia intervir no quadro regional, alterando-o, acabou por dar à Geografia um sentido de aplicabilidade que nunca tivera antes. Planejamento, Geografia ativa, Geografia aplicada, Geografia voluntária.... Eis, agora, as novas dimensões da Geografia, que abriram novos horizontes aos geógrafos (ABREU, 1994, p. 40).

A formação das metrópoles também foi alvo de estudos a partir daquele momento, tanto a partir de suas funções regionais como de sua organização interna (ABREU, 1994). Na década de 1970, esses estudos também passam a fazer parte de uma geografia 
aplicada, subsidiando a criação pelo governo militar das nove regiões metropolitanas no Brasil citadas acima.

Figura 1 - Transição de geógrafos de SP e RJ na década de 1950

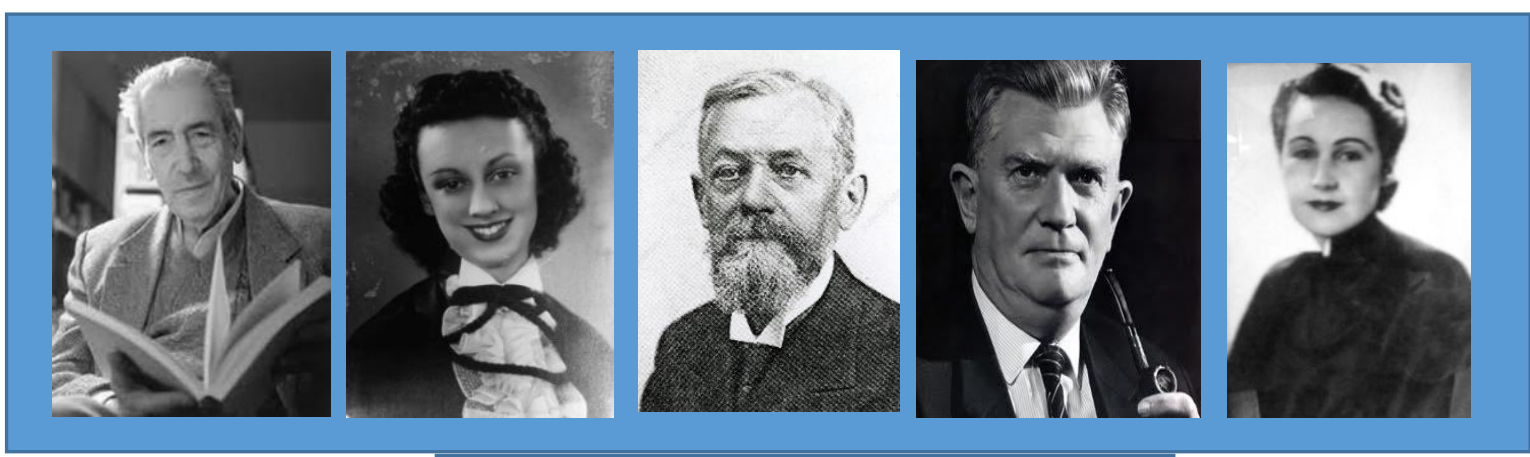

Acima, da esquerda para a direita: Aziz Ab'Saber, Nice Lecoq Muller, De Martonne, Pierre Monbeig, Maria da Conceição Vicente Carvalho.

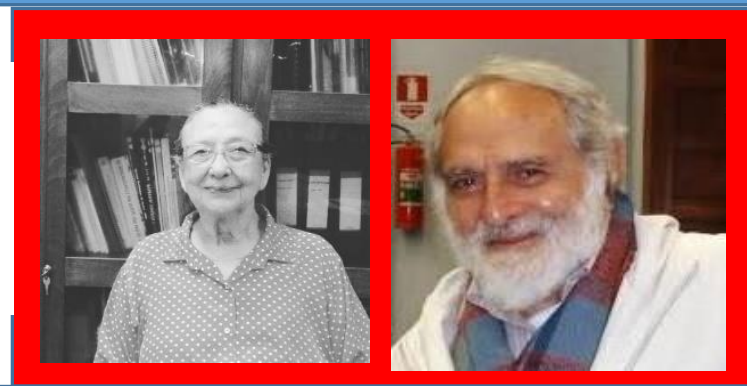

À esquerda, da esquerda para a direita: Rosa Ester Rossini, Armen Mamigonian.
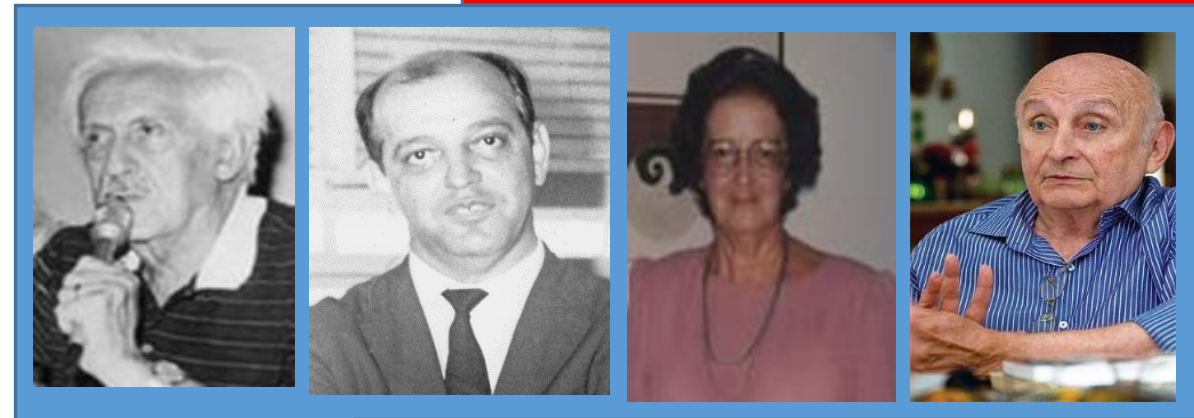

À esquerda, da esquerda para a direita: Orlando Valverde, Nilo Bernardes, Lysia Bernardes, Carlos A. Figueiredo Monteiro.

À direita, da esquerda para a direita: Roberto Lobato Correa, Bertha Becker, Therezinha de Castro, Antônio T. Guerra.

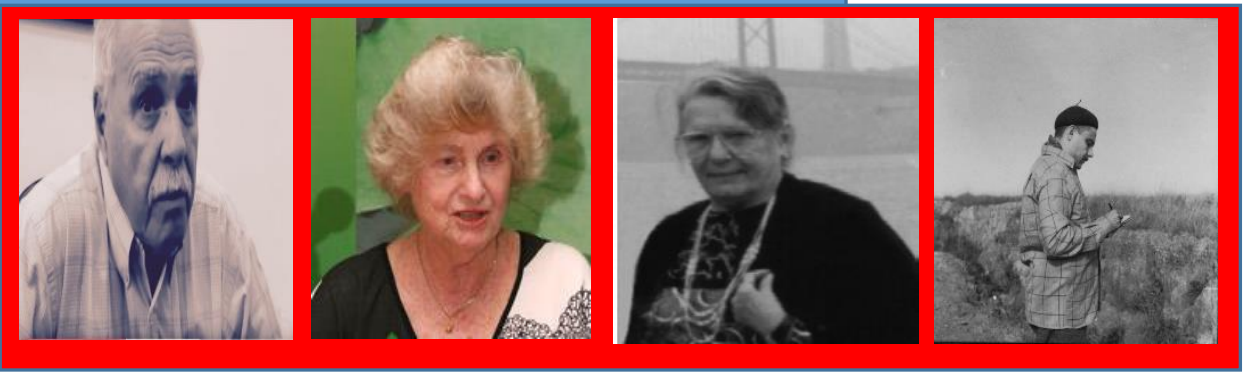

Elaborado pela autora.

Ao longo de todo esse período que ficou "sob o guarda-chuva" da geografia tradicional, é preciso citar também os estudos urbanos que conseguiram romper o viés descritivo herdado das monografias urbanas, sem também pisar na seara da geografia aplicada. São estudos bastante inovadores que mostram relações, fluxos e processos. É o caso, por exemplo, de Milton Santos (foto 1), que já na década de 1960 estava preocupado em entender as cidades dos países subdesenvolvidos (ABREU, 1994). 


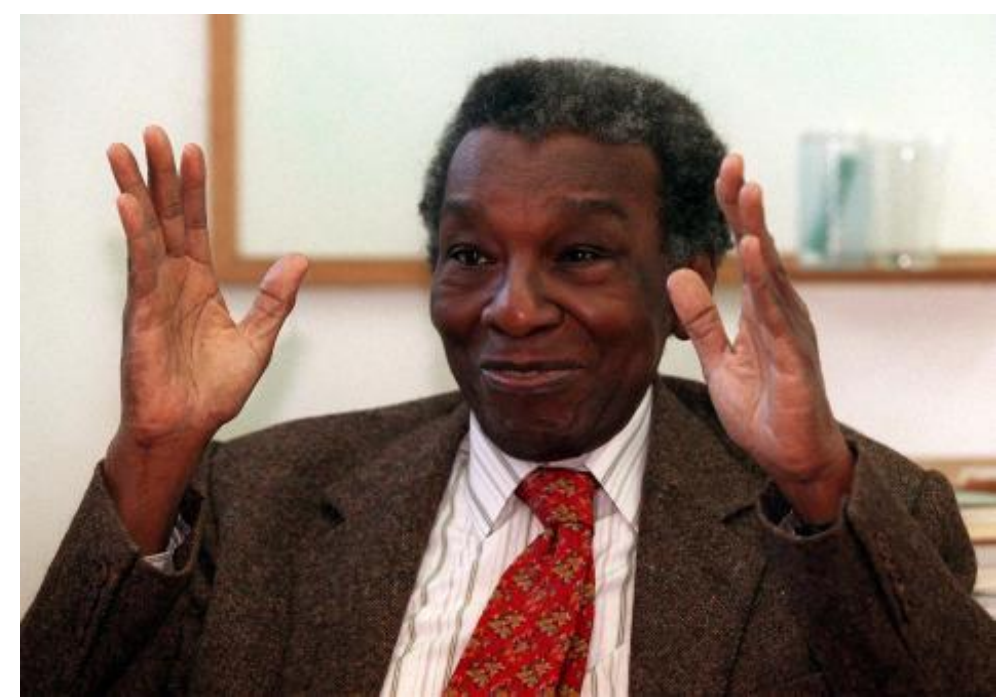

Foto 1: Geógrafo Milton Santos. Fonte: Site da Revista Movimento.

De uma maneira geral, podemos dizer que até meados da década de 1960, a geografia urbana produzida no Brasil tinha como principal base de inspiração a geografia francesa, seja para a produção de monografias seja para o estudo das redes urbanas. A partir desse momento e, sobretudo a partir dos anos 1970, novas abordagens são somadas à Geografia brasileira, que passa por um duplo processo de renovação. Uma dessas frentes de renovação era a geografia pragmática, que tinha sua origem nos EUA e no Reino Unido, e que passou a ser chamada de geografia quantitativa (ABREU, 1994; MORAES, 2007).

Apesar “de não ter sido por obra e graça da 'quantitativa' que a vinculação da Geografia com o planejamento se realizou no Brasil"'(ABREU, 1994, p. 44), essa vertente esteve muito presente nas atividades de planejamento realizadas nos órgãos oficiais do governo, como o IBGE. A vinda do economista e planejador John Friedmann, do geógrafo britânico John Cole e do estadunidense Brian Berry para dar cursos nessas instituições foi fundamental para que essa nova roupagem fosse adotava pela Geografia brasileira e pelo planejamento (ALMEIDA, 2002; BONFIM, 2007).

A geografia quantitativa foi considerada muito favorável ao planejamento por ter uma linguagem próxima das outras “matrizes científico-planejadoras”, como a Economia. Ao mesmo tempo colocava elementos novos como contribuição, como a capacidade de analisar o território, que foi fundamental para as políticas de planejamento do governo militar (ABREU, 1994; BONFIM, 2007).

Nesse sentido, a maior parte dos estudos da geografia urbana produzida na época à luz da geografia quantitativa foi a nível territorial/interurbana. No entanto, também 
foram feitos estudos intraurbanos e que tinham como objetivos apontar padrões de distribuição de fenômenos no espaço urbano, mostrando uma série de dimensões que nem mesmo a superposição dos mapas revelaria, somente os novíssimos computadores que começaram a ser utilizados. O uso das máquinas e o acesso aos dados dos Censos aplicados no Brasil colocaram os geógrafos do IBGE como grandes produtores de trabalhos baseados na geografia quantitativa, influenciando bastante a pesquisa em geografia urbana na UFRJ, além da UNESP de Rio Claro (ABREU, 1994; ALMEIDA, 2002).

A geografia pragmática/quantitativa fazia apenas uma crítica à insuficiência da análise tradicional, sem questionar seus fundamentos e a sua base social. Segundo os adeptos da geografia pragmática, a geografia tradicional falava do passado, sendo um conhecimento de situações já superadas e por isso inoperante como instrumento de intervenção na realidade (MORAES, 2007). Ainda de acordo com Moraes:

Nessa atualização do discurso burguês a respeito do espaço, que se poderia chamar de renovação conservadora da Geografia, ocorre a passagem, ao nível da disciplina, do positivismo clássico para o neopostivismo. Troca-se o empirismo da observação direta (do ater-se aos fatos) ou dos "levantamentos dos aspectos visíveis" pela estatística ("das médias, variâncias e tendências"). Do trato direto com o trabalho de campo, ao estudo filtrado pela parafernália da cibernética (MORAES, 2007, p. 110).

Nesse sentido, Abreu (1994) aponta que a geografia quantitativa não superou totalmente a geografia tradicional, somente o fez no discurso, mas na prática continuava a se dedicar à busca por padrões espaciais, sem chegar a nenhuma generalização ou lei, com a diferença de ter a seu favor os avanços da cibernética. Essa Geografia entra em crise ao mesmo tempo que o regime militar também se encaminha para o fim, levando consigo o próprio sistema de planejamento (ABREU, 1994).

Concomitante à geografia quantitativa, surgia ao longo da década de 1970 outra vertente do movimento de renovação do pensamento geográfico. Essa frente agrupava o conjunto de propostas que se pode denominar geografia crítica. De acordo com Moraes (2007), tanto a geografia crítica como a geografia pragmática faziam parte de um movimento de renovação da Geografia considerada tradicional, que tinha suas bases na geografia regional de matriz francesa, sobretudo inspirada em Paul Vidal de La Blache.

Esta denominação vem de uma postura crítica radical frente à Geografia existente (seja a tradicional ou a pragmática) e, mais ainda, de uma postura frente à realidade. São 
autores que se posicionam por uma transformação da realidade social e assumem o conteúdo político do conhecimento científico (MORAES, 2007). De acordo com Abreu (1994, p. 53), foi uma forma de "ver o que se escondia atrás da paisagem visível da Geografia Tradicional, sem entretanto fazê-lo com o auxílio dos óculos da Geografia Neopositivista".

A geografia crítica tem suas raízes na ala mais progressista da geografia regional francesa ${ }^{1}$. Isso se deu em função da crescente importância do elemento humano, que aparece na diferenciação entre meio e meio geográfico; na sujeição da Geografia Física à Humana e na ideia de região como produto histórico. Assim, a geografia regional francesa aproximou-se da História e da Economia levando à introdução de novos elementos na análise regional e originando as primeiras manifestações de um pensamento geográfico crítico (MORAES, 2007).

A primeira manifestação que mais se destacou dentro dessa renovação crítica foi a proposta da Geografia Ativa, nome de um livro escrito por P. George, Y. Lacoste, B. Kayser e R. Guglielmo. Do mesmo modo que o livro "A Geografia serve, antes de mais nada, para fazer a guerra" foi a crítica mais contundente à geografia tradicional, escrito por Yves Lacoste (MORAES, 2007).

Elisa Verdi (2016) faz um longo resgate em sua dissertação de mestrado de como a Geografia, em vários países, foi introduzindo elementos de crítica e de análise da realidade social. Retomando Peet (1982), a autora coloca que foi a partir de David Harvey que a Geografia tida como radical passa a ser sinônimo de uma geografia marxista nos Estados Unidos. No Brasil, uma das perspectivas desse movimento de renovação se reivindicava marxista, sendo a concepção que mais marcou a geografia crítica por seu forte sentido de ruptura (ABREU, 1994).

Em termos teórico-metodológicos, o materialismo histórico fundamentou para essa corrente uma nova concepção de espaço, que não é organizado pela sociedade, mas produzido por ela através do trabalho, num processo que é ao mesmo tempo histórico e social, ou seja, que tem em cada momento uma determinada configuração nas relações de classe (VERDI, 2016; ABREU, 1994).

\footnotetext{
${ }^{1}$ De acordo com Moraes (2007), a figura de Jean Dresch é uma antecipação desse movimento na década de 1930 e 1940 com o seu discurso político crítico.
} 
Além da perspectiva marxista, outras perspectivas vão se desenhando dentro da geografia urbana considerada posteriormente como crítica, como aquelas que possuíam um embasamento neoliberal ou as que tinham apenas um caráter de denúncia, sem grandes aprofundamentos teórico-metodológicos. O que havia em comum era o pressuposto de que a cidade e a prática social são interdependentes entre si, além do compromisso com a transformação da sociedade que se estuda (ABREU, 1994). Entre essas diferentes abordagens que se deram ao longo das décadas de 1970 e 1980, citamos alguns autores pioneiros em olhar para o urbano com a lupa da geografia crítica de acordo com Abreu (1994). É o exemplo de Ariovaldo Umbelino de Oliveira (1978); Ana Fani Carlos (1979); Paulo Cesar Xavier Pereira (1982), Armando Correa da Silva (1982), Milton Santos (1979; 1982), José Antônio Rochenzel (1985), Arlete Moyses Rodrigues (1988). Importante também falar do projeto coletivo de pesquisa, realizado a partir de 1977 por Arlete Moysés Rodrigues, Myrna T. Rego Vianna e Regina Célia Bega dos Santos,

[...] que pretendeu estudar o processo de apropriação e consumo do espaço urbano a partir da sua vinculação com o processo migratório (Rodrigues, 1980, 1981 e 1982; Vianna, 1980 e 1982; Santos, 1980 e 1983) (...). Essas geógrafas propuseram-se a repensar a questão da habitação nas cidades brasileiras, descartando, de antemão, as explicações que pretendiam atribuir o "caos urbano" simplesmente às migrações ou à crise da habitação. Ao contrário, a partir de um estudo minucioso, que acompanhou a trajetória de diversos migrantes desde seus locais de origem até à favela ou loteamento de periferia em que estavam residindo, elas puderam recuperar todo um processo de transformação de relações de produção e de trabalho ocorrido no Brasil pós-1950, processo esse que estava por trás do ato de migrar, e chamaram atenção, ademais, para a verdadeira luta travada por esses indivíduos para se manter no mercado de trabalho paulistano e para apropriar-se de um pequeno pedaço de chão (ABREU, 1994, p. 62).

Nesse sentido, esses geógrafos citados foram precursores da geografia urbana crítica no Brasil consolidada ao longo da década de 1980. Entendiam que não era mais possível analisar a cidade e o urbano com a lupa da geografia tradicional e do planejamento. Havia uma necessidade de compreender os problemas urbanos no país e sobretudo nas periferias das metrópoles, como a falta de moradia, a dificuldade do transporte, a ausência de creches, serviços de saúde, asfalto, iluminação etc., associandoos a processos e totalidades. Era preciso considerar as lutas organizadas que aconteciam nesses espaços reivindicando melhores condições de vida e todas as demandas de uma sociedade em transformação. 
Mais do que precursores da geografia urbana crítica, alguns desses mesmos geógrafos citados vão se engajar em colocar a Geografia como uma ciência capaz de contribuir com a classe trabalhadora, entendendo que era preciso atuar para além dos espaços das universidades e do IBGE. A AGB, que havia sido palco para a geografia crítica, ganha força no final da década de 1970, o que representou uma resposta encontrada por esses geógrafos para atuar junto à sociedade e aos movimentos sociais urbanos. 


\section{CAPÍtULO 2 - ORIGENS DA AGB E O PENSAMENTO EM GEOGRAFIA URBANA (1934-1970)}

A institucionalização da geografia moderna no Brasil tem como um dos marcos fundamentais a criação, em 1934, da Universidade de São Paulo e da sua Faculdade de Filosofia, Ciências e Letras, onde começa a ser oferecido o curso de Geografia e História. No ano seguinte, na cidade do Rio de Janeiro, esse curso é implementado na recém-criada Universidade do Distrito Federal, que depois passa a ser nomeada Universidade do Brasil.

A criação dos cursos de Geografia, tanto em São Paulo como no Rio de Janeiro, teve uma grande influência das diversas "missões" que chegaram ao Brasil na década de 1930, sobretudo as francesas, ora contratadas por aqueles que estavam no governo, ora por integrantes da elite econômica regional que queriam se alinhar com aquilo que era “moderno" e "ilustrado" (ANTUNES, 2008; PEIXOTO, 1995; ZUZMAN, 2001).

Além dos cursos universitários, a geografia moderna no Brasil tem como pilares a criação da Associação dos Geógrafos Brasileiros - AGB (1934), do Instituto Brasileiro de Geografia e Estatística - IBGE (1938) e do Conselho Nacional de Geografia - CNS (1937). Importante ressaltar que, no momento de criação dessas novas instituições, o ensino de Geografia já estava presente nos currículos das escolas ${ }^{2}$, sendo o quadro de professores formado por profissionais de outros campos do conhecimento. Essa demanda pela formação de professores de Geografia no ensino secundário também representou um impulso para esse processo de institucionalização da ciência (ROCHA, 1994).

Entre os docentes franceses organizados em missão que vieram lecionar na Faculdade de Filosofia, Ciências e Letras da USP estava Pierre Deffontaines, que seria responsável pela cadeira de Geografia Física e Humana do curso de Geografia e História, sendo substituído no ano seguinte por Pierre Monbeig após se mudar para o Rio de Janeiro para contribuir com a fundação da UDF (SEABRA, 2008).

A criação da Associação dos Geógrafos Brasileiros se deu já no primeiro ano de fundação da USP, sendo Deffontaines e mais três intelectuais brasileiros - Caio Prado Junior $^{3}$, advogado e aluno do primeiro ano do Curso de História e Geografia; Rubens

\footnotetext{
${ }^{2}$ Nesse sentido, Abreu (1994) coloca que a introdução da geografia moderna não foi um fenômeno totalmente novo com a fundação da USP. O geógrafo francês erradicado no Brasil, Delgado de Carvalho, já havia tentado adequar o currículo do Colégio Pedro II - RJ à geografia francesa no início do séc. XX.

${ }^{3}$ Caio Prado Jr., líder da Aliança Libertadora Nacional - ALN, esteve preso de 1935 e a 1937, num contexto de autoritarismo do governo Vargas. Muito atuante nas atividades da AGB, sua prisão foi uma das principais dificuldades no início da trajetória da entidade (SEABRA, 2008).
} 
Borba de Moraes ${ }^{4}$, escritor e bibliógrafo e Luiz Flores de Moraes Rego, geólogo e catedrático do curso de Geologia e Mineralogia da Escola Politécnica da USP - os responsáveis por esse feito (SEABRA, 2008).

$\mathrm{Na}$ ata de fundação da AGB, constava como finalidades da entidade: 1) reuniões periódicas dos membros, com exposição de um assunto de Geografia brasileira; 2) organização de excursões em comum para o estudo de uma questão e 3) constituição de uma biblioteca especializada em Geografia e fichários (SEABRA, 2008). Nota-se que, no documento de fundação, o papel da AGB era o de produção e valorização dos conhecimentos científicos, processo que realmente aconteceu e teve grande importância para a institucionalização da Geografia no Brasil. Nas palavras de Nice Lecoq Muller (1961, p.48), a AGB era a "Peregrina da Boa Nova: a Geografia Moderna".

Zuzman (2001) põe em evidência o caráter elitista da criação da USP e da AGB, já que a elite paulistana via na educação um passo importante para se colocar em evidência no país no contexto vivido na década de 1930. A autora coloca que a elite de São Paulo integrava as reuniões da AGB, como Júlio de Mesquita Filho, diretor do "O Estado de São Paulo" "5; o diretor da Faculdade de Filosofia, Ciências e Letras, Alfredo Ellis Júnior; e o industrial ligado à Escola Superior de Sociologia, Roberto Cochrane Simonsen.

Além de possuir um caráter elitista, a AGB dos anos inicias tinha como parâmetro as associações francesas, o que significa dizer que a organização interna, os problemas e a forma como estes problemas eram tratados foram trazidos da geografia francesa. Assim, essas condições podem ter influenciado na distância que a Geografia brasileira manteve incialmente de temas como a geopolítica, o papel do Estado, as ações reivindicativas da população, entre outros (VIEIRA; PEDON, 2004).

Entre 1934 e 1945, a AGB teve uma atividade restrita aos estados de São Paulo e do Rio de Janeiro, embora geógrafos do Paraná também participassem de alguns encontros. Durante esse tempo, suas atividades deram-se, principalmente, dentro da USP e no interior do Conselho Nacional de Geografia (CNG), onde os geógrafos cariocas se encontravam (ANTUNES, 2008).

\footnotetext{
${ }^{4}$ Rubem Borba de Moraes estudou em Paris. Não apenar os franceses vieram para o Brasil naquele período, como os intelectuais da elite brasileira iam estudar na França (ANTUNES, 2008).

${ }^{5}$ E espécie de mecenas da missão francesa (ZUZMAN, 2001).
} 
A AGB passou a atuar em escala nacional e aumentou a comunicação com o restante do país a partir de $1945^{6}$. Essa mudança veio com a elaboração de um novo estatuto que, entre outras medidas, unificava a entidade e criava as Seções Regionais (figura 2). Deste momento até a década de 1970, a AGB deixa de ser uma entidade paulista para tornar-se uma entidade nacional com as suas devidas proporções. Assim, no período compreendido entre os anos de 1945 e 1970, período entre duas importantes reformas estatutárias, a AGB passou a ter seis seções regionais: São Paulo, Rio de Janeiro, Paraná, Minas Gerais, Pernambuco e Bahia (ANTUNES, 2008.).

Nesse período também (1946-1969) foram criadas as Assembleias Anuais, importantes momentos dos geógrafos da AGB que consistiam em "reuniões anuais nas quais os geógrafos brasileiros se encontravam para apresentar comunicações, trocar experiências e, principalmente, para fazer trabalhos de campo em conjunto" (ABREU, 1994, p. 33).

As Assembleias Anuais merecem um destaque pela importância que o trabalho de campo assumiria nas atividades de pesquisa dos geógrafos, valor ainda muito presente nos dias de hoje. As reuniões se davam em torno dessas pesquisas em campo, ou seja, estas estavam totalmente integradas às discussões que eram feitas nas Assembleias. De acordo com Abreu (1994), era uma forma coerente com a proposta empirista que norteava a Geografia brasileira na época.

Mais à frente, em 1970, a AGB tem uma nova reformulação de estatuto ${ }^{7}$, conforme costa na figura 2, e uma das principais mudanças que vem com o novo regimento foi a substituição das Assembleias anuais pelos Encontros Nacionais de Geografia - ENGs, que aconteceriam a cada dois anos.

\footnotetext{
${ }^{6}$ Até 1945, existiam doze cursos de graduação em Geografia no país, o que facilitou a difusão da AGB pelo território (ANTUNES, 2008).
} 
Figura 2 - Principais reformas estatutárias da $\mathrm{AGB}^{8}$

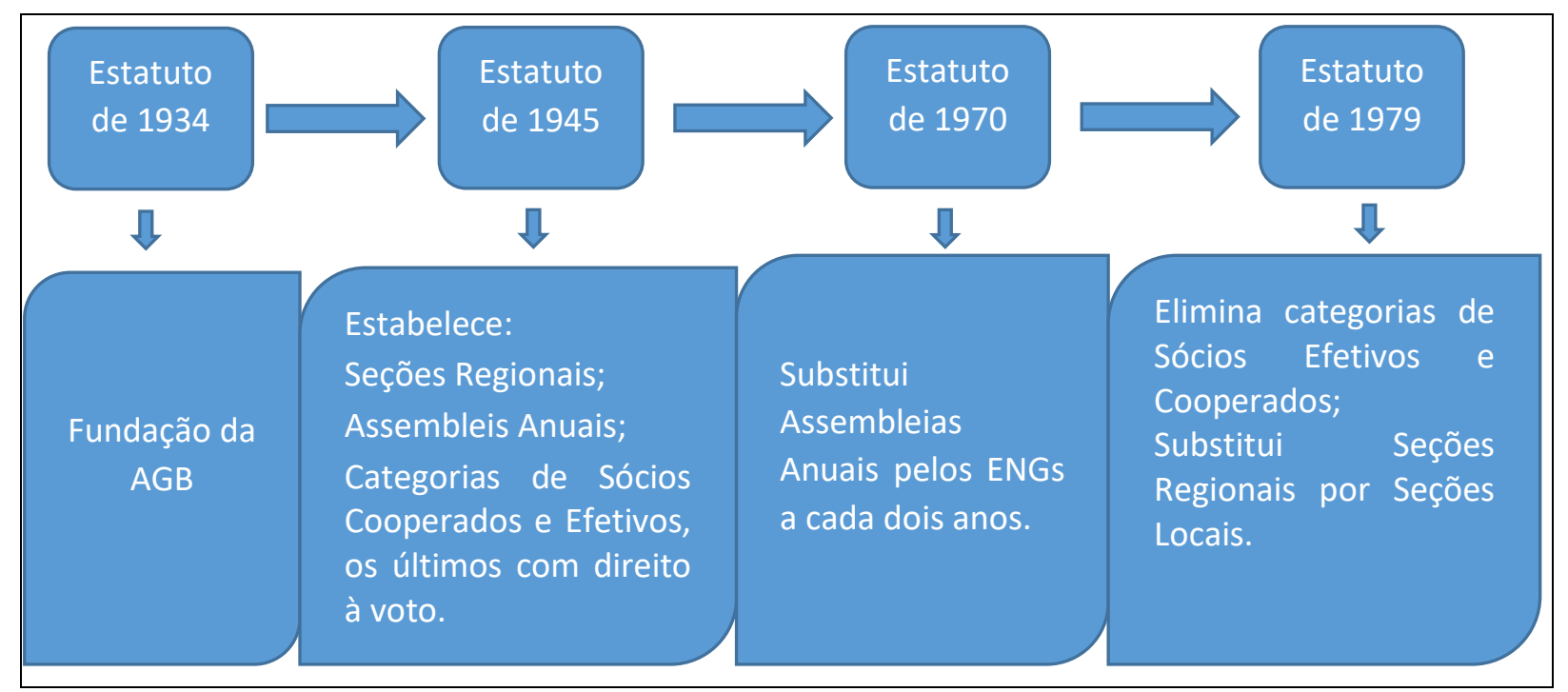

Elaborado pela autora baseado na tese de Charlles da França Antunes (2008).

A importância dos ENGs para a Geografia será analisada no próximo capítulo. Os ENGs que aconteceram em sua primeira década de existência estavam inseridos dentro um contexto de ditadura do regime militar, quando havia uma forte vigilância nos espaços de militância e das universidades. Os Encontros de 1972 e de 1976 continuaram refletindo as características iniciais da AGB, de forte hierarquização, de grande valorização da produção do conhecimento científico aliado aos imensos esforços no estudo do território e de discussão de uma Geografia que também podia interessar aos sujeitos da classe dominante. No entanto, de acordo com os depoimentos de geógrafos que estiveram presentes nestes eventos, mesmo nesses primeiros Encontros já era possível observar discussões entre diferentes abordagens teórico-metodológicos, com cada vez mais espaço para a chamada geografia crítica, apesar da presença de uma forte censura e vigilância nesses eventos.

Como também veremos adiante, em 1979 aconteceria mais uma mudança de estatuto, refletindo o movimento de tensões e debates transcorridos ao longo da década de 1970. Nesse momento de muitos conflitos sociais, a geografia crítica assumiria um papel importante diante do imperativo imposto aos geógrafos de analisar criticamente a sociedade e o espaço e de se posicionar diante das injustiças e da desigualdade social que estavam postas.

\footnotetext{
${ }^{8}$ Não foi incluído no quadro a reforma de estatuto de 1936.
} 


\subsection{Urbanização, crescimento das metrópoles e conflitos urbanos}

A expansão das Seções Regionais pelo território brasileiro acontece em meio a um processo mais amplo de urbanização que ocorria em todas as regiões do país naquele período. Milton Santos (1993) aponta como um dos elementos que levaram ao avanço da urbanização no território brasileiro o aumento do letramento da população, que consequentemente elevou a diversidade da terciarização e, portanto, da lógica urbana.

A partir da década de 1930, e sobretudo na década de 1940, a cidade de São Paulo vai se destacar como "área polar do Brasil", ou ainda como a "metrópole onipresente" (SANTOS, 1993), ultrapassando o papel desempenhado pela cidade do Rio de Janeiro. Seu crescimento e sua importância estavam associados à presença da indústria que se instalava no município e na região limítrofe do $\mathrm{ABC}$, mas também por toda a informação que passou a ser produzida ou coletada, não apenas para uso interno, mas voltada para todo o território nacional, de acordo com os interesses dos sujeitos da metrópole paulistana (op. cit.).

Nesse sentido, a amplificação do fenômeno da urbanização, que no Brasil está ligado a à fatores como a industrialização e à terciarização, leva ao aumento da metropolização, cujos objetos - as regiões metropolitanas - serão adotadas como regiões de planejamento na década de 1970 (SANTOS, 1993).

Em seus primeiros anos de existência a entidade olhava para essas transformações com a lupa da geografia tradicional. Assim, havia uma grande preocupação em descrever os espaços e organizar monografias detalhadas sobre cada local, pontuando aspectos naturais e sociais. A partir da criação do IBGE em 1937 e da forte participação de geógrafos em suas atividades, o olhar sobre o urbano passava também pelo filtro do planejamento, o que repercutiu na universidade, nas Assembleias Anuais da AGB e nas publicações dos boletins da AGB, sobretudo no Boletim Carioca de Geografia.

As monografias urbanas, apesar de serem ricas produções de conhecimento, não tinham como objetivo e não davam conta de evidenciar os conflitos de classe que ocorriam pelo território brasileiro, cada vez mais urbanizado, nem de expor as contradições que estavam postas na produção desse espaço urbano. Além disso, não captavam debates importantes que estavam sendo feitos, como o início da discussão sobre a reforma urbana no Brasil. 
Nesse período de avanço da urbanização no Brasil, há uma reestruturação dos sujeitos que atuam no país. Destacam-se as elites industriais, que passam a disputar o espaço político com as forças existentes, como a aristocracia agrária e os grupos ligados aos setores externos. Consolidam-se também o setor operário e as massas urbanas, que entram na disputa pela melhoria das condições de trabalho e de vida no espaço urbano. A tarefa de costurar todos esses interesses coube ao grupo liderado por Getúlio Vargas, que implantou no decorrer da década de 1930 uma forte centralização política, culminando em 1937 com o Estado Novo (ARAVECCHIA-BOTAS, 2016).

Nesse contexto, o Estado passou a fazer uma série de intervenções, como a criação do IBGE e do Conselho Nacional de Geógrafos, analisados a seguir, que iriam no caminho de suprir as necessidades de caráter territorial do governo, num contexto de grande fragmentação do território brasileiro.

Muitas ações realizadas representavam conquistas dos trabalhadores, mas que estavam ao mesmo tempo imbricadas de uma lógica autoritária e de uma racionalidade econômica baseada na indústria: a criação dos sindicatos oficiais e a fundação do Ministério do Trabalho, Indústria e Comércio em 1930, que se insere na disputa ideológica pelo controle das organizações sindicais; a integração dos trabalhadores urbanos com a criação da Consolidação das Leis de Trabalho (CLT); os institutos de previdência que vieram para consolidar a transformação do modelo previdenciário por empresa para o modelo de categoria profissional, mantendo distantes as reivindicações dos trabalhadores (ARAVECCHIA-BOTAS, 2016).

A questão habitacional também foi alvo de intervenções, refletindo as mudanças que o país enfrentava naquele momento e a falta de moradias para as pessoas mais pobres. Segundo Ronchezel, a explicação para essa insuficiência vai além da industrialização em si:

[...] não foi a industrialização que engendrou a insuficiência de moradias para os pobres. Porém, na forma como ela se deu no Brasil, concentrada e centralizada, fez desencadear, simultaneamente às transformações sociais que foram ocorrendo no campo, um imenso fluxo migratório de população convergindo principalmente para São Paulo. Desencadeou-se, também, um crescimento da cidade, cuja ordem jamais emanou de objetivos de uma política de atendimento das necessidades básicas da população (RONCHEZEL,1986, p. 9).

Nesse cenário que começou a ser produzido nas cidades, as ações políticas que foram feitas para diminuir a falta de moradias foi a criação das Carteiras Prediais dos Institutos 
de Aposentadoria e Previdência (1938), a aprovação da Lei do Inquilinato (1942) e o Decreto-lei 58 de 1938, que regulamentou os loteamentos populares, garantindo a que os terrenos fossem adquiridos à prestação. Mais à frente, já no governo Dutra em 1946, houve a inauguração da Fundação Casa Popular (BONDUKI, 1994).

No entanto, no período que vai de 1937 a 1964, é baixo o número de unidades habitacionais produzidas pelos Institutos de Previdência e Fundação Casa Popular frente às necessidades habitacionais ${ }^{9}$. Mesmo assim, era importante mostrar que se fazia algo nesse setor e que o Estado pela primeira vez assumia um compromisso com as moradias dos trabalhadores. É importante também lembrar que esse processo não aconteceu sem pressão da classe trabalhadora e que dessas ações é produzido um conhecimento técnico que vai alimentar novas discussões sobre a questão habitacional em momentos futuros ${ }^{10}$ (BONDUKI, 1994; ARAVECCHIA-BOTAS, 2016).

As ações do Estado na área da habitação vieram em um contexto em que os cortiços eram, desde as últimas décadas do século XIX, a forma de moradia mais comum entre os trabalhadores, chegando a representar um terço das habitações existentes em São Paulo e abrigando a maioria da população. Não eram apenas casarões adaptados, já que os cortiços viraram um tipo de negócio e muitas casas foram construídas do zero. O caso mais célebre é o conde D'Eu, genro de D. Pedro II, assim denominado "Conde Cortiço" (BONDUKI; 1994; ANT, KOWARICK, 1994).

A divisão de uma casa em um maior número possível de cubículos era conveniente para a acumulação industrial, mantendo a reprodução da classe trabalhadora a baixos custos. As condições dos trabalhadores eram de salários baixos, precariedade, acidentes e jornadas de trabalho frequentemente de quatorze horas ou mais. Havia também uma grande utilização do trabalho infantil (ROLNIK, 1994).

As vilas operárias, por outro lado, tinham melhores condições para se habitar. Além disso, construir uma vila ao lado de uma fábrica quando não se tinha um amplo exército de proletários era vantajoso para os empreendedores. O fato de haver uma população "garantida" para o trabalho e que na possibilidade de perda do emprego perderia também

\footnotetext{
${ }^{9}$ Entre 1946 e 1950, os IAPs e a FCP produziram o maior número de habitações, comparado ao de outros governos até 1964 (ARAVECCHIA-BOTAS, 2016).

10 Nilce Aravecchia Botas em "Estado, Arquitetura e Desenvolvimento" (2016) analisa a atuação dos arquitetos e engenheiros no Iapi.
} 
a casa era outra vantagem. Na cidade de São Paulo, o Conjunto Matarazzo e o Bairro Maria Zélia no Belém são testemunhos dessas iniciativas (RONCHEZEL, 1986).

No entanto, a amortização de um capital que não era investido diretamente na produção e também os riscos em concentrar operários em um mesmo espaço num momento em que o sindicalismo brasileiro se fortalecia, fez com que poucas vilas foram erguidas e as poucas feitas eram pensadas para os trabalhadores mais especializados (ROCHEZEL, 1986).

Entre as vilas operárias e os cortiços, criou-se uma certa oposição ideológica, porque passaram a representar no imaginário da época os trabalhadores e os perigosos marginais, respectivamente. Esse preconceito que recaía sobre todos os moradores dos cortiços vinha acompanhado da ideia de que cortiços eram sujos e promíscuos. Uma das repercussões foi a criação da Polícia Sanitária na última década do século XIX, que podia invadir e vasculhar essas casas. As pessoas febris eram levadas para o Hospital do Isolamento, os casos de "loucuras" para o Hospital dos Alienados e os criminosos para o Presídio ou para o Instituto Domiciliar (ROLNIK, 1994).

Nas primeiras décadas do século XX, ocorreram vários tipos de revoltas no espaço urbano. Eram comuns lutas urbanas contra os planos de "limpeza" do poder público sobre determinadas regiões que eram consideradas insalubres e "perigosas" para a ordem pública. Sob a influência das ideias anarquistas que vieram com os imigrantes italianos e espanhóis, surgiu o primeiro movimento operário em São Paulo, lutando pela melhoria das condições de trabalho nas fábricas. Nos bairros, estes propunham as "ligas inquilinas", movimentos de boicote ao pagamento dos alugueis, despesa que sobrecarregava o orçamento dos trabalhadores (ROLNIK, 1994; BONDUKI; 1994).

Após a ascensão do Getúlio Vargas, o Estado “chama para si” a responsabilidade e a questão dos alugueis também vai sofrer uma intervenção. Diante dos alugueis cada vez mais caros e da luta da população pela redução desses valores, o governo estabeleceu o decreto da Lei do Inquilinato em 1942, ou seja, passou a fazer o controle dos valores locativos. Tal medida não era simplesmente uma resposta às reivindicações dos trabalhadores, mas tinha como um dos objetivos fomentar a indústria no país, já que, com o congelamento dos preços dos alugueis, o investimento no setor da construção deixava de ser interessante. Nesses termos, o Estado buscou canalizar os recursos do setor construtivo para o setor de indústrias, o que estimulou o modelo de desenvolvimento 
econômico que queria impulsionar (BONDUKI, 1994). No entanto, a impulsão da industrialização no país não pode ser entendida sem a própria participação direta do Estado nesse processo, já que as grandes empresas estatais promoveram as condições para que o capital estrangeiro, sobretudo as indústrias automobilísticas, sentassem as bases no território nacional (SIMONI SANTOS, 2015).

Como resultado da Lei do Inquilinato, os proprietários começaram a usar de diversos artifícios para expulsar os inquilinos e aumentar os lucros com suas casas de aluguel, como a danificação e o destelhamento das casas, a cobrança de taxas adicionais e a venda do imóvel. Assim, em um contexto em que o prefeito Prestes Maia implantava o Plano de Avenidas com o objetivo de "revitalizar" as áreas centrais, ocorre uma forte onda de despejos dos trabalhadores, atingindo de 10 a 14\% dos paulistanos e expulsando a população mais pobre das áreas urbanas com infraestrutura básica para as áreas mais afastadas da cidade sem nenhum tipo de suporte urbanístico (BONDUKI, 1994).

As resistências contra as leis de despejos aconteceram tanto de maneira mais geral como mais pontual, onde grupos de inquilinos do mesmo cortiço ou prédio de apartamento se organizavam para escapar do despejo. Algumas revoltas foram marcantes, como, por exemplo, o movimento contra o despejo de 110 famílias do Edifício Carmine Sérgio, quando os moradores realizaram passeatas e concentrações em gabinetes governamentais (BONDUKI, 1994).

Nesse momento, os inquilinos se dirigiam ao Estado em suas reivindicações e não mais ao proprietário, o que refletia a nova posição do Estado em relação à habitação. Segundo Bonduki (1994), essa posição de apontar a responsabilidade do Estado com a moradia é reforçada pelo Partido Comunista do Brasil - PCB, que dirigia boa parte dos movimentos populares na época, e pelos Comitês Democráticos e Populares.

Os baixos salários nas indústrias e os preços cada vez mais altos dos alugueis impunham aos trabalhadores a necessidade de encontrar novas soluções de moradia, situação que se acentua com o pós-guerra. Onde os trabalhadores despejados morariam? E os novos habitantes que chegavam em São Paulo buscando trabalho, como os nordestinos?

A partir desse momento, a cidade de São Paulo começa a crescer em direção as periferias e os trabalhadores começam a autoconstruir suas próprias casas. Essa forma de expansão da cidade, ao mesmo tempo em que representa uma forma de sobrevivência 
para a classe trabalhadora, que não podia continuar nas áreas centrais, torna-se um negócio para os loteadores e empresários de ônibus. Os bondes eram os principais transportes até o final da década de 1940 e apresentavam limitações de circulação devido à necessidade prévia de infraestrutura. Com a mudança do sistema de transporte, que passou a ser baseado no ônibus, os loteamentos esparsos poderiam ser atendidos com mais facilidade. Assim, empresas particulares de ônibus tiveram grande aumento nos lucros. Os loteadores também aproveitaram para vender lotes rurais para cumprirem funções urbanas, bem como para especular em cima de terrenos vazios que mais tarde seriam vendidos com preços mais altos (KOWARICK, BONDUKI; 1994).

Não se tratava de ausência de planejamento urbano, já que a prefeitura tinha total ciência da abertura desses loteamentos e sabia que o poder público não iria acompanhar essas frentes de expansão da cidade com os serviços de urbanização necessários. Assim, melhor do que pensar que a cidade se perdia de vista, é compreender que o poder público fazia vistas grossas para essa forma precária de expansão da cidade. Ademar de Barros, em 1947, chega a dizer aos trabalhadores que "podem construir suas casas sem planta que a prefeitura fecha os olhos" (KOWARICK, BONDUKI, 1994). De acordo com o Ariovaldo de Oliveira (1978), a própria ideia de "caos urbano" é um modo de pensar capitalista, porque os "advogados do caos" propõem o investimento maciço de capitais para resolvê-lo, estimulando inclusive a especulação imobiliária.

Nesse sentido, a crise de moradia que expulsou a população trabalhadora das áreas mais valorizadas, assim como o salto do processo de industrialização e o consequente fluxo migratório para São Paulo, bem como os baixos salários que eram pagos, explicam, em grande medida, a busca pelas periferias como solução para sobrevivência na metrópole. Nos loteamentos distantes do centro, onde ainda havia preços compatíveis com os salários dos trabalhadores, essa parcela da população conseguia suas casas autoconstruindo. Segundo Rodrigues e Seabra, a especulação do mercado de terras gera uma espécie de reprodução ampliada da periferização:

O aumento do significado da solução da moradia dos trabalhadores, através da construção da casa própria pela via da autoconstrução nos loteamentos da periferia da cidade, vincula-se ao padrão de crescimento das cidades no processo de desenvolvimento do capitalismo no Brasil. Este leva à constituição de um volumoso (e especulativo no dizer frequente de autores e administradores que lidam com o assunto) mercado de terras, mercado firme em razão do desenvolvimento econômico da cidade, que redefine constantemente o preço dos terrenos, o que contribui para criar uma pressão crescente através da 
elevação dos alugueis, das taxas e dos impostos públicos, etc. sobre as populações de baixos salários tendendo a expulsá-las numa espécie de reprodução ampliada da periferização, já que a cidade veio aumentando significativamente seu efetivo demográfico e de populações de rendimentos baixos em particular (RODRIGUES, SEABRA, 1986, p. 45 e 46).

A partir desse momento, a ideia de metrópole se fortalece, generalizando-se na década de 1950 com o desenvolvimento industrial. A metrópole aparecia como lugar central da modernidade e o parâmetro eram as experiências analisadas por cientistas sociais alemães de grandes cidades como Berlim ou Viena (DAMIANI, 2000). No entanto, a desigualdade social nas cidades, que antes se apresentava na correlação de forças entre as várzeas e as colinas, e que agora era identificada na relação centro/periferia, vai adquirindo dimensões que atestavam contra esse status de modernidade generalizada. Surge a metrópole do capital industrial, dos negócios e da urbanização como negócio; e a metrópole das grandes periferias, de milhões de habitantes formando um anel periférico, onde estão casas autoconstruídas e favelas, a comercialização clandestina de loteamentos, mutirões etc. (DAMIANI, 2004; ROLNIK,1994). Segundo Kowarick e Bonduki (1994, p. 154):

O progresso e o moderno terminavam nas longas e intermináveis filas de ônibus das praças Clóvis ou do Correio, na zona central da cidade, iluminadas pelo neón da Coca-Cola, do Açúcar União e do Jeep Willis. A partir daí, era a espera, o ônibus lotado, o barro, a luz de vela e a água do poço contaminada.

Assim, nesses espaços da periferia que se formavam naquela conjuntura, o transporte era o único serviço que estava minimamente acessível, apesar do imenso transtorno do trabalhador para usá-lo, pois sem o ônibus era inviável a ocupação dos espaços distantes da cidade. Os demais serviços, como saneamento básico, iluminação, atendimento médico, asfaltamento e creches estavam totalmente aquém do necessário e foram sendo conquistados pelos movimentos populares nos bairros pouco a pouco.

Segundo Kowarick e Bonduki (1994), a luta nas periferias pode ter começado quando o Partido Comunista Brasileiro -PCB mapeou os loteamentos periféricos como locais de formação de base política de apoio. Em sua fase legal (1945-47), o Partido foi importante para a formação de dezenas de Comitês Democráticos e Populares na periferia, onde os problemas dos bairros eram identificados e encaminhados ao poder público. Quando o PCB e os Comitês foram repreendidos em 1947, os movimentos e os moradores 
organizados da periferia não recuaram e surgiram outras formas de mobilização, como as Sociedades Amigos de Bairro - SAB (op. cit.).

Esses movimentos populares da periferia estavam permeados por uma lógica populista. Um exemplo foi Jânio Quadros que se aproximou de lideranças de bairros e SABs e ganhou a prefeitura de São Paulo em 1953. Com a transformação de muitos comitês Jânio-Porfírio em SABs, Jânio foi eleito em 1954 para governador e, depois de seis anos, para presidente da República. No entanto, a classe trabalhadora não foi mera expectadora nesse período e com a instabilidade gerada com a renúncia de Jânio, as forças sociais começaram a se organizar em torno de outras reivindicações (KOWARICK, BONDUKI, 1994; SINGER, 1982).

\section{2. $\quad O$ início de um debate sobre reforma urbana}

Em meio a todos esses conflitos ocorrendo nas periferias das grandes metrópoles e em resposta a esses problemas, surgem as primeiras discussões no Brasil sobre uma reforma urbana. O sentido do conceito é amplo, relacionado

[...] às tentativas de regulamentar normas e intervenções urbanas visando garantir o direito à cidade e à habitação, na perspectiva de fazer valer a função social da propriedade e de limitar o direito absoluto de propriedade (BONDUKI, 2018, p. 9).

O debate surge no contexto das reformas de base formuladas durante o governo de João Goulart ${ }^{11}$, que governou o país de 1961 a 1964, ano em que um golpe militar daria início ao longo período comandado por militares no país. A discussão sobre uma reforma urbana se estende até os dias de hoje com conteúdos diferentes, embora haja algumas aproximações entre as pautas do presente e do passado (BONDUKI, 2018).

Como já foi explicado anteriormente, o marco da reforma urbana no Brasil se deu com a realização do Seminário de Habitação e Reforma Urbana - SHRU, realizado em 1963, em duas fases, a primeira em Petrópolis - RJ e a segunda na cidade de São Paulo, e foi promovido pelo Instituto de Arquitetos do Brasil (IAB) e pelo Instituto de Previdência e Aposentadoria dos Servidores do Estado (Ipase) (BONDUKI, 2018).

\footnotetext{
${ }^{11}$ As reformas de base inicialmente se referiam às reformas administrativa, bancária, fiscal e agrária e, num segundo momento, são integradas as reformas urbana, educacional e eleitoral (FERNANDES, 2019 apud FRIDMAN, 2014).
} 
O espaço urbano também era uma preocupação crescente da Geografia e dos geógrafos naquele momento. Porém, não houve a presença de geógrafos no SHRU, o que se deve em grande parte por ter sido um evento fechado principalmente entre os arquitetos. No entanto, é importante pontuar que, naquele momento, muitos geógrafos das academias e da AGB estavam ainda instrumentalizados com uma geografia tradicional, que não garantia a compreensão dos conflitos e contradições que estavam sendo produzidos no espaço urbano, como as questões relativas à especulação imobiliária, a falta de moradia e todas as lutas que tinham sido organizadas até então e que se deslocavam cada vez mais para as periferias. Haviam também os geógrafos voltados ao planejamento urbano, sobretudo nos trabalhos desenvolvidos pelo IBGE e que utilizavam as contribuições da geografia urbana do francês Michel Rochefort. Mas estes também não estavam envolvidos com a discussão sobre a reforma urbana.

Por outro lado, apesar de seu marco no Brasil ter sido o SHRU, entendemos que o tema da reforma urbana e suas origens devem ser estudados pensando na escala latinoamericana e admitindo múltiplos sujeitos, de diferentes áreas e profissões.

De acordo com Ana Fernandes (2019), a expressão "reforma urbana" apareceu antes em Cuba, quando ocorreu a aprovação da "Ley da Reforma Urbana" em 1960. A aprovação dessa lei, junto com a "Ley de los Solares y Fincas de Recreo"12, foi considerada o último passo do programa reformista em Cuba, marcando a passagem para um novo programa de luta da Revolução. Essa nomeação coloca a cidade como protagonista:

Ao nomear a reforma como urbana, inaugura-se uma nova modalidade de designação do processo reformista, na qual a cidade tem um papel protagonista, sem abandonar, no entanto, seus vínculos com o campo. Assim, a reforma urbana passa a congregar diversas das problemáticas anteriores - nomeadas, por exemplo, como reforma social, reforma fundiária, reforma da habitação, mesmo que fortemente tensionada por esta última (FERNANDES, 2019, p. 77).

Esse protagonismo do urbano e a expansão do uso da expressão "reforma urbana" para outras cidades da América Latina se deu com intensidades e temporalidades distintas, de acordo com suas particularidades históricas, sendo que o Brasil provavelmente foi o primeiro a adotar o nome após os cubanos (FERNANDES, 2019). Nesse sentido, a

\footnotetext{
${ }^{12}$ Assim como a Ley de Reforma Urbana, a Ley de los Solares e Fincas de Recreo se direcionava a combater o uso especulativo do solo urbano (FERNANDES, 2019).
} 
discussão sobre as origens da reforma urbana deve ser feita de uma maneira mais ampla, extrapolando os debates que aconteceram no Brasil.

Apesar do período ser de receio do avanço do comunismo na América Latina dentro do contexto da Guerra Fria e da Revolução Cubana, o que fez com que as propostas mais radicais fossem afastadas e que até a expressão "reforma urbana" fosse banida inicialmente, uma parte significativa das propostas discutidas no SHRU foi considerada adequada aos moldes conservadores do governo militar (BONDUKI, 2018) ${ }^{13}$.

A criação do Banco Nacional de Habitação -BNH, por exemplo, vai ao encontro da recomendação tirada do SHRU de criação de um órgão central que fosse encarregado da questão urbana e habitacional. Segundo BONDUKI (2018, p. 33):

É desse período a famosa frase "a casa própria faz do trabalhador um conservador que defende o direito de propriedade", atribuída a Sandra Cavalcanti, primeira presidente do $\mathrm{BNH}$, expressando a preocupação de fazer da política habitacional um instrumento de combate às ideias comunistas e progressistas, em tempos de Guerra Fria e de intensa polarização política e ideológica em todo o continente latinoamericano.

Outra indicação do Seminário era a criação de órgãos de administração para solucionar os problemas em comum dos municípios conurbados, proposta que também foi retomada em 1973, quando as noves regiões metropolitanas foram criadas (BONDUKI, 2018), conforme ainda vamos analisar.

No entanto, de acordo com Rodrigues (1993), o planejamento urbano e o urbanismo do regime militar amorteceram a proposta da reforma urbana. Esse amortecimento ocorreu pela repressão aos movimentos populares, mesmo nas reinvindicações mais simples, como o direito à saneamento, saúde e educação, que contraditoriamente são itens essenciais ao próprio desenvolvimento.

\subsection{O papel do IBGE em uma Geografia Urbana Aplicada}

Já existiam no Brasil desde o século XIX Institutos Histórico-Geográficos e Sociedades de Geografia, cujos membros, em sua maioria, tinham outras formações (assim como no ensino secundário). Eram diplomatas, militares, altos funcionários, engenheiros, advogados, jornalistas. No entanto, o Estado necessitava de entidades mais

\footnotetext{
${ }^{13}$ Algumas ações na área da habitação do governo militar retomaram propostas formuladas no SHRU e que também já tinham sido estudadas no período Vargas (BONDUKI, 2018).
} 
qualificadas para lidar com as atividades estatísticas, geográficas e cartográficas do governo (GEIGER, 1988).

O IBGE era peça chave para cobrir essa lacuna. Para a sua criação em 1938, houve a junção de agências federais que já existiam: o Instituto Nacional de Estatística e o Conselho Brasileiro de Geografia. Em 1937, foi criado o Conselho Nacional de Geografia - CNG, que junto ao já existente Conselho Nacional de Estatística, passaram a compor os órgãos colegiais do IBGE (ALMEIDA, 2000; GEIGER, 1988).

A ampliação da Geografia acadêmica que ocorria naquele momento dava as condições para a criação de um órgão oficial de Geografia, bem como a introdução de uma geografia moderna no país, que além de reforçar o ensino como um instrumento ideológico de aprofundamento de uma consciência nacional, também embasaria pesquisas importantes para a administração e o controle do território que passava por um processo de integração econômica e espacial (GEIGER, 1988).

Em relação ao Conselho Nacional de Geografia, Geiger (1998, p. 62) identifica uma de suas finalidades, que era a de aderir a União Geográfica Internacional:

Depois de ter contribuído para a expansão política e econômica de cada país, o campo geográfico dos países do centro promoveu novas formas de organização e criou a União Geográfica Internacional - UGI. Um sinal da marcha do mundo para novas fases prenunciadoras da globalização. A criação do Conselho Nacional de Geografia - CNG, em 1937, representou justamente, de um lado, a atuação da UGI no jogo hegemônico através da difusão de ideias, cultura, técnicas: anos antes, De Martonne, presidente da UGI, visitava o Brasil, e solicitara a nossa adesão à mesma. Formalmente, a fundação do CNG foi para servir de instrumento a esta adesão.

Além dos interesses hegemônicos dos países "do centro", havia, portanto, um forte interesse do Estado em criar as bases para o IBGE. Para o Estado brasileiro, tratava-se da construção de novas técnicas e de novos conhecimentos a serviço da centralização do poder, num país que até então era agrário e fragmentado. Para conseguir a integração espacial e a modernização do país, era preciso "um discurso descritivo, a mensuração, o controle do território e, também, dividir para reinar, ou seja, a divisão regional" (GEIGER, 1988, p. 62).

Nos primeiros números da Revista Brasileira de Geografia, revista de autoria do IBGE desde 1939, foram publicados artigos que ditavam a lógica da época: de Pierre Deftontaines (1939), “descrevendo a dimensão continental do Brasil e dando o tom da nova Geografia acadêmica que estava sendo introduzida, a linha vidalina, onde a moldura 
do quadro natural comanda a organização das atividades humanas"; e de Moacyr F. Silva (1939), "focalizando a Geografia dos transportes, o instrumento da integração" (GEIGER, 1988, p. 63).

De acordo com Almeida (2000), era muito importante conhecer os aspectos físicos da superfície e do subsolo, os padrões espaciais da ocupação humana e econômica e cartografar o espaço como base para a criação das empresas estatais que garantiriam nas décadas seguintes a ampliação do processo de industrialização/urbanização, principalmente na Região Sudeste, como a Companhia Vale do Rio Doce (1942), a Fábrica Nacional de Motores (1943), a Companhia Nacional de Álcalis (1943), a Companhia Siderúrgica Nacional (1946) e a Petrobrás (1953).

Almeida (2010) é autor de uma tese bastante completa sobre os principais geógrafos que trabalharam no IBGE no período de 1938 a 1998. Ao longo de seu trabalho, mapeia também as principais influências teórico-metodológicas de cada período da instituição. Afirma que Pierre Deffontaines, além de toda a sua importância para os cursos de Geografia na USP e na UDF, bem como seu papel na criação da AGB, também é uma das principais influências para o trabalho dos geógrafos no IBGE na década de 1930, sendo responsável inclusive pela supervisão da montagem da Revista Brasileira de Geografia em 1939. Francis Ruellan também teve uma grande influência para os que entraram nas décadas de 40 e 50 e Michel Rochefort para os que ingressaram nos anos 60, sobretudo na área de planejamento. Afirma também que Leo Waibel e Preston James, diferentemente de Ruellan ou Rochefort, trabalharam com grupos pequenos na área de colonização, mas deixando, no entanto, "boas obras e bons discípulos", como Orlando Valverde, Walter Egler e Speridião Faissol. Assim como Pierre Dansereau, biogeógrafo canadense que deixou trabalhos e garantiu cursos no Canadá para alguns ibegeanos, como Alceu Magnanini, Dora Amarante Romariz e Edgar Kuhlmman.

A atuação do geógrafo nas tarefas de planejamento foi bastante intensa no interior do Instituto Brasileiro de Geografia e Estatística. É uma prática inerente aos próprios objetivos de criação do Instituto e do papel que os geógrafos tinham naquele projeto do Estado.

De acordo com Faissol (1988, p. 93), “no Brasil o fato de existir um Instituto Brasileiro de Geografia e Estatística, com um Departamento de Geografia próprio, tem tido enorme importância no papel que a Geografia tem desempenhado no processo de planejamento". Para Almeida (2000), o sistema de planejamento no Brasil nasceu junto 
com a Geografia da academia, sendo organizadas tecnicamente no Rio de Janeiro, pela mesma figura de Pierre Deffontaines. A professora Nice Lecoq Muller (1961, p. 55) colocou também a importância das Assembleias Anuais da AGB, que aconteceram de 1945 até 1970, para que a Geografia tenha sido considerada uma "ciência aplicada, que tem sua palavra a dar nos planejamentos regionais e numa série de trabalhos de ordem administrativa". Da mesma forma, Bonfim (2007) lembra que os Encontros Nacionais de Geografia, como o de Prudente em 1972, contando com a presença de diversos órgãos oficiais, voltavam-se para as ações em planejamento.

Nesse sentido, verifica-se que apesar do destaque do IBGE em realizar as tarefas de planejamento regional e territorial, que cada vez mais eram voltadas para uma realidade urbana, as reflexões dos geógrafos sobre esses "problemas" não ficavam somente nesse espaço, ocorrendo também nos encontros da AGB e nas universidades.

Milton Santos (1959, p. 102) no final da década de 1950 14 já avaliava que “em vários países a Geografia vinha "tomando essa direção e os geógrafos são cada vez mais chamados a ajudar nos programas de planejamento". O geógrafo baiano enumera experiências em vários países tanto socialistas como capitalistas, durante a Guerra Fria. Em relação ao Brasil, elucida a importância do Conselho Nacional de Geografia como um "órgão de Geografia aplicada" e retoma a fala do Diretor de Geografia do CNG da época, Antônio Teixeira Guerra, para um jornal, de que o "geógrafo é a figura central de todo planejamento regional".

A importância dos geógrafos nos assuntos de planejamento se deu com o significado atribuído ao próprio espaço, ou melhor dizendo, ao território nacional, a partir do governo Vargas, especialmente no Estado Novo, quando o país precisava ser amplamente conhecido, integrado e dividido cartograficamente de acordo com os interesses políticos e econômicos da época.

\subsubsection{Menos estados e mais regiões}

De acordo com Geiger (1988) e Faissol (1988), o tema regional surgiu como uma lógica que se superpunha à lógica da Federação, que era vista como nociva à estabilidade

\footnotetext{
${ }^{14}$ Pedro Geiger (1988) afirma que até a segunda metade dos anos 50, o termo "planejamento", referindose à intervenção estatal, era banido nos meios oficiais, por ser considerado subversivo.
} 
política do país, sendo necessário reduzir o poder dos estados. Após essas primeiras ações de regionalização, estas passaram a ocupar lugar permanente nas atividades do IBGE:

Em regime autoritário, o governo central tende a assumir a representação das diversas escalas geográficas. Como se sabe, instalada a República, as antigas províncias do Império se tornaram estados, governados por presidentes eleitos. O Estado Novo, em 1937, derruba a autonomia estadual, nomeou interventores governadores, queimou em cerimônia pública, no estádio São Januário, as bandeiras estaduais, ao gosto da época. Além disto, o governo iria intervir posteriormente no recorte das unidades regionais político-administrativas, medida que vinha sendo defendida por Teixeira de Freitas, que propunha a redução da dimensão política e espacial dos estados. Em 1943, alguns estados foram desmembrados, dando origem a novos Territórios Federais, além do Acre, já existente. Alguns, como Iguaçu e Ponta Porã, foram depois reabsorvidos por Mato Grosso e Paraná. Outra expressão de o Estado assumir maior representação espacial foi a institucionalização das divisões regionais. Entre outros significados, representava a superposição, as unidades históricas de estados e municípios, de novos recortes do território, praticados pelo poder central, para atender as suas racionalizações. Terminada a fase autoritária do Estado Novo, o tema regional ocuparia lugar permanente nas atividades geográficas do IBGE, ligadas à questão do desenvolvimento regional (GEIGER, 1988, p. 63).

A primeira divisão regional do Brasil foi coordenada pelo geógrafo Fábio Macedo Soares Guimarães. Essa divisão tinha como finalidade a produção de dados estatísticos e, já naquele momento, pensava-se em obter dados para o planejamento (FAISSOL, 1988). A primeira divisão regional brasileira foi "o embrião de uma ideia de planejamento espacial para o governo federal" (ALMEIDA, 2000, p. 46).

Guimarães (1941) publica a proposta de sua divisão em um artigo da Revista Brasileira de Geografia, onde aparecem as suas influências da escola francesa, como Vidal de La Blache, Camille Vallaux, Jean Brunhes, Lucien Febvre, Lucien Gallois e Pierre Deffontaines, sendo este último seu professor na primeira turma da Universidade do Distrito Federal e colega no primeiro núcleo do futuro Conselho Brasileiro de Geografia, entre 1935 a 1938 (ALMEIDA, 2000).

O resultado desse trabalho realizado por Macedo foi a aprovação pelo governo federal, em 1941, de uma regionalização que dividia o Brasil em cinco regiões: norte, nordeste, leste, sul e centro-oeste. A base dessa regionalização, apesar de algumas modificações, ficou valendo como oficial até o final dos anos 1960 (CONTEL, 2014). 


\subsubsection{Geografia e Brasília}

Em 1940, chegou ao Brasil o francês Francis Ruelan, sendo ele o responsável pela formação da segunda geração de geógrafos no IBGE e na Universidade do Brasil, além de sua atuação na $\mathrm{AGB}^{15}$. Nesse mesmo período, surgem também outras linhas de pesquisa, como aconteceu após a chegada do alemão radicado nos Estados Unidos, Leo Waibel, que estudava os processos de colonização (ALMEIDA 2000).

Em pouco tempo começariam os debates para a mudança efetiva da capital do país para o Planalto Central, um debate que já era de longa data e que foi aprovado na Constituição de 1946. Antes da decisão final de construir Brasília na região Centro-Oeste durante o governo de Juscelino Kubitschek, ocorreram muitos embates políticos no Congresso. Para além desse caráter político, que muitas vezes se superpõe à qualquer outro aspecto, muitos estudos técnicos foram feitos e os geógrafos do IBGE tiveram uma forte participação nessas análises para a escolha da localização da nova capital. Esta participação se dividiu em duas partes (FAISSOL, 1988), mostrando mais uma vez que a Universidade o sistema de planejamento do IBGE estiveram ligados (AMEIDA, 2000).

A primeira frente de pesquisa foi orientada pelo professor Francis Ruellan, que coordenou um grupo da Universidade do Brasil, e partiu de uma seleção de oito locais possíveis para a nova capital com o objetivo de fornecer informações sobre estas áreas. Em termos de planejamento, "este grupo estava mais preocupado com as questões do planejamento físico de uma cidade e muito pouco com o problema nacional de localizar uma capital para o país" (FAISSOL, 2000, p. 94).

A segunda frente de estudos foi liderada pelos professores Leo Waibel e Fábio Macedo Soares Guimarães e participavam das discussões um grupo de profissionais do IBGE. Embora a pesquisa também tivesse uma preocupação com os locais, estava voltada para a posição da nova capital no contexto nacional. O grupo considerava importante a conexão com a região Centro-Sul, sem a qual a nova capital poderia perder o contato com a realidade nacional. Assim, optou pelo Triângulo Mineiro, nas proximidades do município de Tupaciguara e de um dos afluentes do rio Paranaíba, numa área de terras férteis que daria apoio de abastecimento à população da futura capital (FAISSOL, 2000). “É preciso não esquecer que o professor Leo Waibel, o orientador científico do grupo, era

\footnotetext{
${ }^{15}$ Segundo Nice Lecoq Muller (1961), Francis Ruellan foi o responsável por introduzir a pesquisa de campo em equipe nas Assembleias Anuais da AGB.
} 
um fiel discípulo de Von Thunnen e procurou inserir a Nova Capital num dos anéis não remotos da cidade e área central de São Paulo" (op. cit., p. 95).

\subsubsection{Redes e planos}

Quatro anos antes de concluída a transferência da capital do Brasil, ocorreu o Congresso Internacional de Geografia (foto 2), evento realizado no Rio de Janeiro que representou um momento de autoconfiança para a Geografia produzida no Brasil, quando geógrafos brasileiros e de outras nacionalidades debatiam lado a lado em terras brasileiras.

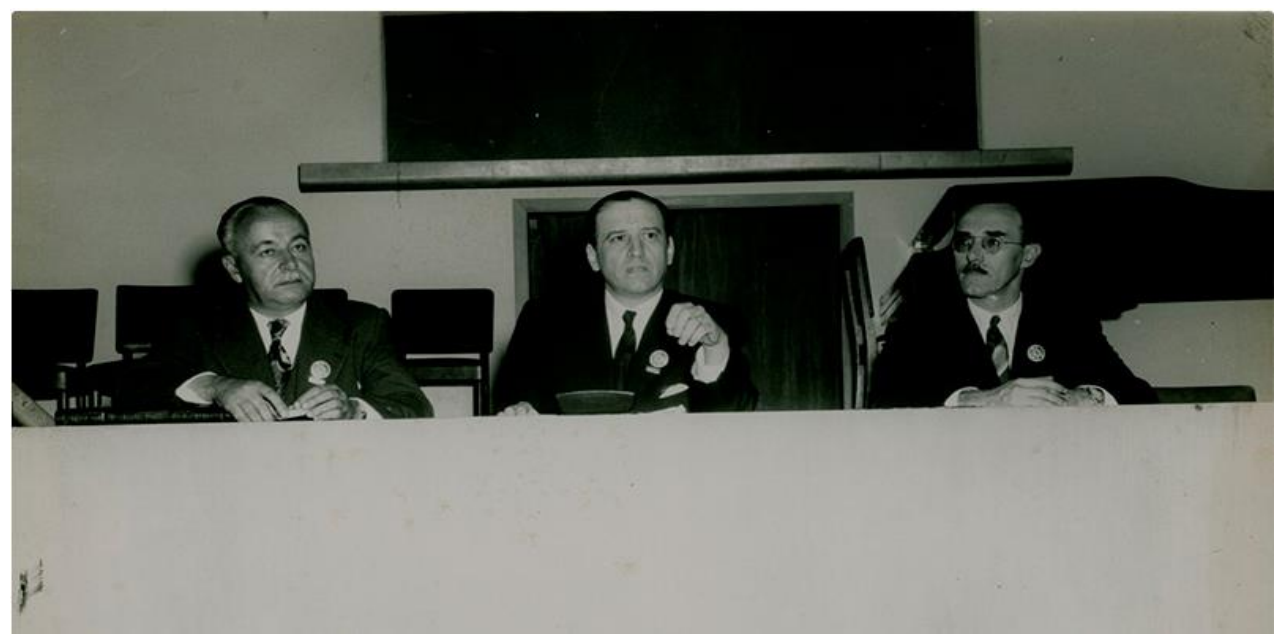

Foto 2: Congresso Internacional de Geografia de 1956. Da esquerda para direita: Francis Ruelan, Christovam Leite de Castro e Fábio de Macedo Soares Guimarães. Fonte: Rede de Memória do IBGE.

Foi a partir desse momento de aproximação que se deu a ida do francês Michel Rochefort (foto 3) ao Rio de Janeiro, geógrafo que estava terminando sua tese de doutorado sobre redes urbanas e foi convidado a dar consultoria ao IBGE e aulas na Universidade do Brasil. Rochefort fez muitos trabalhos em parceria com Nilo Bernardes e Lysia Bernardes no Instituto durante toda a década de 60 (ALMEIDA, 2000).

O principal trabalho orientado por Rochefort foi o realizado pelo Grupo de Trabalho de Geografia Urbana da Divisão de Geografia do CNG, criado em 1961 e coordenado por Lysia Bernardes, denominado "O Rio de Janeiro e Sua Região". O grupo era formado por Lysia e mais nove geógrafas: Maria Rita da Silva de La Roque Guimarães, Maria Francisca Teresa Cavalcanti Cardoso, Maria Emília Teixeira de Castro Botelho, Hilda da Silva, Ceçary Amazonas, Sulamita Hammerly, Olga Maria Buarque de Lima, Elisa Maria Mendes de Almeida e Maria Adelaide Bertucci de Azevedo (ALMEIDA, 2000). 


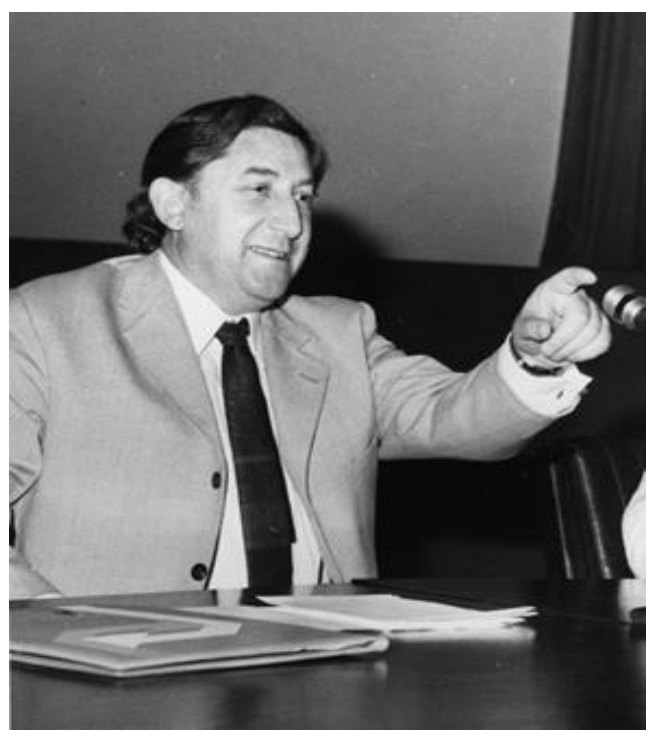

Foto 3: Geógrafo francês Michel Rochefort. Fonte: journals openedition.

Outra obra bastante importante sobre estudos urbanos e sobre redes urbanas, em particular, é o livro "Evolução da Rede Urbana Brasileira" de autoria de Pedro Geiger, publicado em 1963:

...é a primeira obra completa sobre o processo de organização urbana do Brasil, classificando cidades, definindo metrópoles nacionais e delimitando hierarquicamente suas respectivas redes, correlacionando explicitamente as relações entre industrialização e urbanização, que começavam a se delinear no Brasil no final dos anos 50 e início dos 60. (ALMEIDA, 2000, p. 95).

A partir do começo dos anos 1960, muitos estudos começaram a enfatizar aspectos urbanos e industriais no Brasil, refletindo uma urbanização que havia se intensificado no anos 60 e que começava a mostrar seus efeitos em todo o país, mas de forma mais concentrada na região Sudeste. Essa realidade impulsionou pesquisas de geografia urbana, sendo uma parte desses estudos sobre redes urbanas brasileiras, tendo Michel Rochefort como uma grande influência. Esses estudos urbanos foram importantes para as atividades de planejamento do governo federal, principalmente após o golpe de 1964, posição que vai se acentuar com os resultados dos censos demográfico e econômico de 1970 organizados no IBGE (ALMEIDA, 2000).

Com o golpe militar de 1964, o Estado pode cada vez mais realizar políticas de planejamento econômico de "cima para baixo" e criar novas estratégias regionais para o território brasileiro sem nenhuma discussão com a população. Além disso, em nenhum outro período, a ideia de desenvolvimento econômico-social teve um caráter tão territorial como após 1964 (CONTEL, 2014; BOMFIM, 2007), pois a "redefinição da estrutura 
espacial do país era uma condição necessária à manutenção dos altos níveis de crescimento do PIB” (ABREU, 1994, p. 44).

Sem abertura para contestações da sociedade civil num período de autoritarismo, o governo comandou a elaboração de uma série de planos nacionais, como o Programa de Ação Econômica do Governo (1964-66), o Programa Estratégico de Desenvolvimento (1968-70) e o Plano Decenal de Desenvolvimento Econômico (1967-1976) (CONTEL, 2014), que daremos um maior destaque.

Naquele momento, as "regiões naturais" não explicavam mais o território cada vez mais urbanizado. A divisão regional de 1942 tornou-se ultrapassada para a produção das estatísticas territoriais e não oferecia os elementos que eram necessários para a construção dos planos. Neste contexto também o IBGE é transformado numa Fundação e passa a ficar sob a tutela direta do Ministério do Planejamento e da Coordenação Econômica ${ }^{16}$. Como reflexo, o IBGE passou adotou um novo método para dividir o território em regiões, considerando os aspectos econômicos e a urbanização (CONTEL, 2014).

Assim, foram propostas no final da década de 1960 três novas divisões regionais pela instituição, e uma delas divide o Brasil nas cinco grandes regiões que, apesar de algumas mudanças na distribuição dos estados, é uma divisão próxima da que $\operatorname{conhecemos~hoje~}^{17}$ : Região Norte, Região Nordeste, Região Sudeste, Região Sul e Região Centro-Oeste (CONTEL, 2014).

Além da definição das grandes regiões, houve a demarcação das "regiões polarizadas" ou "funcionais" e dos "espaços homogêneos" no território brasileiro, sendo estes definidos a partir da individualização "das áreas que se identificam por certa forma de combinação dos elementos geográficos, sempre dentro de determinado nível de generalização" (IBGE, 1970, t.7, p. 112). Essa tarefa permitiu a criação das "microrregiões homogêneas", sendo definidas 361 para o território brasileiro (CONTEL, 2014) e que poderiam, de acordo Rubens Pereira, Fany Davidovich, Pedro Pinchas Geiger e Roberto Lobato Correia (1967, p. 82), “guiar políticas mais eficientes de estímulos fiscais e investimentos governamentais".

\footnotetext{
${ }^{16}$ De acordo com Bomfim (2007), neste momento o IBGE fica mais exposta às ideologias do regime, cujas demandas se tornarão cada vez mais ligadas às estatísticas e ao fornecimento de dados sobre o território para a elaboração de políticas, o que favoreceu a Geografia Quantitativa. O título da tese do autor vai nessa direção: "Ostentação Estatística (um projeto geopolítico para o território nacional: Estado e planejamento no período pós-64)".

${ }^{17}$ A última mudança importante na regionalização do território brasileiro proposta pelo IBGE se deu entre 1989/1990, após os trabalhos coordenados pelo geógrafo Aluizio Capdeville Duarte (CONTEL, 2014).
} 
O arquiteto e urbanista Nabil Bonduki organizou, recentemente, o livro "A luta pela reforma urbana no Brasil". No capítulo sobre as políticas urbanas durante o regime militar, Maria Cecília Lucchese e Rossela Rossetto retomam a importância do IBGE junto ao EPEA - Escritório de Pesquisa Econômica Aplicada ${ }^{18}$, bem como de Lysia Bernardes para a nova proposta de regionalização que seria feita no final da década de 1960, dando elementos de análise para o Plano Decenal:

Ao ministério [do Planejamento e da Coordenação Econômica] também ficou subordinado o IBGE, que a partir de 1967, por intermédio da geógrafa Lysia Bernardes que lá desenvolveu a metodologia do geógrafo francês Michel Rochefort, elaborou junto com o EPEA a proposta de regionalização brasileira, desenvolvendo diretrizes para o planejamento regional. Essas propostas foram divulgadas no Plano Decenal, que continha também um capítulo dedicado integralmente à política urbana (LUCCHESE; ROSSETTO, 2018, p. 50).

Além da influência de Michel Rochefort ${ }^{19}$ citada pelas autoras, que vem através dos estudos sobre redes urbanas, outras abordagens, também da Geografia, influenciaram este trabalho interdisciplinar que subsidiou o Plano Decenal. De acordo com Contel (2014), devemos considerar também a influência dos economistas François Perroux e Jacques Boudeville, bem como da geografia quantitativa ao retomar a teoria dos lugares centrais de Walther Christaller.

A influência da geografia quantitativa no IBGE será analisada no próximo capítulo, que trata das atividades da AGB e dos geógrafos na década de 1970, momento que o embate da geografia quantitativa e da geografia crítica estava em alta.

\subsection{A cidade e o urbano nos Boletins da AGB}

O Boletim Paulista de Geografia - BPG, periódico da AGB São Paulo, surgiu em 1949 e continua sendo publicado até hoje. Já o Boletim Carioca de Geografia - BCG, da AGB do Rio de Janeiro, teve sua primeira edição em 1948 e a sua última edição foi publicada em 1982. As publicações dos dois boletins, disponíveis online, foram organizados em tabelas com informações sobre cada artigo (título, autor, número/volume e ano). As cores

\footnotetext{
${ }^{18}$ O órgão foi criado por Roberto Campos enquanto Ministro do Planejamento no governo de Castello Branco (1964-1967). Campos foi o responsável pela introdução do ideário da política urbana no governo militar (LUCCHESE, ROSSETTO, 2018).

${ }^{19}$ Para a nova regionalização, o estudo das redes urbanas foi fundamental. As redes traziam a ideia do desenvolvimento econômico no país, porque permitiam entender o funcionamento do território através das "regiões funcionais", mensuradas através dos equipamentos terciários de cada cidade, e também porque a riqueza gerada a partir da década de 1960 e 70 era em grande parte uma riqueza urbano-industrial (CONTEL, 2014; BONFIM, 2007).
} 
utilizadas indicam a influência das diferentes concepções teórico-metodológicas da geografia urbana sobre os textos publicados nos períodos que destacamos em cada capítulo dessa pesquisa.

Do começo da trajetória dos dois boletins até o final da década de 1980, que é recorte temporal final dessa pesquisa, as publicações sobre a cidade e o urbano foram mudando seu caráter teórico-metodológico, refletindo as diferentes escolas de pensamento que influenciaram a Geografia durante o período. Nas décadas de 1940, 1950 e ainda 1960 o método das monografias urbanas de Pierre Monbeig influenciou grande parte dos trabalhos de geografia urbana publicados. Esses trabalhos, embora tenham suas contribuições, estavam descolados da realidade de conflitos e de misérias que foi se dando com o processo de urbanização no Brasil e o crescimento de metrópoles como São Paulo, onde se formavam periferias com casas autoconstruídas e carentes de todo tipo de serviço público.

As Assembleias Anuais realizadas pela AGB ajudaram a elevar as monografias urbanas como estudo-padrão dos geógrafos sobre a cidade nesse período. No entanto, a partir de meados da década de 1950, sobretudo após a realização da Assembleia Anual da AGB de $1957^{20}$, realizada em Colatina - ES, a geografia tradicional começa a demonstrar sinais de mudança, o que se reflete diretamente na geografia urbana com a introdução de novos temas de pesquisa (ABREU, 1994). É nesse sentido que Scarim fala sobre um momento de entrada de novas concepções na ciência:

A assembleia de Colatina deixa perceber sinais de insatisfação e de desejo de uma mudança epistemológica. Logo depois, em Viçosa, acontece um forte debate metodológico. Acentua-se, então, a busca teórica e a manifestação de várias concepções, várias influências e várias tentativas de construção acadêmica (SCARIM, 2008, p. 45).

Antes da Assembleia de Colatina, a geografia urbana estava muito atrelada à construção das monografias urbanas. A partir da iniciativa de Lysia Bernardes, as monografias urbanas tradicionais discutidas nos encontros da AGB passaram a incluir uma análise do grau de centralidade urbana e da determinação da área de influência da cidade (ABREU, 1994). Assim, observamos uma preocupação dos geógrafos que pensavam a geografia urbana em elaborar uma aplicação prática, subsidiando as atividades das instituições de planejamento, como o IBGE.

\footnotetext{
${ }^{20}$ Ano de separação do curso de Geografia do de História na USP.
} 
Nesse sentido, começa uma fase de aprofundamento dos estudos de Geografia na área que Maurício de Abreu (1994, p. 40) chamou de "urbano-regional". Conforme apontamos, são pesquisas baseadas nos estudos das redes urbanas que surgiram a partir da influência de Michel Rochefort e também de Jean Tricart (ABREU, 1994).

Outra temática importante que começa a dar sinais naquele período, reforçando um desejo de mudança epistemológica na geografia urbana, é a formação das metrópoles brasileiras. Na Assembleia de 1959, ocorrida em Viçosa e também citada por Scarim, houve um amplo debate sobre os critérios de definição, os tipos de metrópole etc. (ABREU, 1994).

Abaixo estão os quadros com as publicações em geografia urbana publicadas ao longo do período (1934-1970) no BPG (quadro 1) e no BCG (quadro 2). Destacamos nesse momento os artigos que estavam mais próximos das monografias urbanas e aqueles que se aproximavam mais da área urbano-regional.

Quadro 1 - Publicações sobre cidade e urbano no BPG (1934-1970)

Legenda:

Monografia Urbanas

Geografia Urbano-Regional

\begin{tabular}{|l|l|l|l|}
\hline \multicolumn{1}{|c|}{ Título do artigo } & \multicolumn{1}{|c|}{ Autor (a) } & \multicolumn{1}{c|}{$\mathbf{N}^{\mathbf{0}}$} & \multicolumn{1}{c|}{ Ano } \\
\hline Uma vila do litoral paulista - Icapara & Nice Lecoq Muller & 1 & 1949 \\
\hline Oxford, cidade de ontem e de hoje & Nice Lecoq Muller & 2 & 1949 \\
\hline A “vila" de Itanhaém & José Ribeiro de Araujo Filho & 6 & 1950 \\
\hline A cidade de Olímpia & E. Goulart Pereira de Araujo & 9 & 1951 \\
\hline $\begin{array}{l}\text { As paisagens humanizadas da ilha de } \\
\text { São Sebastião }\end{array}$ & Ary França & & 11 \\
\hline $\begin{array}{l}\text { Aspectos geográficos e problemas da } \\
\text { região de Corumbataí }\end{array}$ & Pasquale Petrone & 11 & 1953 \\
\hline $\begin{array}{l}\text { As indústrias paulistanas e os fatores } \\
\text { da expansão }\end{array}$ & Pasquale Petrone & 16 & 1954 \\
\hline $\begin{array}{l}\text { Aspectos geográficos do crescimento } \\
\text { da cidade de São Paulo }\end{array}$ & Pierre Monbeig & 17 & 1954 \\
\hline $\begin{array}{l}\text { Ensaio de geografia urbana de New } \\
\text { York }\end{array}$ & Pierre Deffontaines & 18 & 1954 \\
\hline $\begin{array}{l}\text { Contribuição à geografia urbana de } \\
\text { Nagoia }\end{array}$ & Kanji Kagami & 14 \\
\hline
\end{tabular}




\begin{tabular}{|c|c|c|c|}
\hline $\begin{array}{l}\text { Porto Alegre, metrópole do Brasil } \\
\text { meridional }\end{array}$ & Jean Roche & 19 & 1955 \\
\hline Crato, "capital" da região do Cariri & Pasquale Petrone & 20 & 1955 \\
\hline $\begin{array}{l}\text { Contribuição ao estudo do norte do } \\
\text { Paraná }\end{array}$ & Nice Lecoq Muller & 22 & 1956 \\
\hline O homem paulista & Pasquale Petrone & 23 & 1956 \\
\hline $\begin{array}{l}\text { Ponta Grossa, capital regional do } \\
\text { oeste do Paraná }\end{array}$ & Elina O. Santos & 24 & 1956 \\
\hline Embriões de Cidades Brasileiras & Aroldo de Azevedo & 25 & 1957 \\
\hline $\begin{array}{l}\text { Rua da Consolação, uma das artérias } \\
\text { da capital paulista }\end{array}$ & José Domingos Tirico & 29 & 1958 \\
\hline $\begin{array}{l}\text { Aix-Em-Provence, uma cidade do } \\
\text { mediterrâneo francês }\end{array}$ & Antônio Rocha Penteado & 30 & 1958 \\
\hline A circulação urbana & Michel Tabuteau & 31 & 1959 \\
\hline $\begin{array}{l}\text { Contribuição ao estudo dos centros de } \\
\text { cidades: o exemplo da cidade de } \\
\text { Salvador }\end{array}$ & Milton Santos & 32 & 1959 \\
\hline $\begin{array}{l}\text { Características e tendências } \\
\text { principais das migrações internas } \\
\text { no Brasil, nas suas relações com a } \\
\text { urbanização e a industrialização }\end{array}$ & José Francisco de Camargo & 33 & 1959 \\
\hline $\begin{array}{l}\text { Brazzaville: alguns aspectos de } \\
\text { uma cidade da Âfrica francesa }\end{array}$ & Pierre Vennetier & 34 & 1960 \\
\hline Sousas, subúrbios de Campinas & José Domingos Tirico & 35 & 1960 \\
\hline $\begin{array}{l}\text { Aspectos dos quadros urbanos da } \\
\text { Baixada Do Ribeira, SP }\end{array}$ & Pasquale Petrone & 38 & 1961 \\
\hline $\begin{array}{l}\text { O sítio urbano de Porto Alegre: } \\
\text { estudo geográfico }\end{array}$ & Aziz Nacib Ab'Saber & 42 & 1965 \\
\hline $\begin{array}{l}\text { Experiências de colonização em } \\
\text { uma área tropical: A Baixada da } \\
\text { Ribeira }\end{array}$ & Pasquale Petrone & 42 & 1965 \\
\hline $\begin{array}{l}\text { Contribuição ao estudo da indústria } \\
\text { têxtil de Americana (Estado De } \\
\text { São Paulo) }\end{array}$ & Helmut Troppmair & 43 & 1966 \\
\hline $\begin{array}{l}\text { Paraná: o quadro geográfico, } \\
\text { histórico e econômico do processo } \\
\text { de urbanização }\end{array}$ & Maria Adélia A. de Souza & 46 & 1971 \\
\hline $\begin{array}{l}\text { Os núcleos de colonização oficial } \\
\text { implantados no planalto paulistano } \\
\text { em fins do século XIX }\end{array}$ & Juerge Richard Langenbuch & 46 & 1971 \\
\hline O bairro industrial do Jaguaré, SP & $\begin{array}{l}\text { Léa Goldenstein, Rosa Ester } \\
\text { Rossini }\end{array}$ & 47 & 1972 \\
\hline $\begin{array}{l}\text { Características do espaço } \\
\text { econômico industrial }\end{array}$ & Armando Corrêa da Silva & 48 & 1973 \\
\hline $\begin{array}{l}\text { Os centros industriais do Estado } \\
\text { São Paulo }\end{array}$ & Beatriz Maria Soares Pontes & 49 & 1974 \\
\hline
\end{tabular}




\begin{tabular}{|c|c|c|c|}
\hline $\begin{array}{l}\text { O processo de industrialização em } \\
\text { São Paulo }\end{array}$ & Armen Mamigonian & 50 & 1976 \\
\hline $\begin{array}{l}\text { Regionalização: tema geográfico e } \\
\text { político - o caso paulista }\end{array}$ & Maria Adélia de Souza & 50 & 1976 \\
\hline $\begin{array}{l}\text { Desenvolvimento econômico e } \\
\text { urbanização em países } \\
\text { subdesenvolvidos: os dois sistemas } \\
\text { de fluxo da economia urbana e suas } \\
\text { implicações espaciais }\end{array}$ & Milton Santos & 53 & 1977 \\
\hline $\begin{array}{l}\text { Desenvolvimento de comunidade } \\
\text { no processo de urbanização: notas } \\
\text { para uma crítica das teorias } \\
\text { sociológicas do planejamento }\end{array}$ & Henrique Rattner & 54 & 1977 \\
\hline $\begin{array}{l}\text { A planificação do desenvolvimento } \\
\text { de regiões atrasadas }\end{array}$ & Henrique Rattner & 56 & 1979 \\
\hline Geografia e Planejamento & Horieste Gomes & 61 & 1984 \\
\hline $\begin{array}{l}\text { Paradigma e movimento social: por } \\
\text { onde andam nossas ideias? }\end{array}$ & $\begin{array}{l}\text { L. A. Machado da Silva, Ana } \\
\text { Clara T. Ribeiro }\end{array}$ & 62 & 1985 \\
\hline $\begin{array}{l}\text { Estado, Divisão Social do Trabalho } \\
\text { e Habitação }\end{array}$ & José Antônio Ronchezel & 64 & 1986 \\
\hline $\begin{array}{l}\text { Habitação e Espaço Social na } \\
\text { Cidade de São Paulo }\end{array}$ & $\begin{array}{l}\text { Arlete Moysés Rodrigues, } \\
\text { Manoel Seabra }\end{array}$ & 64 & 1986 \\
\hline \begin{tabular}{lrrr} 
As condições & de & existência de \\
parcelas & da & \multicolumn{2}{c}{ população } \\
trabalhadora: & a & questão da \\
habitação & & &
\end{tabular} & Regina Célia Bega dos Santos & 64 & 1986 \\
\hline $\begin{array}{l}\text { Cubatão: na busca das favelas e o } \\
\text { encontro do "peão" que permanece }\end{array}$ & Amélia Luisa Damiani & 64 & 1986 \\
\hline $\begin{array}{l}\text { Situação habitacional no Brasil e a } \\
\text { utilização de processos de } \\
\text { autoajuda e ajuda-mútua na } \\
\text { produção de moradias }\end{array}$ & Ros Mari Zenha Kaupatez & 64 & 1986 \\
\hline $\begin{array}{l}\text { Indústria da construção - reflexão } \\
\text { sobre o "atraso tecnológico" }\end{array}$ & Ermínia Maricato & 64 & 1986 \\
\hline $\begin{array}{l}\text { Passado e presente das relações } \\
\text { entre sociedade e espaço e } \\
\text { localização pontual da indústria } \\
\text { moderna no Estado da Bahia }\end{array}$ & Milton Santos & 65 & 1987 \\
\hline $\begin{array}{l}\text { Os shopping-center brasileiros e o } \\
\text { processo de valorização do espaço } \\
\text { urbano }\end{array}$ & Silvana Maria Pintaudi & 65 & 1987 \\
\hline $\begin{array}{lll}\text { Terceirização } & \text { e } & \text { espaço } \\
\text { metropolitano } & & \end{array}$ & $\begin{array}{l}\text { Christian Dennis Monteiro de } \\
\text { Oliveira }\end{array}$ & 65 & 1987 \\
\hline $\begin{array}{l}\text { A intervenção do estado nas } \\
\text { transformações do espaço urbano - } \\
\text { caso Cura em Cuiabá }\end{array}$ & $\begin{array}{l}\text { Cornélio } \text { Silvano } \text { Vilarinho } \\
\text { Neto }\end{array}$ & 65 & 1987 \\
\hline
\end{tabular}




\begin{tabular}{|c|c|c|c|}
\hline $\begin{array}{l}\text { Mudanças nas formas de comércio } \\
\text { varejista e a implantação dos } \\
\text { supermercados na Grande São } \\
\text { Paulo - SP - Brasil }\end{array}$ & Silvana Maria Pintaudi & 66 & 1988 \\
\hline $\begin{array}{l}\text { O processo de terceirização do } \\
\text { espaço metropolitano: um estudo } \\
\text { sobre sua realização na regional } \\
\text { administrativa de Santo Amaro - } \\
\text { São Paulo }\end{array}$ & $\begin{array}{l}\text { Christian Dennys Monteiro de } \\
\text { Oliveira }\end{array}$ & 66 & 1988 \\
\hline $\begin{array}{l}\text { Mapeamento das causas de morte } \\
\text { no município de São Paulo: } \\
\text { Subsídios de uma Geografia } \\
\text { Médica da cidade }\end{array}$ & Helena Ribeiro Sobral & 66 & 1988 \\
\hline $\begin{array}{l}\text { Pensando o processo } \\
\text { valorização e a Geografia }\end{array}$ & $\begin{array}{llll}\text { Odette } & \text { Carvalho de } & \text { Lima } \\
\text { Seabra } & & & \end{array}$ & 66 & 1988 \\
\hline $\begin{array}{l}\text { Migrações, Urbanização e o Setor } \\
\text { Informal: Estudo sobre as Formas } \\
\text { de Comercialização em Área de } \\
\text { Emigração para as Metrópoles de } \\
\text { São Paulo e Rio de Janeiro (Brasil) }\end{array}$ & Nilson Crocia de Barros & 66 & 1988 \\
\hline Paraná que se acaba? & $\begin{array}{l}\text { Denise Rockenbach, Glória da } \\
\text { Anunciação Alves }\end{array}$ & 66 & 1988 \\
\hline $\begin{array}{l}\text { Materiais para o estudo da } \\
\text { urbanização brasileira no período } \\
\text { técnico científico }\end{array}$ & Milton Santos & 67 & 1989 \\
\hline Bixiga: uma ideologia geográfica & Francisco Capuano Scarlato & 67 & 1989 \\
\hline
\end{tabular}

Organizado pela autora. Fonte: AGB-São Paulo.

Nas publicações de geografia urbana do BPG que vão até o final da década de 1960 (quadro 1), os trabalhos pouco extrapolaram as monografias urbanas, as monografias urbanas parciais e os estudos regionais com capítulos monográficos urbanos (ABREU, 1994), partindo da escala de cidades, bairros e até mesmo ruas. Como exemplos das primeiras, que foram publicadas no BPG no ano de 1955, podemos citar os artigos “Crato, 'capital' da região do Cariri”, de Pasquale Petrone e "Porto Alegre, metrópole do Brasil", de Jean Roche.

Alguns desses trabalhos ofereceram grandes contribuições que são reconhecidas até hoje. Maurício de Abreu destaca o estudo de Milton Santos sobre o centro de Salvador, que dá origem ao artigo "Contribuição ao estudo dos centros de cidades: o exemplo da cidade de Salvador" publicado em 1959 no BPG. Segundo o autor (1994, p. 37), é um dos trabalhos da Geografia Tradicional que "demandaram longos períodos de preparação, 
mas que resultaram em obras que merecem, com justiça, um lugar de destaque na história do pensamento geográfico sobre a cidade no Brasil."

Além disso, destacamos o trabalho "As causas do crescimento recente de Itaboraí - Vendas das Pedras (1970)" de Mauricio de Almeida Abreu e Maria do Socorro Diniz por trazer uma análise sobre a metropolização do Rio de Janeiro, tema que atraiu o interesse de geógrafos após a Assembleia Anual da AGB de Viçosa em 1959 e que passaria a fazer cada vez mais parte da agenda do planejamento no Brasil.

Não existem publicações voltadas para o planejamento (área urbano-regional) nesse período no Boletim Paulista de Geografia, elas só vão aparecer - em alguns momentos em caráter mais teórico do que propriamente uma geografia aplicada - ao longo da década de 1970 e início da década de 1980. Uma das razões para isso é o menor envolvimento dos geógrafos da AGB São Paulo com o IBGE, embora esse contato tenha acontecido nas Assembleias Anuais. Nessa linha, não podemos deixar de citar o artigo publicado em 1976, de Maria Adélia de Souza: "Regionalização: tema geográfico e político - o caso paulista". A geógrafa teve uma grande participação nas ações em planejamento que foram feitas durante o regime militar, como veremos a seguir.

Quadro 2 -Publicações sobre cidade e o urbano no BCG (1934-1970)

Legenda:

Monografias Urbanas

Geografia Urbano-Regional

\begin{tabular}{|l|l|l|l|l|}
\hline Título do artigo & Autor & $\mathbf{N}^{\mathbf{o}}$ & Vol & Ano \\
\hline Função Regional de Formosa & Lucio de Castro Soares & 2 & I & 1948 \\
\hline Região Centro-Ocidental da Bahia & Alfredo J. P. Domingues & 3 & I & 1948 \\
\hline Uma Viagem ao Planalto Central & Speridião Faissol & 5 e 6 & I & 1948 \\
\hline $\begin{array}{l}\text { Duas Vilas no Estado de Santa } \\
\text { Catarina }\end{array}$ & Victor Peluso Jr & 5 e 6 & I & 1948 \\
\hline $\begin{array}{l}\text { Aspectos Geográficos do Bas } \\
\text { Languedoe: Região de Montpellier }\end{array}$ & Elza Coelho de Sousa & 5 e 6 & I & 1948 \\
\hline $\begin{array}{l}\text { Contribuição ao Estudo da Ocupação } \\
\text { Humana do Território do Amapá }\end{array}$ & Lúcio de Castro Soares & 2 e 3 & I & 1948 \\
\hline
\end{tabular}




\begin{tabular}{|c|c|c|c|c|}
\hline $\begin{array}{l}\text { As Veredas e os Gerais na região do } \\
\text { Rio Preto na Bahia (estudo de } \\
\text { geografia humana) }\end{array}$ & Pedro Geiger & 1 & III & 1950 \\
\hline $\begin{array}{l}\text { Notas Sobre a Cidade de Diamantina } \\
\text { e seus Habitantes }\end{array}$ & $\begin{array}{l}\text { Lysia Maria Cavalcante } \\
\text { Bernardes }\end{array}$ & 2 e 3 & III & 1950 \\
\hline A Colonização no Estado de Goiás & Speridião Faissol & 2 e 3 & III & 1950 \\
\hline $\begin{array}{l}\text { A Cidade de Cruzeiro - Notas de } \\
\text { Geografia Urbana }\end{array}$ & Nilo Bernardes & $1 \mathrm{e} 2$ & $\mathrm{~V}$ & 1952 \\
\hline $\begin{array}{l}\text { Notas para o Estudo do Núcleo } \\
\text { Colonial de Santa Cruz (Secção de } \\
\text { Piranema) }\end{array}$ & $\begin{array}{ll}\text { Delnida } & \text { Martinez } \\
\text { Alonso } & \end{array}$ & 1 e 2 & VIII & 1955 \\
\hline $\begin{array}{l}\text { Reconhecimento Geográfico no } \\
\text { Município de Pompéu, M.G. }\end{array}$ & Orlando Valverde & 1 e 2 & VIII & 1955 \\
\hline $\begin{array}{l}\text { Análise preliminar dos tipos de } \\
\text { povoamento no } \\
\text { principalmente sob o ponto de vista } \\
\text { de sua morfologia }\end{array}$ & $\begin{array}{l}\text { José Veríssimo da Costa } \\
\text { Pereira }\end{array}$ & 3 e 4 & VIII & 1955 \\
\hline $\begin{array}{l}\text { Contrastes Regionais da terra norte - } \\
\text { americana }\end{array}$ & $\begin{array}{l}\text { José Veríssimo da Costa } \\
\text { Pereira }\end{array}$ & 3 e 4 & VIII & 1955 \\
\hline $\begin{array}{l}\text { Vargem Grande (alguns aspectos } \\
\text { geográficos) }\end{array}$ & Amélia Alba Nogueira & $1 \mathrm{e} 2$ & IX & 1956 \\
\hline $\begin{array}{l}\text { Origem e evolução urbana de } \\
\text { Garanhuns }\end{array}$ & Hilton Sette & $1 \mathrm{e} 2$ & IX & 1956 \\
\hline $\begin{array}{l}\text { Exemplos de hierarquia de cidades no } \\
\text { Brasil }\end{array}$ & Pedro Pinchas Geiger & 3 e 4 & $\mathrm{X}$ & 1957 \\
\hline $\begin{array}{l}\text { A respeito de "Mapas econômicos das } \\
\text { cidades e regiões do Rio de Janeiro e } \\
\text { São Paulo }\end{array}$ & $\begin{array}{l}\text { Michel Blochu e Pedro } \\
\text { Pinchas Geiger }\end{array}$ & 3 e 4 & $\mathrm{X}$ & 1957 \\
\hline $\begin{array}{l}\text { Santa Teresa, um bairro residencial } \\
\text { no centro do Rio de Janeiro }\end{array}$ & $\begin{array}{lr}\text { Aluízio } & \text { Peixoto } \\
\text { Boynarde e } & \text { Maria } \\
\text { Thereza Soares } & \\
\end{array}$ & 1 e 2 & $\mathrm{XI}$ & 1958 \\
\hline $\begin{array}{l}\text { Alguns problemas sugeridos pelo } \\
\text { estudo da colonização alemã no Rio } \\
\text { Grande do Sul }\end{array}$ & Jean Roche & 1 e 2 & $\mathrm{XI}$ & 1958 \\
\hline A primeira vila portuguesa no Brasil & M. T. de Segadas Soares & $1 \mathrm{e} 2$ & $\mathrm{XI}$ & 1958 \\
\hline $\begin{array}{l}\text { O conceito geográfico de bairro e sua } \\
\text { exemplificação na cidade do Rio de } \\
\text { Janeiro }\end{array}$ & M. T. de Segadas Soares & 3 e 4 & XI & 1958 \\
\hline $\begin{array}{l}\text { Tipos de Localização de Cidades em } \\
\text { Pernambuco }\end{array}$ & Mário Lacerda de Melo & 3 e 4 & $\mathrm{XI}$ & 1958 \\
\hline $\begin{array}{l}\text { Evolução da paisagem urbana do Rio } \\
\text { de Janeiro até o início do século XX }\end{array}$ & $\begin{array}{l}\text { Lysia Maria Cavalcante } \\
\text { Bernardes }\end{array}$ & $1 \mathrm{e} 2$ & XII & 1959 \\
\hline $\begin{array}{l}\text { Notas de viagem à Costa do Marfim: } \\
\text { economia comercial e transformações } \\
\text { da paisagem geográfica na A. O. F. }\end{array}$ & Milton Santos & 1 e 2 & XII & 1959 \\
\hline $\begin{array}{l}\text { Meditação geográfica sobre o Rio de } \\
\text { Janeiro }\end{array}$ & Pierre Deffontaines & 3 e 4 & XII & 1959 \\
\hline
\end{tabular}




\begin{tabular}{|c|c|c|c|c|}
\hline $\begin{array}{l}\text { A organização urbana da Amazônia } \\
\text { Brasileira }\end{array}$ & Michel Rochefort & 3 e 4 & XII & 1959 \\
\hline $\begin{array}{l}\text { Função defensiva do Rio de Janeiro e } \\
\text { seu sítio original }\end{array}$ & $\begin{array}{l}\text { Lysia Maria Cavalcante } \\
\text { Bernardes }\end{array}$ & 1 e 2 & XIII & 1960 \\
\hline $\begin{array}{l}\text { Notas sobre a região de Ponte Nova e } \\
\text { Viçosa }\end{array}$ & Michel Tabutlau & 1 e 2 & XIII & 1960 \\
\hline $\begin{array}{l}\text { A Indústria em Brusque (Santa } \\
\text { Catarina) e suas consequências sobre } \\
\text { a vida urbana }\end{array}$ & Armen Mamigonian & 3 e 4 & XIII & 1960 \\
\hline $\begin{array}{l}\text { O problema da classificação do } \\
\text { habitat }\end{array}$ & Michel Rochefort & 1 e 2 & XIV & 1961 \\
\hline $\begin{array}{l}\text { Uma experiência de colonização na } \\
\text { Baixada Fluminense }\end{array}$ & Roberto Lobato Corrêa & 1 & $\mathrm{XV}$ & 1962 \\
\hline $\begin{array}{l}\text { Aracajú, síntese de Geografia } \\
\text { Humana }\end{array}$ & $\begin{array}{l}\text { José Alexandre Felizola } \\
\text { Diniz } \\
\end{array}$ & 1 & $\mathrm{XV}$ & 1962 \\
\hline $\begin{array}{l}\text { Alguns problemas das grandes } \\
\text { cidades nos países subdesenvolvidos }\end{array}$ & Milton Santos & 1 & $\mathrm{XV}$ & 1962 \\
\hline $\begin{array}{l}\text { Madureira - Tentativa de } \\
\text { determinação da área de influência de } \\
\text { um sub-centro da metrópole carioca }\end{array}$ & $\begin{array}{l}\text { Maria Francisca Tereza } \\
\text { Cavalcanti Cardoso e } \\
\text { Maria Emilia Teixeira } \\
\text { de Castro Botelho }\end{array}$ & 1 & $\begin{array}{l}\text { XVI } \\
\mathrm{I}\end{array}$ & $\begin{array}{l}1965 / 1 \\
966\end{array}$ \\
\hline $\begin{array}{l}\text { As causas do crescimento recente de } \\
\text { Itaboraí - Vendas das Pedras }\end{array}$ & $\begin{array}{l}\text { Mauricio de Almeida } \\
\text { Abreu e Maria do } \\
\text { Socorro Diniz }\end{array}$ & 1 & XXI & 1970 \\
\hline $\begin{array}{l}\text { Relações entre o Desenvolvimento } \\
\text { Econômico Regional e o Sistema } \\
\text { Urbano - O caso do Chile }\end{array}$ & Brian J. L. Berry & 1 & XXI & 1970 \\
\hline Regionalização - análise Quantitativa & Speridião Faissol & 1 & XXI & 1970 \\
\hline $\begin{array}{l}\text { Uma Medida da Função de Direção } \\
\text { das Cidades Brasileiras }\end{array}$ & $\begin{array}{l}\text { Ruth Lopes da Cruz } \\
\text { Magnanini e Olga Maria } \\
\text { Buarque de Lima } \\
\end{array}$ & 1 & $\begin{array}{l}\text { XXI } \\
\mathrm{I}\end{array}$ & 1971 \\
\hline 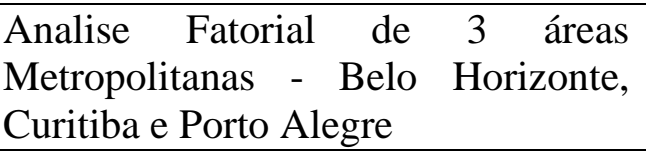 & \begin{tabular}{|l|} 
Elisa Mendes de \\
Almeida e Olga Maria \\
Buarque de Lima \\
\end{tabular} & 1 & $\begin{array}{l}\text { XXI } \\
\mathrm{I}\end{array}$ & 1971 \\
\hline 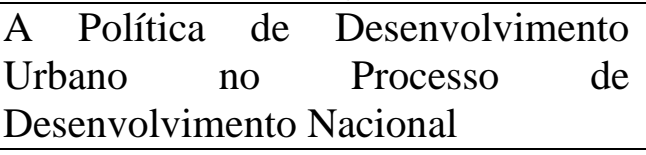 & Zila Mesquita Melo & 1 & $\begin{array}{l}\text { XXI } \\
\text { I }\end{array}$ & 1971 \\
\hline $\begin{array}{l}\text { Contribuição ao Estudo da Estrutura } \\
\text { Interna da Área Metropolitana do Rio } \\
\text { de Janeiro. O caso de Xerém (Duque } \\
\text { de Caxias) }\end{array}$ & \begin{tabular}{|ll|} 
Gilda & \multicolumn{2}{c|}{ Campos } \\
Impellizieri & de $\quad \mathrm{S}$. \\
Martins &
\end{tabular} & 1 & $\begin{array}{l}\text { XXI } \\
\mathrm{I}\end{array}$ & 1971 \\
\hline $\begin{array}{l}\text { A Rede de Localidades Centrais do } \\
\text { Rio Grande do Sul, determinada } \\
\text { através da Teoria dos Grafos }\end{array}$ & Maria do Socorro Diniz & 1 & $\begin{array}{l}\text { XXI } \\
\text { I }\end{array}$ & 1971 \\
\hline $\begin{array}{l}\text { Um Aspecto da Urbanização no } \\
\text { Estado do Espírito Santo }\end{array}$ & Maria do Socorro Diniz & 1 & $\begin{array}{l}\text { XXI } \\
\mathrm{I}\end{array}$ & 1971 \\
\hline $\begin{array}{l}\text { Notas sobre aplicações de Modelo } \\
\text { Probabilístico de Distribuição Poison } \\
\text { ao Sistema Urbano }\end{array}$ & $\begin{array}{|llr|}\text { Pedro Pinchas } & \text { Geiger, } \\
\text { Joao Rua e Luiz } \\
\text { Antonio Ribeiro } \\
\end{array}$ & 1 & $\begin{array}{l}\text { XXI } \\
\text { I }\end{array}$ & 1971 \\
\hline
\end{tabular}




\begin{tabular}{|c|c|c|c|c|}
\hline $\begin{array}{l}\text { Integração de Maricá à área } \\
\text { metropolitana do Rio de Janeiro }\end{array}$ & $\begin{array}{l}\text { Marlene Teixeira } \quad \mathrm{e} \\
\text { William G. Soares }\end{array}$ & 1, & $\begin{array}{l}\text { XXI } \\
\text { V }\end{array}$ & $\begin{array}{l}1973 / 1 \\
974 / 19 \\
75\end{array}$ \\
\hline Fusão Guanabara-Rio de Janeiro & $\begin{array}{l}\text { Antônio José Teixeira } \\
\text { Guerra }\end{array}$ & 1 & $\begin{array}{l}\text { XX } \\
\mathrm{V}\end{array}$ & 1976 \\
\hline $\begin{array}{l}\text { O processo de urbanização no } \\
\text { continente africano }\end{array}$ & $\begin{array}{l}\text { Iná Elias de Castro, } \\
\text { Naria Helena Lacorte e } \\
\text { Nelza Araújo }\end{array}$ & 1 & $\begin{array}{l}\mathrm{XX} \\
\mathrm{V}\end{array}$ & 1976 \\
\hline O Povoamento do Nordeste & Hilda da Silva & 2 & $\begin{array}{l}\text { XX } \\
\text { VI }\end{array}$ & 1976 \\
\hline O Sistema Urbano do Nordeste & Hilda da Silva & 2 & $\begin{array}{l}\text { XX } \\
\text { VI }\end{array}$ & 1976 \\
\hline $\begin{array}{l}\text { Mudanças de população: um estudo } \\
\text { de pequenas cidades nos estados do } \\
\text { Maranhão, Pernambuco e São Paulo } \\
\text { no Brasil }\end{array}$ & Hilda da Silva & 2 & $\begin{array}{l}\text { XX } \\
\text { VI }\end{array}$ & 1976 \\
\hline $\begin{array}{l}\text { A natureza da política habitacional } \\
\text { para grupos de baixa e média renda no } \\
\text { Rio de Janeiro e seus efeitos no } \\
\text { modelo residencial da referida cidade }\end{array}$ & Hilda da Silva & 2 & $\begin{array}{l}\mathrm{XX} \\
\mathrm{VI}\end{array}$ & 1976 \\
\hline Divisão Regional do Brasil & $\begin{array}{l}\text { Fábio Macedo Soares } \\
\text { Guimarães }\end{array}$ & 1 & $\begin{array}{l}\text { XX } \\
\text { VII }\end{array}$ & $\begin{array}{l}1977 / 1 \\
978\end{array}$ \\
\hline $\begin{array}{ll}\text { Desequilíbrios } & \text { regionais- } \\
\text { formulações teóricas } & \\
\end{array}$ & $\begin{array}{l}\text { Maria } \quad \text { Francisca } \\
\text { Thereza C. Cardoso }\end{array}$ & 1 & $\begin{array}{l}\mathrm{XX} \\
\mathrm{VII}\end{array}$ & $\begin{array}{l}1977 / 1 \\
978\end{array}$ \\
\hline $\begin{array}{l}\text { Análise de critérios de população na } \\
\text { identificação de zonas internas na } \\
\text { região metropolitana do Rio de } \\
\text { Janeiro }\end{array}$ & $\begin{array}{l}\text { Haidina da S. B. Duarte } \\
\text { e William Gonçalves } \\
\text { Soares }\end{array}$ & 1 & $\begin{array}{l}\text { XX } \\
\text { VII }\end{array}$ & $\begin{array}{l}1977 / 1 \\
978\end{array}$ \\
\hline $\begin{array}{l}\text { Urbanização e migração na Amazônia } \\
\text { Legal: sugestão para uma abordagem } \\
\text { geopolítica }\end{array}$ & Lia Osório Machado & 1 & $\begin{array}{l}\mathrm{XX} \\
\mathrm{XII}\end{array}$ & 1982 \\
\hline $\begin{array}{l}\text { Organização do espaço e organização } \\
\text { social: o caso de Rondônia }\end{array}$ & Milton Santos & 1, & $\begin{array}{l}\mathrm{XX} \\
\mathrm{XII}\end{array}$ & 1982 \\
\hline $\begin{array}{l}\text { Carajás: processo decisório e impacto } \\
\text { espacial }\end{array}$ & $\begin{array}{l}\text { Maria Célia Nunes } \\
\text { Coelho e Raymundo } \\
\text { Garcia Cota }\end{array}$ & 1 & $\begin{array}{l}\mathrm{XX} \\
\mathrm{XII}\end{array}$ & 1982 \\
\hline
\end{tabular}

Organizado por Larissa Soares de Araujo. Fonte: AGB - Rio de Janeiro.

Os primeiros artigos de geografia urbana do BCG (quadro 2) por mais de uma década também seguiram a linha das monografias urbanas da geografia tradicional. Exemplos são os artigos "A cidade de Cruzeiro", escrito em 1952 por Nilo Bernardes e “Aracaju - Síntese de Geografia Humana”, escrito por José Alexandre Felizola Diniz em 1962.

Algumas publicações dentro dessa época que ficou sobre a égide da geografia tradicional foram consideradas por Maurício de Abreu (1994, p. 41) como verdadeiras 
"investidas exploratórias" por levarem em conta relações, fluxos e processos e que devem ser levadas em consideração por aqueles que se referenciam pelo materialismo histórico até hoje. Alguns desses trabalhos foram publicados no BCG.

Um dos exemplos é o artigo "A Indústria em Brusque (Santa Catarina) e suas consequências sobre a vida urbana", escrito por Armen Mamigonian em 1960. Segundo Abreu, o estudo é o início do que se entende hoje por "agentes modeladores do espaço" e já "chama a atenção para o papel desempenhado pela indústria na produção de um espaço heterogêneo" (1994, p. 41). Outro exemplo é o artigo de Milton Santos "Alguns problemas das grandes cidades nos países subdesenvolvidos" de 1962, que já inovava metodologicamente em trazer a preocupação de definir o que seria a cidade nos países subdesenvolvidos (op. cit.).

As publicações na área "urbano-regional" nesse período aparecem mais bem representadas do que no BPG, o que não é surpresa, levando em consideração que o IBGE e o Rio de Janeiro foram espaços de muita reflexão e ação política a partir dessa abordagem. Como exemplos, citamos "Exemplos de hierarquia de cidades no Brasil, de autoria de Pedro Geiger, e "A respeito de mapas econômicos das cidades e regiões do Rio de Janeiro e São Paulo", de Michel Blochu e Pedro Pinchas Geiger, ambos os trabalhos de 1957; além de "A organização urbana da Amazônia Brasileira", escrito por Michel Rochefort em 1959 e "Divisão Regional do Brasil", de autoria de Fábio Macedo de Guimarães no ano de 1977/1978.

Se levarmos em conta que a geografia quantitativa também teve uma grande influência no planejamento, perceberemos que o número de publicações voltadas para uma geografia aplicada no BCG é ainda maior. No entanto, essa análise será feita no capítulo seguinte. 


\section{CAPÍtUlO 3 - A TRANSFORMAÇÃO DA AGB E OS EMBATES DA}

GEOGRAFIA NA DÉCADA DE 1970

Não é possível analisar a trajetória dos geógrafos e da AGB na década de 1970 e as transformações teóricas-metodológicas da Geografia sem levar em consideração o contexto da ditadura militar. Isso porque, assim como muitos espaços, as universidades públicas eram constantemente vigiadas, desde as salas de aulas até os eventos que aconteciam em seus espaços.

O governo militar contava com um imenso aparato de vigilância. Em 1964 foi criado o Sistema Nacional de Informações (SNI), órgão diretamente ligado à Presidência da República. Também foram instituídas as Divisões de Segurança e Informação (DSIs), nos ministérios civis, e as Assessorias de Segurança e Informação (ASIs), nos órgãos públicos e autarquias. Essa estrutura envolveu, depois de 1967, os já existentes Departamentos de Ordem Pública e Social (DOPs). Nessa primeira fase, a Universidade de São Paulo foi severamente atingida, especialmente a Faculdade de Medicina e os intelectuais e políticos que militavam em oposição ao regime (COMISSÃO DA VERDADE DA UNIVERSIDADE DE SÃO PAULO, v.1, 2014).

Em 1968, a situação ficou ainda mais grave com a promulgação do Ato Institucional 5 - AI5, que suspendia o habeas corpus nos casos de crimes políticos, abrindo margem para muitas prisões arbitrárias. As consequências para a USP foram imensas, ocorrendo a aposentadoria compulsória de muitos professores (COMISSÃO DA VERDADE DA UNIVERSIDADE DE SÃO PAULO, v. 1, 2014). Ainda em relação à USP em todo o período do regime militar:

A abrangência e a intensidade de repressão política cotidiana foram imensas. Um pequeno indicador pode ser apontado quando se observa o número de fichas existentes nos arquivos DEOPs: 1,5 milhão de fichas remissivas. Outro indicador, no caso da USP, é o número de relatórios produzidos - há documentos no acervo do DEOPs que comprovam, a possiblidade de elaborar, em único dia três relatórios. Qualquer manifestação discordante ou mesmo uma festa de confraternização poderia ser objeto de um informe da AESI. Nesse sentido, entendia-se por manifestação discordante, por exemplo, participar de uma festa de confraternização com entrega de convite para mobilização de estudantes (Informe $n^{\circ}$ 014/78/ASI/USP), oferecer um curso de férias sobre o Vietnã, ou ainda, assinar um ofício, solicitando ao reitor providências para que se revertesse a aposentadoria compulsória dos professores Florestan Fernandes, Fernando Henrique Cardoso, Octavio Ianni e Paula Beiguelman, em razão da revogação do Ato Institucional $\mathrm{n}^{\circ} 5$ e do Ato Complementar $\mathrm{n}^{\circ} 75$ (Informe 
n419/ASI/USP/78), gesto levado adiante pelo professor Ruy Coelho, quando exercia o cargo de diretor da FFLCH (COMISSÃO DA VERDADE DA UNIVERSIDADE DE SÃO PAULO, v. 1, 2014, p. 24).

Em relação aos estudantes e ao movimento estudantil, dois fatos foram de grande destaque em 1968: o confronto em São Paulo entre os estudantes do Mackenzie e da Faculdade de Filosofia, Ciências e Letras, quando houve a intervenção do grupo de extrema direita Comando de Caça aos Comunistas (CCC), e a prisão de mais de 900 estudantes após a tentativa de realização do Congresso da União Nacional dos Estudantes (UNE), em Ibiúna-SP (COMISSÃO DA VERDADE DA UNIVERSIDADE DE SÃO PAULO, v.7, p. 4).

Naquele mesmo ano, outro ataque à universidade foi realizado, desta vez contra o Conjunto Residencial da Universidade de São Paulo, o CRUSP. Os militares invadiram os prédios de moradia em busca de materiais "subversivos". Diversos estudantes foram presos, entre eles Ariovaldo Umbelino de Oliveira, hoje professor do Departamento de Geografia da USP. Os prédios ficariam interditados até 1979, quando foram retomados pela iniciativa dos estudantes (VERDI, 2016).

\subsection{Os Encontros Nacionais de Geógrafos}

Os Encontros Nacionais de Geógrafos começaram a ocorrer no início de 1970 após a mudança de estatuto. Esses encontros realizados pela AGB eram - e até hoje são momentos propícios para discussões a partir de diferentes vertentes metodológicas. No entanto, em razão da forte repreensão do período, estes eventos, que representavam aglutinações "perigosas" de estudantes aos olhos dos militares, eram acompanhados de perto por pessoas ligadas ao regime, o que impedia o debate de ocorrer naturalmente. $\mathrm{Na}$ década de 1970, entre outras abordagens que influenciavam os trabalhos científicos dos geógrafos, o embate entre a chamada geografia crítica e a geografia pragmática começava a se dar, mesmo com as limitações impostas pela censura, mas sem também deixar de leva-la em consideração.

Assim, os ENGs que se iniciam na década de 1970 vão acontecer em meio a esse "rebuliço" de teorias e métodos distintos, tendo como pano de fundo um dos momentos mais duros de repreensão ao pensamento e à crítica no Brasil. Muitos geógrafos, naquele momento, liam obras de Karl Marx e outros autores de orientação marxista/progressista e traziam essas reflexões para a Geografia. Por outro lado, a geografia quantitativa, 
abstrata e matemática, estava em alta em alguns departamentos de Geografia, como foi o caso da UNESP de Rio de Claro e da UFRJ do Rio de Janeiro, além do IBGE.

O confronto entres essas duas abordagens - a quantitativa e a crítica, é costumeiramente associado ao ENG de Fortaleza, em 1978. No entanto, apesar da inquestionável importância do ENG de Fortaleza, que se deve também pela indicação de um novo estatuto, mais democrático, as tensões já estavam presentes em Encontros anteriores, aumentando gradativamente do primeiro Encontro em 1972 até $1978^{21}$. Assim, os debates só não foram mais intensos desde o início devido à forte censura sofrida pelas universidades nos anos da ditadura militar.

Durante o primeiro ENG, ocorrido em Presidente Prudente no ano de 1972, o país vivia a época dos grandes projetos realizados pelo governo militar e a Geografia cumpria um papel nesse processo, sobretudo através do IBGE, como foi muito bem explicado por Paulo Bonfim (2007) em sua tese de doutorado. Apesar do destaque do Instituto, o trânsito de geógrafos entre os espaços da AGB, das universidades e do IBGE era bastante forte ${ }^{22}$, o que fazia com que as discussões também ultrapassassem essas barreiras. Dessa maneira, esses debates eram de grande interesse também para o Estado e para o capital, o que explica as dezenas de instituições presentes no $1^{\circ}$ ENG, como IBGE, Incra, Sudene, Sudam, a Diretoria de Hidrografia e Navegação no Ministério da Marinha, o Instituto do Açúcar e do Álcool etc. (BOMFIM, 2007). Esse processo perdurou sobretudo até 1978, quando há um grande questionamento desse sistema.

O professor da UNESP Eliseu Spósito, que esteve presente no Encontro como desenhista e aluno da Faculdade de Filosofia, Ciências e Letras de Presidente Prudente, expos as tensões do debate ainda muito reprimido pelo "medo" entre a Geografia hoje denominada crítica e a geografia quantitativa, falou sobre os principais temas discutidos e a dificuldade em se fazer leituras que poderiam ser condenadas pelo regime político na época:

Era um momento em que tinha poucas pessoas participando. Mesmo assim, lá foram mais ou menos 700 pessoas. E o diretor da AGB local avisava: olha, cuidado que aquela pessoa estranha deve ser olheiro. $\mathrm{E}$ era mesmo. Cada mesa tinha um ou outro. E a pessoa não escondia... Você nunca tinha visto e a pessoa vinha vestida meio como um

\footnotetext{
${ }^{21}$ Após a reforma de 1970, os ENGs passaram a acontecer a cada dois anos, com e exceção dos anos em que coincidem com o Congresso Brasileiro, que ocorre a cada dez anos, como foi o caso do ano de 1974. ${ }_{22}$ Por exemplo, Lysia Bernardes, muito atuante no IBGE, seria eleita presidente na Assembleia Administrativa do $1^{\circ}$ ENG para o biênio 1972-1974 da AGB (BOMFIM, 2007).
} 
"tira" mesmo, não vinha de militar, mas vinha observar. Então havia muito pouco espaço para, vamos dizer, berrar muito. Em 1972, inclusive, se você olhar a História do Brasil, estava em plena efervescência a Guerrilha do Araguaia. Então, as pessoas olhavam tudo que estava acontecendo e, às vezes, convidavam o diretor da faculdade para um depoimento. Nunca aconteceu nada muito sério, porque todo mundo também tinha medo. Mas a grande questão daquele momento, foram os grandes projetos, como a Transamazônica, as grandes barragens que estavam em São Paulo e no Brasil inteiro... Já havia uma divisão entre a Geografia marxista e a Quantitativa, mas a Geografia Quantitativa estava muito forte, e não se podia falar de Marx, não se podia falar de Karl Polanyi, era tudo escondido. Todo mundo que tinha o livro deles, lia escondido. A gente lia, mas não era fácil. Os grandes nomes franceses a gente lia (em francês e em forma de apostila). Mas quem era De Martonne? Era nada de esquerda, eram geógrafos importantes, mas até ler um francês deixava gente preocupado. E como eu era funcionário e aluno, tinha duas frentes me olhando, os professores e os militares. Então só não houve realmente uma grande oposição entre a Geografia marxista e a Quantitativa por causa desse medo (Entrevista a Larissa Araujo, outubro de 2019).

Arlete Moyses Rodrigues, geógrafa a quem retomaremos em outros momentos dessa pesquisa, também escreve sobre esse momento em Presidente Prudente que presenciou:

Um outro momento importante, nas minhas lembranças, foi o Primeiro Encontro de Geógrafos, em 1972, em Presidente Prudente. Reunir mais de 400 profissionais foi um demonstrativo de que a AGB funcionava como um dos motores da produção e da difusão da Geografia. Este episódio, recordo-me bem, deixou a polícia política "impressionada" com o fato de um primeiro Encontro reunir tanta gente no interior do Estado de São Paulo. Além de um demonstrativo da força da comunidade dos agebeanos, neste encontro foi possível assistir a um debate entre posições antagônicas entre a Geografia Quantitativa e/ou Teorética e a Geografia Qualitativa, que ainda não era denominada Crítica (RODRIGUES, 2004, p. 203).

Os dois depoimentos retomam um início - ou uma tentativa - de um embate teórico-metodológico entre as perspectivas presentes no momento. Sobre o Encontro de 1976 realizado em Belo Horizonte - MG, existem relatos detalhados sobre essas tensões que continuavam e ganhavam mais espaço, acompanhando o movimento de luta pela democracia da sociedade. Um dos relatos muito ricos foi este do professor Ariovaldo de Oliveira concedido a Elisa Verdi:

O encontro de Belo Horizonte foi o encontro do embate entre alguns geógrafos marxistas, porque eram poucos, e os empiristas lógicos. Isso tudo foi canalizado na apresentação do Armen [Mamigonian], no último dia. Começou um movimento dentro do encontro dos empiristas lógicos para fazer a crítica ao Armen, e eles elegeram o Roberto Lobato [Correa] para ser o que ia falar. O Lobato tinha acabado de fazer o mestrado nos Estados Unidos, tinha chegado de volta fresquinho com 
as ideias empiristas lógicas bastante fundamentadas. [...] Bem, então foi se criando um clima de oposição. E aí na apresentação, o Armen fez a apresentação dele, maravilhosa. Primeiro geógrafo brasileiro marxista, apesar de não aparecer no doutorado dele. [...] Ele terminou a fala dele e ninguém aplaudiu.

O Lobato pediu a palavra e começou a criticar. Ele usou uma estratégia de fala, discursiva, que era assim: "se você tivesse sido marxista, você teria falado..." e começou a falar lá, a leitura empirista lógica do marxismo. "Se você fosse historicista, você teria feito isso. Se você fosse empirista lógico, você teria feito isso". Em outras palavras: o Armen era um empiricista, não tinha teoria na apresentação dele. Quando o Lobato terminou, depois de falar quase meia hora, o pessoal do IBGE que estava na frente, no salão enorme lá na UFMG, aplaudiu o Lobato até não querer mais. Aí o sangue subiu nas veias, como a gente diz, de forma caipira, e eu pedi a palavra. Fiz uma intervenção dizendo: "olha, senhor Lobato, acho que o senhor não viu que na apresentação do professor Armen tinha isso...", aí fui fazendo um diálogo com o Lobato e ao mesmo tempo mostrando o que de análise marxista tinha na apresentação do Armen. Fiz a minha fala, ficou aquele silêncio sepulcral porque é a intervenção fora do script. Aí em seguida o Manuel Correia [de Andrade] pediu a palavra e também elogiou o Armen. Depois dessas falas, a palavra foi pro Armen, e ele disse: "Lobato, não preciso mais me defender porque o Ariovaldo e o Manuel Correia já me defenderam. Então, eu vou apenas fazer uma resposta curta para você. E como você é carioca, vou usar uns versos do Noel Rosa!", e aí ele canta: "Quem é você, que não sabe o que diz? Meu Deus do Céu, que palpite infeliz" (Ariovaldo de Oliveira em entrevista a Elisa Verdi, 2016, p. 34).

Como é possível perceber, o debate entre as diferentes tendências na Geografia foi muito acalorado e intenso em Minas Gerais. Por isso, concordamos com Verdi (2018), que a renovação crítica na ciência geográfica é muito mais ampla do que o Encontro de 1978, não se tratando de negar a importância desse evento e do seu significado para a AGB e para a Geografia brasileira, mas de entender o processo de renovação como um movimento que não começou neste ano, mas foi se constituindo no correr da década de 1970.

No caso do Brasil, “o processo da ruptura crítica insere-se no momento da ditadura civil-militar, um período de autoritarismo e repressão política, social e intelectual" (Verdi, 2018, p. 35), período em que muitos geógrafos transitavam entre os movimentos de resistência contra a ditadura e os movimentos estudantis, bem como estavam dentro das instituições do Estado pensando o território brasileiro e respondendo também às demandas do governo e do capital. 


\subsection{O Movimento de 78}

Apesar de já ter passado por importantes reformas estatutárias, como aconteceu em 1945 e em 1970, o ponto de maior inflexão da AGB aconteceu com a reforma do estatuto de 1979, pelo seu amplo significado. Essa mudança de estatuto teve um precedente muito forte um ano antes no Encontro Nacional de Geógrafos realizado em Fortaleza. Por isso, essa passagem da entidade ficou conhecida como "Movimento de 78".

São várias as narrativas sobre o Movimento de 78 e a consequente mudança do estatuto da AGB. Entre estas se incluem a dos estudantes do Movimento Estudantil de Geografia da época, como Diamantino Pereira e Douglas Santos, que foram figuras importantes para pressionar a entidade a adotar mudanças, bem como de alguns professores que também foram apoiadores e condutores da reforma, como Carlos Walter Porto Gonçalves, Beatriz Soares Pontes, Roberto Lobato Correa e Ariovaldo de Oliveira (ANTUNES, 2001), este último que tentava ingressar como professor da USP naquele momento.

Entre os sócios efetivos anteriores ao novo estatuto, haviam aqueles que estavam a favor das modificações, como é o caso de Carlos W. Gonçalves e Beatriz S. Pontes, citados anteriormente, e também de Armen Mamigonian (ANTUNES, 2008). Havia, por outro lado, os que estavam contra, não concordando com o teor das mudanças ou com a forma como estava sendo conduzida a alteração da estrutura de participação da AGB. Olhando em retrospecto, existem também aqueles fazem críticas aos rumos que a entidade tomou com este Movimento, seja por ter reafirmado ainda mais a geografia crítica dentro da comunidade geográfica, seja por excluir de uma forma muito radical os geógrafos e as pesquisas que deixaram de estar alinhados diretamente com a AGB.

Um dos exemplos de posição contrária ao Movimento vem do então sócio efetivo José Bueno Conti, hoje professor aposentado da USP. O geógrafo relata que, apesar de hoje entender que a reforma estatutária era necessária, no dia da reformulação do estatuto chegou a se retirar da mesa junto com os também sócios efetivos Araújo Filho, Manuel Correia de Andrade e Gervásio Rodrigues Neto. Quando analisa o papel que a geografia crítica assumiria naquele momento também possui queixas, porque entende que a geografia física e a cartografia perderam muito espaço nas discussões da ciência a partir desse período (José Bueno Conti em entrevista concedida ao BPG, 2008). 
Até então, para se associar à AGB era necessário ser formado e a admissão na entidade só podia acontecer com aprovação em Assembleia, necessitando da indicação de algum membro efetivo ${ }^{23}$. O direito ao voto era restrito a esses membros, embora se admitisse a participação de não formados e não admitidos nas atividades da entidade (PEREIRA, 2008). Em linhas gerais, com a mudança de estatuto os estudantes e professores de Geografia do ensino básico passaram a ter uma efetiva participação na entidade, com direito a fazer parte das decisões. De acordo com Diamantino Pereira (2008), o controle na tomada de decisões contrastava com o trabalho crescente dos associados não efetivos na entidade e com a reivindicação da democracia pelos estudantes para os espaços da universidade e da sociedade como um todo.

Como dito, essa discussão sobre a democratização da AGB eclodiu um ano antes, em Fortaleza, no III Encontro Nacional de Geógrafos:

O III ENG foi rigorosamente um encontro, não apenas no sentido formal dos profissionais de geografia, mas também de experiências que vinham se desenvolvendo em todo o Brasil, em diferentes lugares, por diferentes pessoas, dentro de uma perspectiva crítica. Um encontro que aconteceu num momento em que a sociedade brasileira passava por grandes transformações, com o reaparecimento de importantes agentes sociais, como o Movimento Operário e o Movimento Estudantil [...]. Esse evento que, no fundo, se tornou um clássico divisor de águas, refletiu os processos relacionados às insatisfações e preocupações que já resplandeciam tenuamente sobre os rumos dessa ciência no país (ANTUNES; NETO, 2008, p.)

Mesmo, como dissemos, o marco não dar conta de explicar todo o processo, que foi muito mais longo, o ano de 1978 aparece como uma data de ruptura para a Geografia, sendo muito importante considerar a realidade do momento, ou seja, a conjuntura que envolvia profundas mudanças sociais. Era o período de ascensão dos movimentos operários, da reconstrução do movimento estudantil, de véspera da anistia aos exilados e do surgimento de várias de organizações que depois foram importantes para a fundação do Partido dos Trabalhadores (ANTUNES; NETO, 2008).

Diante dessa efervescência, no ENG de Fortaleza aprovou-se uma Assembleia para a mudança do estatuto da AGB a ser realizada no ano seguinte na USP. Vale lembrar que a UPEGE - União Paulista dos Estudantes de Geografia marcou seu Congresso para os dias que antecederiam este evento em São Paulo, o que garantiu uma grande organização por parte dos estudantes na Assembleia. Com essas mobilizações, aconteceu

\footnotetext{
${ }^{23}$ Existia também a categoria de sócio cooperado.
} 
a aprovação do novo estatuto, que tinha um caráter muito mais democrático que os anteriores por extinguir as categorias de sócios e garantir o pleno direito de participação de todos aqueles que estivessem envolvidos com a entidade.

Diamantino Pereira, que participou desse processo de dentro do movimento estudantil relata qual era a importância de estar dentro da AGB:

Como o movimento estudantil era um movimento onde a luta política era central naquela época, muitas vezes as pautas e as reivindicações ficavam ao nível da luta democrática, contra a ditadura. Você discutia essas questões mais gerais e não se vinculava com as questões específicas dos estudantes. Claro, vou lutar por alojamento, pela residência estudantil lá no CRUSP, pelo preço do bandejão. Tudo isso faz parte da "luta sindical". Mas aquilo que é específico do estudante, ou seja, a qualidade do curso, isso ficava muito de fora da militância política. E foi por isso que nós, estudantes da época, decidimos participar da AGB (Diamantino Pereira, entrevista a Larissa Araujo, maio de 2018).

A busca por "qualidade do curso" de Geografia, citada por Diamantino, também está vinculada ao processo de renovação da ciência, ou seja, ao esforço na produção da(s) geografia(s) crítica(s). Para o Movimento Estudantil de Geografia da época, a sua identidade dependia da renovação e fortalecimento do caráter epistemológico da ciência, sendo que, a simples proclamação da Geografia como um instrumento de uma "práxis" social transformadora, não a tornava automaticamente como tal (ANTUNES; NETO, 2008). Ainda nesse sentido, Douglas Santos coloca:

A militância estudantil deveria ter um papel não só na organização do movimento de rua, das passeatas ou na contraposição do discurso da ditadura militar. Havia uma necessidade de confrontar a partir do próprio conhecimento que nos era próprio, que era a Geografia. Nesse momento, então, a participação dentro da AGB, fez parte para o Movimento Estudantil, da nossa intenção de trabalharmos a ideia de que existiria uma ciência, um conhecimento e que esse conhecimento estava a serviço das classes trabalhadoras (Douglas Santos, entrevista a Larissa Araujo, junho de 2018).

Dessa maneira, a mudança do estatuto abriu as perspectivas da AGB, que agora tinha um novo caminho epistemológico para adotar e poderia participar de forma mais efetiva nos processos que surgiriam no contexto da redemocratização, principalmente voltados para as reivindicações da classe trabalhadora. Abaixo segue o editorial da edição especial do Jornal da AGB (figura 3), escrito pela Comissão Administrativa Provisória formada depois da Assembleia de 1979 e que se responsabilizaria pela AGB até a eleição de uma nova diretoria, já considerando as regras do novo estatuto. Nesse jornal, o estatuto é 
colocado como um primeiro passo de uma série de movimentos que acompanhariam as transformações sociais e políticas do país.

Figura 3 - Jornal da AGB que trata da aprovação do estatuto de 1979

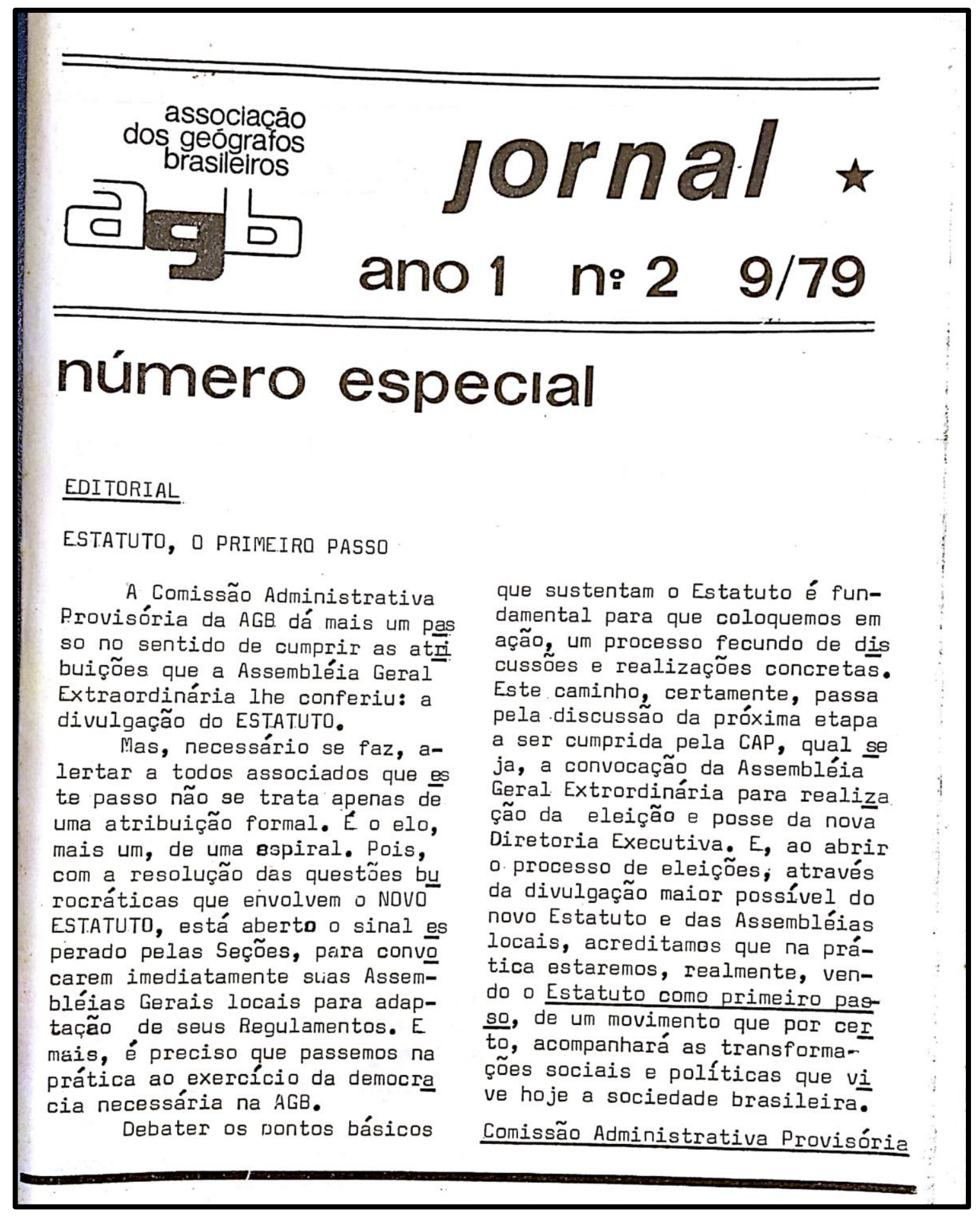

Fonte: Arquivo da AGB Nacional.

Para atingir os próximos passos, muitos agebeanos que referendavam a importância de uma geografia crítica para a analisar a sociedade - onde se destaca nessa pesquisa a realidade do espaço urbano e das múltiplas contradições que se davam nas periferias das 
metrópoles brasileiras -, passariam por vários processos de amadurecimento teórico e de concretização da ação política junto à sociedade, vista como urgente no Movimento de 1978. Por outro lado, outros geógrafos que rechaçavam a geografia crítica, sobretudo por suas visões conservadoras acerca da realidade, passaram a boicotar a AGB e a comporem outras entidades (Ariovaldo de Oliveira em entrevista concedida ao BPG, 2008). Como exemplos, Ariovaldo cita o Encontro Nacional de Geografia Agrária, o Encontro de Geografia Física Aplicada e a Comissão Nacional Geográfica Internacional, esta última formada por geógrafos ibegeanos que saíram da AGB e que conseguiram que fosse retirado o apoio do IBGE à realização do IV ENG que aconteceria na Universidade Federal do Rio de Janeiro em 1980. Esse evento acabou acontecendo na PUC-Rio após os esforços de mediação do geógrafo Orlando Valverde (op. cit.).

\subsection{As cidades: ditadura, desigualdade e movimentos de resistência}

Com a chegada dos transporte público às áreas mais afastadas e a valorização dos lotes centrais de São Paulo, bem como as expulsões dos trabalhadores de suas residências de aluguel e os seus baixos salários, estes vão encontrar nas autoconstruções em espaços periféricos uma nova solução de moradia ${ }^{24}$. A partir de meados da década de 1970, a violência dos processos de valorização do preço da terra em São Paulo e a as dificuldades envolvendo a autoconstrução (uso do tempo livre, trabalho sem remuneração, exaustão física etc.) leva o trabalhador paulistano à outra forma extremamente precária de habitação: as favelas. ${ }^{25}$

Dessa forma, de acordo com Regina Bega Santos (1986), a crise de habitação atinge diferentes setores: o favelado, que só pode pagar um barraco em área de ocupação; o "marginalizado", que sequer consegue integrar o processo produtivo e todos aqueles que, mesmo participando do "mercado imobiliário formal", comprometem parcelas muito altas de seus salários.

\footnotetext{
${ }^{24}$ O valor do salário mínimo reduziu em cerca de $60 \%$ entre 1959 e 1990 e o preço do metro quadrado de terreno nesse período aumentou em 2,5 vezes (KOWARICK, BONDUKI, 1994).

${ }^{25}$ Entre 1973 e 1987, o número de favelados aumentou de 1,1\% da população para 7,7\%, ou seja, houve um aumento de 1031\% (KOWARICK, BONDUKI, 1994).
} 
Nos primeiros anos da década de setenta, muitos consideram que o Brasil estava vivendo um "milagre econômico". No entanto, essa leitura econômica do momento se encaixa muito mais como uma propaganda midiática de governo, na medida em que escamoteia as contradições e a realidade dos diferentes sujeitos que vivenciaram este período, do que como uma leitura comprometida com a interpretação da realidade. As repreensões do governo às organizações populares fizeram com que as desigualdades crescessem ainda mais, o que refletiu nas metrópoles e nas suas "múltiplas periferias" em expansão mais do que nunca:

O golpe de 1964 representou a emergência de um poder autoritário que, ao controlar e reprimir as organizações populares, transformou a metrópole num locus, mais do que nunca, ditado pela lógica do lucro, investindo massivamente para acelerar a acumulação do capital e privilegiando os estratos mais ricos da população. Mais do que nunca, São Paulo tornou-se uma cidade segregada, pois as políticas públicas foram canalizadas para uma transformação urbana que beneficiou as camadas de médio e alto poder aquisitivo, ao mesmo tempo em que continuavam a se reproduzir as múltiplas periferias desprovidas de serviços básicos em que as favelas, até então quantitativamente insignificantes em São Paulo, passaram a crescer aceleradamente (BONDUKI, KOWARICK, 1994, p. 148).

As políticas públicas implantadas durante o governo militar através do Banco Nacional de Habitação e o Serviço Federal de Habitação e Urbanismo - SERFHAU não foram eficazes para melhorar a vida dos trabalhadores nas periferias nem para conter o aumento da desigualdade social, estimulando, inclusive, o aumento dessas desigualdades.

O SERFHAU teve como principal atividade entre 1966 e 1970 incentivar os municípios a formularem planos locais de desenvolvimento integrado com os recursos do BNH. À princípio, esses planos diretores eram para ser feitos a partir de uma ótica regional e não municipal, segundo a lógica que se desenhava no Plano Decenal, mas isto não aconteceu, segundo Lucchese e Rossetto (2018), por falta de aparato jurídico para organizações regionais. Além disso, os milhares de Planos que foram feitos não tiveram efetividade e nenhum tipo de participação da população mais necessitada (LUCCHESE, ROSSETO, 2018).

As políticas urbanas do $\mathrm{BNH}$, por sua vez, alteraram as relações de trabalho ao criar o Fundo de Garantia por Tempo de Serviço e obter desse fundo grande volume de recursos para as suas obras (RODRIGUES, 2011). Foram financiadas cerca de 4,5 milhões de 
unidades habitacionais, mas apenas $16 \%$ dos investimentos do Banco que eram obtidos a partir dos salários dos trabalhadores, foram direcionados às famílias com até cinco salários mínios. A negligência do Estado com a parcela mais pobre da população tornase ainda mais evidente ao se considerar que, do conjunto do Sistema Financeiro de Habitação (SFH), cujos recursos advêm do FGTS e das Cadernetas de Poupança, apenas $4 \%$ de suas enormes fontes foram canalizadas para esses trabalhadores (KOWARICK, BONDUKI, 1994; MARICATO, 1987; RODRIGUES, SEABRA, 1986).

Na capital paulista, cenário de muitas casas autoconstruídas, favelas, cortiços e demais tipos de residências precárias, a COHAB - Companhia Metropolitana de Habitação de São Paulo, agente promotor do $\mathrm{BNH}^{26}$, também não produziu moradias suficientes para as famílias com renda inferior a cinco salários mínimos, que em São Paulo representava cerca de dois terços da população. De sua fundação em 1965 até 1991, havia produzido apenas 109 mil unidades, quantidade muito inferior à de pessoas que necessitavam de moradia, cuja maioria delas sequer podia ter acesso aos financiamentos de habitação (KOWARICK; BONDUKI, 1994; ROCHENZEL, 1986).

Enquanto os recursos para os projetos de habitação caíram de 1969 a 1976, os programas de desenvolvimento urbano - voltados para saneamento, transportes, urbanização e equipamentos comunitários, bem como para fundos regionais de desenvolvimento urbano e os polos econômicos -, tiveram um aumento no repasse de verbas (MARICATO, 1987). Além da relação com o planejamento e as discussões regionais que abordamos no capítulo anterior, essa priorização tem relação direta com uma disputa entre as empresas de edificação e da construção pesada, onde as segundas se sobrepuseram (op. cit.).

Nesse sentido, somente a partir das graves insuficiências do slogan do "milagre econômico" explica-se que, em um contexto de repreensão e censura, estes anos não transcorreram sem lutas e resistências, sendo uma parte importante dessas reivindicações por melhorias das condições urbanas nas periferias das grandes cidades.

É certo que as resistências aconteciam também dentro do local de trabalho, já que mesmo nos anos mais repressivos, não deixaram de existir reinvindicações, atos de

\footnotetext{
${ }^{26}$ Outra crítica ao BNH é que a produção em larga escala desconsiderou as diversidades regionais, culturais, sociais e económicas do país, aspectos a serem levados em conta na adoção de alternativas tecnológicas, na concepção de projetos e na escolha de materiais e de processos de trabalho (KAUPATEZ, 1986).
} 
sabotagem, quebra de máquinas e ferramentas e diversos tipos de operação tartaruga (ABRAMO, 1994). No entanto, com o bloqueio dos canais institucionais pelo regime como sindicatos e partidos políticos, é nas periferias que os movimentos populares vão continuar se organizando, e vão ter na Igreja, por meio das Comunidades Eclesiais de Base - CEBs, uma grande aliada nessas lutas (BRANT, 1982).

As lutas que vão se organizar na década de 1970 nas periferias não eram simples substituições às organizações fabris e sindicais (KOWARICK, BONDUKI, 1994). Tratavam-se de mobilizações que respondiam a uma realidade urbana e periférica surgida de uma dinâmica de acumulação do capital e de um tipo de planejamento urbano que fazia vistas grossas às condições de vida precárias dos trabalhadores. Ao mesmo tempo, o poder público não economizava nos investimentos em vias expressas, pontes, viadutos e na abertura de novas avenidas, como aconteceu a partir da administração Faria Lima (196569) em São Paulo (op. cit.), bem como nos grandes empreendimentos construídos em diferentes áreas do país à nível federal.

A formação das Comunidades Eclesiais de Base tem início nos primeiros anos da década de 1960. Desde então, era vista como um movimento de baixo para cima de demanda de participação dos leigos no interior da Igreja Católica no Brasil e, ao mesmo tempo, um movimento de cima para baixo, de uma Igreja que precisava se expandir e se fortalecer diante do crescimento de outras religiões. Após 1965, quando os bispos brasileiros aprovaram o Plano Pastoral de Conjunto para o quinquênio 1966-1970, foi expressa a vontade da CNBB de que uma Igreja renovada viesse a surgir das comunidades de base. Assim, em um contexto de autoritarismo e crescimento da pobreza nas cidades, os bispos que estavam mais preocupados com as consequências sociais do evangelho buscaram construir em suas dioceses uma Igreja que estivesse ao lado dos pobres, aumentando, dessa maneira, o número de CEBs (CAMARGO et. al., 1982).

Em São Paulo, as CEBs podem ter se inspirado nas experiências das SABs, criadas na década de 1930, mesmo que estas estivessem muitas vezes interessadas em barganhas com o Estado. De acordo com Singer (1982), as CEBs agiam de início “para dentro”, ou seja, viam a necessidade de criar uma nova consciência e uma mentalidade de união, buscando a "ajuda-mútua" nos Clubes de Mães, grupos de reflexão, cursos, compras em comum etc. Em seguida, os problemas mais urgentes da periferia metropolitana, como saneamento, iluminação segurança, calçamento, saúde etc. se transformaram em reivindicações "para fora". 
Uma dessas reinvindicações ocorreu em torno dos loteamentos clandestinos em meados dos anos 1970, com o apoio da Comissão da Pastoral da Periferia de Santo Amaro e dos advogados dos Centros Acadêmicos 11 de Agosto da USP e 22 de agosto da PUC. A insatisfação decorria dos loteamentos populares em São Paulo serem feitos apenas segundo os interesses dos loteadores, sem nenhuma legislação que os regulamentasse, tanto nos aspectos urbanísticos que previssem uma infraestrutura mínima, quanto nos aspectos legais que estabelecessem que a estrutura fundiária devesse ser legalizada (GOHN, 2004; SINGER, 1982).

Outro movimento ocorrido a partir das CEBs foi o do Custo de Vida que se destaca pelo fato de ter sido protagonizado por mulheres moradoras da periferia. Em 1973, os Clubes de Mães da Paróquia de Vila Remo resolveram escrever uma carta às autoridades reclamando dos custos de vida e dos altos preços dos alimentos nos bairros da periferia. Dessa ação, o movimento realizou enquetes para saber as consequências da carestia sobre o padrão de vida das pessoas, o que resultou na elaboração de um abaixo assinado com mais de 1 milhão de assinaturas que foi levado a Brasília. Em 1977, o movimento passa por uma reorientação e mudanças na condução política, passando a se denominar Movimento Contra a Carestia. Assim, os encontros são retomados, sendo que setecentos delegados de comunidades se encontraram para firmar uma coordenação geral e responder à questão: por que sobe o custo de vida e por que os salários não acompanham essa elevação? Em janeiro de 1979, é realizado o $1^{\circ}$ Encontro Nacional Contra a Carestia, que contou com mais de 200 representantes de vários estados do Brasil (SINGER, 1982).

Fora esses movimentos que vão surgindo de maneira "organizada", aconteceram também os quebra-quebras de ônibus e trens no Rio de Janeiro e em São Paulo em 1974. Esses movimentos espontâneos não podem ser entendidos fora do contexto urbano que se projetava no período e sem considerar o dia-a-dia dos sujeitos envolvidos. Percorrendo longas distâncias no trajeto da casa (precária) para o trabalho, os trabalhadores estavam revoltados em perder horas (da vida e) do trabalho em função dos atrasos gerados pela precariedade dos transportes públicos. Enquanto as frotas dos transportes individuais se multiplicaram por nove de 1960 a 1974, o investimento em transporte público estancava. Somava-se ao medo de se atrasar, a preocupação com mortes de pingentes, 
descarrilamentos, colisões etc. Assim, a aparente espontaneidade das ações de revolta não pode ser comparada a uma falta de lógica (MOYSES et. al., 1985 ${ }^{27}$ ).

Do início ao fim do regime militar houve diferentes graus de repreensão e controle político. Os relativos afrouxamentos no nível de endurecimento do regime se deram, sobretudo, como uma resposta à pressão exercida pelos trabalhadores, dentro de uma perspectiva da luta de classes. Essas revoltas aconteceram inclusive após o AI5 decretado em 1968, mesmo que de forma isolada, e vão ganhar ainda mais força no final da década de 1970 com a Lei da Anistia e o reestabelecimento do pluripartidarismo (BRANT, 1982).

Essas ações contrárias à ditadura militar influenciaram e foram influenciadas pelas eleições de 1974, quando o Movimento Democrático Brasileiro - MDB consegue uma importante representação parlamentar, tornando-se ainda mais expressiva em 1978. Com o aumento da pressão popular, a Arena, que governava o Estado de São Paulo, não podia mais ignorar as reivindicações da classe trabalhadora e precisava minimizar o caráter excludente das políticas públicas para vencer eleições. Assim, há a criação de um Programa de Saneamento em 1975 e uma nova postura em relação as favelas, optando-se pela sua não remoção (KOWARICK, BONDUKI, 1994). Disso, tiramos que

...o contexto da chamada reabertura política não constituiu mero esgotamento do período ditatorial, seja porque o regime tivesse cumprido seus objetivos, seja porque tivesse renunciado ao arbítrio como meio de atingi-los. Ele revela na verdade a disposição do governo de adaptar-se a uma realidade social que escapa ao poder de previsão dos estados-maiores e dos gabinetes tecnocráticos. Essa disposição não se antecipa a uma crise, ela surge com atraso do reconhecimento dessa "crise", ou seja, do reconhecimento generalizado de que a sociedade reorganizou-se à margem das pautas previstas para enquadrá-la (BRANT, 1982, p. 25).

O ano de 1978 não foi só marcante na trajetória da AGB, mas também para outros sujeitos, como os movimentos grevistas, que marcaram a história do $\mathrm{ABC}$ paulista, região que havia sido fortemente afetada pela chegada das indústrias automobilísticas. Foi neste ano que os operários da Scania, insatisfeitos com suas condições salariais, entraram na fábrica e se recusaram a trabalhar. A postura do Sindicato dos Metalúrgicos de São Bernardo e Diadema e do seu líder Luís Inácio Lula da Silva durante as campanhas salariais foi fundamental para que, somente entre maio e dezembro de 1978, fossem organizadas 328 greves (SECCO, 2011).

\footnotetext{
${ }^{27}$ Essa obra foi censurada durante a ditadura militar.
} 
As novas lutas sindicais que despontaram em 1978 não estavam isoladas das lutas que haviam despontado nas periferias, não apenas porque os baixos salários das fábricas levavam os trabalhadores a contestar a vida em áreas mais distantes e sem a infraestrutura, mas também porque

[...] o novo sindicalismo era auxiliado por uma extensa rede comunitária dos bairros onde moravam os trabalhadores e suas famílias. Os piquetes não se limitavam às portas de fábrica e eram feitos nos pontos de ônibus; os encontros se davam em bares e as reuniões, proibidas pela polícia, acabam na Igreja Católica. O estádio de futebol de Vila Euclides, onde Lula discursava para milhares de pessoas sem o apoio de aparelhagem de som, simbolizou o espírito de comunhão daqueles operários (SECCO, 2011, p. 40).

Estes grupos mais atuantes do movimento sindical em combinação com outros movimentos sociais deram origem a algumas das principais entidades populares que posteriormente contribuíram para a reconstrução da democracia no país, como o Partido dos Trabalhadores, a Central Única dos Trabalhadores, o Movimento dos Trabalhadores Sem Terra e a Central de Movimentos Populares (LADKSKY; OLIVEIRA, 2014).

O Partido dos Trabalhadores, oficializado em 1980, tinha como base mais importante depois dos operários das multinacionais e do sindicalismo, a Igreja Católica por meio das Comunidades Eclesiais de Base. A retomada do movimento estudantil também forneceu militantes ao PT, como foi o caso do Rio de Janeiro, onde a maioria das adesões veio de líderes estudantis (SECCO, 2011).

Em relação ao movimento estudantil, seu último grande furor havia sido em 1968, no Congresso de Ibiúna, que acabou com repressão militar. A partir de então, com o surgimento de outras entidades estudantis e acompanhando o movimento da sociedade, houve a refundação da União Nacional dos Estudantes em 1979 (ANTUNES, 2001). A retomada da luta ocorreu na noite de 22 de setembro de 1977, quando o campus da PUC de São Paulo foi invadido pela Polícia Militar devido ao fato de ali ter acontecido o III Encontro Nacional de Estudantes (ENE), cujo objetivo maior era reorganizar a UNE (SECCO, 2011).

Nesse momento, uma parte importante geógrafos não estava alheia a esse processo de ampliação da desigualdade social do país, ao aumento das mazelas nas periferias das grandes cidades, às ações do Estado na área da habitação que não amenizavam o problema da moradia para os mais pobres e nem mesmo às várias lutas que aconteciam nas periferias e em defesa da democracia. Os conflitos que aconteceram nos ENGs ao longo 
de toda a década de 1970 e a busca incessante por uma geografia crítica, capaz de analisar criticamente a realidade social, apontam para essa nova postura dos geógrafos em nosso país.

Como veremos, a geografia urbana crítica ainda não estava totalmente amadurecida nesse período, já que a década de 1970 representou para os geógrafos um momento de renovação e reestruturação das bases teórico-metodológicas da ciência. No entanto, já despontavam trabalhos pioneiros na área, conforme temos apontado nessa pesquisa e, de acordo Abreu (1994) o Encontro de 1978, além de todo o seu peso histórico, foi também palco de importantes avaliações sobre a geografia urbana no Brasil que chegaram a ser publicadas.

A partir de meados da década de 1980, as publicações a partir de uma geografia urbana crítica aumentaram e instrumentalizaram uma importante atuação dos geógrafos e da AGB no apoio às lutas urbanas e à reforma urbana no Brasil. A entidade, por meio dos seus geógrafos mais engajados, elaboraria junto aos movimentos populares urbanos e aos sujeitos que estavam mobilizados, dentro daquele "caldeirão" de lutas que estavam sendo travadas, uma emenda popular pela reforma urbana que seria enviada ao Congresso Constituinte.

Por outro lado, haviam os geógrafos que estavam às voltas com a geografia quantitativa, a outra vertente de renovação da Geografia que se expandia no Brasil na década de 1970. As análises estavam voltadas para as práticas de planejamento que aconteciam no IBGE e estavam em plena atividade durante esse momento.

\subsection{IBGE: números e regiões metropolitanas}

Em meio a todos as reivindicações da classe trabalhadora por condições dignas de salários, menores custos de vida e melhorias nos espaços urbanos e periféricos; bem como de diversos setores da sociedade que exigiam a abertura democrática no país, o IBGE se mantinha a todo vapor na elaboração de políticas de planejamento.

Em 1968, quando Marilia Velloso Galvão assume a última gestão da Divisão de Geografia do CNG - o IBGE seria depois transformado em Fundação -, foi criado o Grupo de Áreas Metropolitanas - GAM, coordenado por Speridião Faissol, após a saída 
de Lysia Bernardes ${ }^{28}$ para continuar a carreira de planejadora no IPEA $^{29}$. Na condução dessas pesquisas sobre processo de metropolização, Faissol escancarou as portas do IBGE para a geografia quantitativa (ALMEIDA, 2000).

Essa imersão de Faissol na abordagem da geografia quantitativa pode ser explicada pelo seu contato com o geógrafo Brian Berry e o economista e planejador John Friedman, que tinham também trabalhado no SERFHAU, no Rio de Janeiro. Mais tarde, o também geógrafo John Cole chegaria ao Brasil e seria um grande responsável pela introdução da geografia quantitativa no IBGE, influenciando também os trabalhos de Faissol (ALMEIDA, 2000; GEIGER, 1988).

As técnicas e teorias da geografia quantitativa foram muito discutidas entre os ibegeanos e os professores de Rio Claro, que se tornou um polo difusor dessas ideias no interior de São Paulo. A Revista "Geografia Teorética" era a porta-voz da teoria na UNESP. Ainda dentro do contexto universitário, o curso de mestrado em Geografia na UFRJ, criado em 1972, incorporou disciplinas de técnicas quantitativas, que tiveram como professores além de Faissol, Olga Buarque de Lima, quando retornou de seu mestrado em Nottingham, Roberto Lobato Corrêa, quando retornou seu mestrado em Chicago e Maurício de Almeida Abreu, quando retornou de seu doutorado em Ohio (ALMEIDA, 2000).

Em 1973, durante o governo de Emílio G. Médici, foram criadas as Regiões Metropolitanas de Porto Alegre, Curitiba, São Paulo, Rio de Janeiro, Belo Horizonte, Salvador, Recife, Fortaleza e Belém. A criação das áreas levou em consideração os estudos realizados pelo GAM ${ }^{30}$. Em 1969, Marília Velloso Galvão, Speridião Faissol, Olga Maria Buarque de Lima e Elisa Maria José Mendes de Almeida publicaram um texto na RBG que serviria de base para essa política. O texto foi denominado "Áreas de Pesquisa para Determinação de Áreas Metropolitanas”, onde se propunha o estudo e a aplicação "de critérios para identificação e delimitação de áreas de pesquisa, sobre as quais deverá ser feito um levantamento estatístico especial no Censo de 1970, para fins de determinação das áreas metropolitanas do país” (v. 31, n. 4, p. 52). Interessante resgatar também que as primeiras discussões sobre regiões metropolitanas, mesmo que tímidas, ocorreram na Assembleia Anual da AGB de Viçosa em 1959, sendo depois

\footnotetext{
${ }^{28}$ Lysia depois trabalharia no governo do Rio de Janeiro e, em seguida, no Ministério do Interior, como Secretária Geral da Secretaria Especial da Região Sudeste (SERSE) (ALMEIDA, 2000).

${ }^{29}$ Em 1967, o EPEA transformou-se em IPEA, o Instituto de Pesquisa Econômica Aplicada.

${ }^{30}$ Outras instituições se envolveram nos estudos sobre as regiões metropolitanas, como o Ipea e o Serfhau.
} 
desenvolvidas em diversos trabalhos e muito incentivadas por Maria Therezinha de Segadas Soares (ABREU, 1994), reforçando as relações entre esses espaços.

Por fim ${ }^{31}$, destaca-se nessa breve retrospectiva do trabalho do geógrafo na área do planejamento regional/territorial, o II Plano Nacional de Desenvolvimento - PND (19751979), que foi coordenado pelo Ministério do Planejamento e Coordenação Geral, em épocas sombrias da gestão do presidente Ernesto Geisel. Faremos algumas breves considerações sobre o II Plano e o Capítulo IV, denominado "Desenvolvimento Urbano, Controle da Poluição e Preservação do Meio Ambiente", em função da participação de geógrafos em seus estudos e em seus desdobramentos.

\subsubsection{PND e o capítulo da Política Urbana}

O II PND, em parte, foi uma continuidade de ideias que apareceram no Plano Decenal e também no I PND (1971-1974). Dentro de uma perspectiva interdisciplinar, sobretudo envolvendo economistas e arquitetos, os estudos que resultaram nesses planos tiveram muitas contribuições do IBGE e de seus geógrafos, das publicações da Revista Brasileira de Geografia e das pesquisas em Geografia (e da geografia urbana) que estavam disponíveis na época.

Queremos destacar neste tópico alguns aspectos do capítulo IV do II PND. Este capítulo foi baseado em um grande estudo que resultou na elaboração da Política Nacional de Desenvolvimento Urbano - PNDU, coordenado pelo arquiteto Jorge Guilherme Francisconi e pela geógrafa Maria Adélia de Souza (foto 4). A PNDU teve a contribuição de outros profissionais e instituições, como foi o caso do IBGE, por meio de nomes como Speridião Faissol, Roberto Lobato Correa, Maria do Carmo Correa Galvão e Lysia Bernardes (SOUZA, 2010).

Maria Adélia de Souza ${ }^{32}$ foi a primeira professora de Planejamento do Departamento de Geografia da USP, em 1970. Foi também membro da Sagmacs Sociedade para Análise Gráfica e Mecanográfica Aplicada aos Complexos Sociais, instituição de planejamento urbano na França, fundada pelo padre Louis J. Lebret.

\footnotetext{
${ }^{31}$ No final da década de 1970, o IBGE os geógrafos foram perdendo seus papeis de planejadores, e em função de uma "obsessão técnica", o Instituto também deixou de ser palco de reflexões teóricas, que se deslocariam definitivamente para as universidades (FAISSOL, 1988; BOMFIM, 2007).

${ }^{32}$ Tendo sido orientada por Celso Furtado e Michel Rochefort na pós-graduação realizada na França, trabalhou também no SERFHAU e foi professora da Faculdade de Arquitetura e Urbanismo da USP.
} 


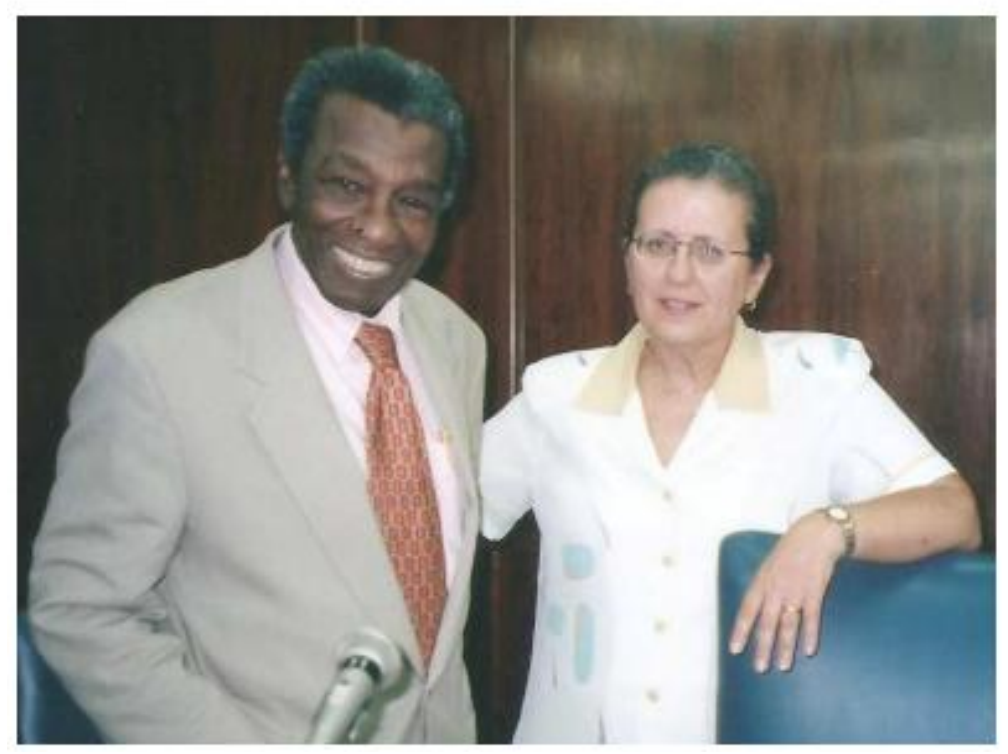

Foto 4: Geógrafa Maria Adélia ao lado de Milton Santos. Fonte: Arquivo pessoal de Maria Adélia de Souza.

De acordo com a geógrafa, havia uma contradição entre o II Plano e a redação do capítulo IV, na medida em que aquele reforçava a concentração de investimentos na região Centro-Sul do país, enquanto que a Política Nacional de Desenvolvimento Urbano, que fundamentou o capítulo IV...

....ao definir áreas de intervenção, labora sobre a possibilidade de promover a contenção, o controle, e a dinamização nas diferentes áreas, ajustando-as às estratégias de desenvolvimento urbano específicas para cada uma delas, conforme objetivos de desenvolvimento geral perseguidos para as grandes regiões do país com o intuito de minimizar as desigualdades regionais (SOUZA, 2010, p. 118).

Com essas contradições e, logicamente, pelos limites do próprio planejamento, o Plano ficou bastante inviabilizado. No entanto, a autora aponta para os desdobramentos desse trabalho, como a indicação de um Programa de Cidades Médias, que seria em tese um instrumento de descentralização de investimentos no território brasileiro. Em relação a este Programa e os seus fundamentos, Souza relata:

O problema de concentração e de crescimento do eixo Rio-São Paulo, que naquele tempo produzia $85 \%$ do PIB brasileiro. Ele só vai parar de crescer aceleradamente e, a teremos problemas cada vez maiores de atendimentos quanto as demandas por equipamentos de serviços públicos urbanos - chegava a 1 milhão de pessoas por ano naquele tempo - se for possível o controle dos migrantes brasileiros, la nas regiões de emigração. Então é por isso que era preciso fazer uma política nacional urbana. Daí, eu tive a ideia de criar um Programa de Cidades Médias para ver se a gente conseguia atrair, para elas, investimentos, pois se não tiver empresa e gente investindo, você não cria empregos. Então, o Programa de Cidades Médias foi muito bem recebido pelos empresários e, por isso, ele foi implantado e a gente 
conseguiu muito dinheiro não só para a atividade produtiva, mas os Governos Federal e Municipal também investiram para dotar a cidade de equipamentos e serviços de interesse coletivo: água e esgoto, asfalto, coleta de lixo (Maria Adélia Souza em entrevista a Larissa Araujo em novembro de 2019).

O Programa de Cidades de Porte Médio foi aplicado em 1976 e vigorou durante dez anos (STEINBERGER; BRUNA, 2001). Essa política foi criada pela Comissão Nacional de Regiões Metropolitanas e Política Urbana - CNPU, um órgão que surgiu em 1974 em consequência dos estudos para o capítulo da Política Urbana. No entanto, Souza faz uma crítica à política que foi implantada por sua "visão setorialista do urbano". Em outras palavras, as ações políticas eram "estabelecidas com base nos setores (transporte urbano, saneamento, drenagem), e não nos lugares numa perspectiva de promoção do desenvolvimento da totalidade do território urbano brasileiro" $(2010$, p. 118).

É importante ressaltar que, embora as regiões metropolitanas apareçam citadas no capítulo da Política Urbana (II PND, 1974), não houve uma ligação direta entre o estudo que serviu de base ao texto e a implantação das regiões metropolitanas em 1973, embora tenham acontecido no mesmo período, expressando mais um conflito de interesses que para Adélia se dá entre as "ações urbanas e as políticas de interesse da população brasileira" (Entrevista de Maria Adélia concedida a Larissa Araujo em novembro de 2019).

Não é intenção dessa reflexão e dessa pesquisa negar o planejamento em suas diferentes escalas de atuação nem mesmo minimizar a importância dos trabalhos que foram feitos no Brasil. A pesquisa tem como propósito, justamente, resgatar a atuação dos geógrafos e geógrafas e do papel da Geografia nos conflitos e debates que envolvem o espaço urbano, trazendo uma narrativa que coloque esses sujeitos e instituições em evidência, num contexto em que outras áreas do conhecimento têm uma espécie de "monopólio" desses relatos.

No entanto, apesar de reconhecer o potencial que os planejamentos urbanos, regionais e territoriais possuem - e que variam de acordo com o lugar e o contexto -, pensamos ser necessário colocar algumas das inúmeras contradições em evidência, mesmo que esses apontamentos sejam um esboço de uma análise que requer uma profunda reflexão.

O primeiro aspecto a destacar sobre essa prática foi o contexto de autoritarismo que se deu a maior parte das ações em planejamento, tanto no governo de Getúlio Vargas, e sobretudo, ao longo dos mais de vinte anos do regime militar. É certo que muitos técnicos 
do planejamento das diferentes áreas que trabalharam sob essa condição autoritária e repreensiva não coadunavam com as atrocidades cometidas pelas autoridades, inclusive contra as universidades (como relatamos acima). Alguns mais progressistas atuavam, inclusive, nas "brechas" do regime, apesar das grandes limitações e contradições que essa condição impõe. No entanto, o planejamento praticado por esses sujeitos não deixa de estar encharcado pela lógica autoritária, pois falamos de estudos que eram transformados em políticas implantadas de cima para baixo, sem considerar a opinião da população e sobretudo da classe trabalhadora, que mais necessita das políticas públicas. Em certa instância, nem mesmo os pareceres técnicos eram totalmente imprescindíveis, já que o campo político forjou uma autonomia que se sobrepõe a qualquer grupo ou ideia.

Como lembrou Bonfim (2007), o discurso do planejamento é uma "ideologia geográfica”, expressão de Moraes (1996) para designar as representações e discursos acerca da relação espaço/sociedade, que legitimam os interesses do Estado e de outros sujeitos. No contex to que estamos estudando, esse discurso tentava convencer a eficiência de um governo que planejava e construía, inclusive moradias pelo Banco Nacional de Habitação, mas não impedia o aumento da desigualdade social. Era um discurso imbuído mais ou menos da crença de que o "planejamento tinha algo de sagrado e por isso neutro, e que carregava em si todos os méritos para transformar as cidades brasileiras" (LUCCHESE, ROSSETTO, 2018, p. 41).

Mesmo as posições mais progressistas entre os "pensadores" do território, sobretudo os geógrafos, que objetivavam diminuir as desigualdades e que viam o espaço como um "espaço social", ou "do uso", invisibilizavam a classe trabalhadora, os sindicatos, os movimentos sociais etc. Disso levantamos um segundo ponto, que é a forma de análise desses técnicos e suas abordagens. Nestes estudos, muitas vezes a questão migratória ou demográfica foram vistas como os principais problemas que levavam às desigualdades regionais, deixando de lado as desigualdades à nível de classe, que foram aumentando porque além das dinâmicas impostas pelo capital, as lutas não podiam acontecer e os salários não foram acompanhando as inflações, as necessidades de moradia etc. Como afirmou Regina Célia B. dos Santos (1996), o aumento da população de baixa renda não acontece apenas por causa do crescimento vegetativo e migratório, porque isso poderia ser resolvido com programas de planejamento familiar ou de contenção da migração. É a pauperização da classe trabalhadora que contribuiu enormemente para o aumento da população de baixa renda. 
A falta de moradia das pessoas de baixa renda, consequência da pauperização dessa parcela da população, justificou algumas práticas de planejamento urbano, como a política setorial de habitação promovida pelo BNH. As análises sobre essas ações muitas vezes também são distorcidas, pois os conflitos são vistos como problemas de consumo, descolados da esfera do trabalho. Como coloca Rodrigues (2013), é do mundo do trabalho que saiu a maior parte dos recursos utilizados para a modernização da economia prevista no I e II PND. Isso porque a maioria dos recursos vinha do $\mathrm{BNH}$, por meio do Fundo de Garantia de Tempo de Serviço - FGTS, criado em $1966^{33}$. Para a autora, trata-se da

[...] socialização capitalista da exploração da força de trabalho. Permitiu ao Estado investir na produção e modernização do espaço urbano. Deslocou os conflitos do mundo do trabalho para o mundo do consumo [...]. O Estado assumiu os embates entre os trabalhadores $\mathrm{e}$ empregadores e a política urbana, baseada num planejamento econômico, tem como alicerce a política setorial de habitação com recursos provenientes das transformações das relações de trabalho (RODRIGUES, 2013, p. 215).

Além da contraditória condição do trabalhador que "financiava" as políticas urbanas que não o atendia, podemos pensar em como "o planejamento urbano fica refém da política econômica, mascarado com a ideia de política social da produção de moradias populares" (RODRIGUES, 2013, p. 215). Nesse sentido, Rochenzel (1986) diz também que, apesar do peso que a questão demográfica tinha em algumas análises do planejamento, não é o acréscimo de população que determina o ritmo e a intensidade das construções de casas, já que esse acréscimo populacional é contínuo e o número de construções parece variar de acordo com o movimento inflacionário, ou seja, quanto este se eleva o número de construções também.

A partir dessas observações, colocamos um terceiro ponto que é a limitação do planejamento em si. Não é possível que as práticas sejam harmônicas, pois atendem às correlações de forças de cada lugar, do contexto de cada período, dos financiamentos disponíveis e estão vinculadas a uma totalidade (RODRIGUES, 2013). Rodrigues (2013), apoiada em Poulantzas (1987), coloca que o planejamento está vinculado aos interesses dos setores dominantes fora e dentro dos aparelhos estatais, caracterizando-se por uma política classista. Porém, acrescenta que

\footnotetext{
${ }^{33}$ Da mesma forma, Rodrigues (2016) aponta que a possibilidade do Programa Minha Casa Minha Vida em 2009 se vincula ao aumento geral do emprego, ou seja, ao aumento de recursos do FGTS. Ou seja, esse deslocamento dos conflitos do mundo do trabalho para o mundo do consumo está presente em momentos mais ou menos democráticos.
} 
[...] o Estado não é monolítico, sendo permeado por conflitos internos que materializam a condensação de lutas de classes, portanto as contradições estão presentes tanto fora do sistema político estatal, como no interior do Estado e não separado da sociedade civil (RODRIGUES, 2013, p. 208)

Dessa maneira, mesmo em uma realidade em que o econômico se sobrepõe ao social, existiram lutas e vão continuar existindo, lutas estas que acumularam conquistas e esbarram em muitas limitações e que vão continuar sendo base para as lutas que estão por vir.

Ainda de acordo com Rodrigues (2013), o planejamento contraditoriamente funciona como um "desvio" da realidade, na medida em que chama a atenção para o técnico e retira o foco do conteúdo, mesmo quando discutido e reivindicado pelos movimentos sociais e a classe trabalhadora. A autora coloca o caso da função social da propriedade que aparece na Constituição de 1988 após muita luta. Em sua origem, a função social tem como objetivo impedir que a terra urbana fique sujeita aos interesses da propriedade privada e do mercado, mas como este princípio ficou condicionado ao Plano Diretor pela Constituição, houve um "aprisionamento" do seu real significado e um retrocesso nas disputas com os interesses hegemônicos. Outro exemplo é o Plano Diretor Participativo, que aparece no Estatuto da Cidade e que tem sido duvidosa a sua efetividade. Assim, "critica-se a forma como o planejamento tem sido realizado, mas não o seu conteúdo". (op. cit., p. 217).

Um quarto e último aspecto que queremos ressaltar é baseado nas colocações de Francisco de Oliveira em “Crítica à Razão Dualista" (2013) e nos remeteremos para isso aos anos 1950. De acordo com o autor, os conceitos de "integração nacional”, "interesse nacional" e "planejamento" estão associados à teoria do subdesenvolvimento desenvolvida pela CEPAL - Comissão Econômica para a América Latina e o Caribe ${ }^{34}$, que é a base do "desenvolvimentismo" no país.

Para a CEPAL, o subdesenvolvimento da América Latina não era explicado apenas pela colonização mercantilista da região, mas também pelo interesse dos países do centro em manter os países em desenvolvimento como exportadores de bens primários. Nesse sentido, seus integrantes apostavam no nacionalismo, ou seja, no desenvolvimento

\footnotetext{
${ }^{34}$ A CEPAL foi criada em 1948 pelo Conselho Econômico e Social da Organização das Nações Unidas ONU com o objetivo de incentivar a cooperação econômica entre os seus membros. Entre seus integrantes estavam Celso Furtado e Raul Prebisch.
} 
econômico como resultado de uma revolução nacional e capitalista e da adoção de uma estratégia nacional de desenvolvimento (PEREIRA, 2010). Dessa maneira, planejar e integrar o território seriam os caminhos para chegar nessa realidade de maior industrialização e modernização do país.

Aponta-se a ideia de Oliveira para ampliar, ainda que em um esboço, as disputas ideológicas daquele período, mostrando que além das diferentes escalas de análise que lidamos até agora e que influenciam modos de agir e pensar, muitos técnicos, pesquisadores e políticos consideravam também a relação centro-periferia do capitalismo mundial, o que de acordo, com Oliveira (2013, p. 33), fez com que

[...] toda a questão do desenvolvimento foi vista pelo ângulo das relações externas, e o problema transformou-se assim em uma oposição entre nações, passando desapercebido o fato de que, antes de oposição entre nações, o desenvolvimento ou o crescimento é um problema que diz respeito à oposição entre classes sociais internas.

Por outro lado, Pereira (2010) coloca que sobretudo após a Revolução Cubana em 1959, as esquerdas da América Latina foram perdendo de vista a ideia de nação, o que enfraqueceu também os partidos políticos de esquerda até os anos 2000.

Assim, observa-se que existia uma relação entre o planejamento territorial contido nas políticas aplicadas durante as décadas de 1950 e 1960 no Brasil e as teorias econômicas existentes no período ${ }^{35}$. Como afirmamos acima, apesar das críticas que fizemos, não é intenção desse trabalho descartar nenhuma perspectiva, mas suscitar elementos para que os geógrafos e as geógrafas busquem caminhos teóricos e métodos de atuação sobre e sob o urbano, a partir de uma abordagem crítica.

\subsection{A cidade e o urbano nos boletins da AGB}

Conforme relatamos, a análise dos boletins incluiu também no caso do BPG os editorais, que são ricos para perceber os posicionamentos da Seção de São Paulo no que diz respeito aos contextos vividos ao longo de sua publicação e as próprias crises vividas internamente pela Geografia. O BCG não possuía o mesmo formato de boletim, portanto não fizemos a análise dos editorais. Os dois boletins têm diferenças no tempo de

\footnotetext{
${ }^{35}$ A tese de Bonfim (2007) dá importantes contribuições sobre essas relações.
} 
existência, nas comissões responsáveis e na organização interna, o que influenciou na forma de análise do conteúdo de cada revista.

O contexto implicado pela ditadura militar, que dificultava a realização de eventos dentro das universidades na década de 1970 devido à censura, pode também ter afetado a escrita dos editoriais do BPG. Percebe-se que a AGB São Paulo pouco se posicionou contra as condições daquele período. A primeira menção vai acontecer no editorial da edição de número 55, no ano 1978, data do ENG de Fortaleza (figura 4). Nele, a Comissão Editorial se coloca favorável à campanha pela reintegração da vida acadêmica dos professores afastados compulsoriamente de suas atividades nas universidades e instituições de pesquisa no contexto dos atos institucionais. O próximo (e último) editorial a se posicionar de forma contundente a favor da redemocratização foi o da edição de número 60, no ano de 1982. A Comissão Editorial retoma a participação da AGB na luta pelas Diretas Já e de alguns eventos de importância não apenas acadêmica para a entidade, mas também política, como foi o caso do V ENG ocorrido em Porto Alegre e o $1^{\circ}$ Encontro de Professores de Geografia do Estado de São Paulo. Também é feita uma homenagem aos boias-frias que se revoltaram contra as condições de trabalho nas regiões açucareiras do interior de São Paulo, num movimento que ficou conhecido como a Revolta de Guariba.

Como visto, essa realidade era o pano de fundo para os embates entre a geografia crítica e a geografia quantitativa ao longo do período, o que sem sombra de dúvidas afetava as produções e publicações científicas. No entanto, a geografia quantitativa ou o neopositivismo não ganhou espaço nas publicações dos Boletins Paulistas de Geografia devido ao baixo envolvimento dos geógrafos de São Paulo com essa linha de pesquisa. Depois da geografia tradicional, é a geografia crítica que mais vai influenciar os estudos sobre a cidade e o urbano que são publicados no BPG, o que vai acontecer de maneira crescente no decorrer da década de 1970 e tomar uma dimensão maior na década de 1980. 
Figura 4 - Editorial da edição nº 55 do BPG do ano de 1978

\section{EDITORIAL}

Juntamente com outras parcelas da população, os cientistas no Brasil têm sido vítimas, principalmente após 1964 , do modelo e conômico e político vigente no país. Com efeito, atravës dos̄ chamados "atos institucionais", as autoridades governamentais perseguiram, demitiram e aposentaram grande nümero de professo res e cientistas das nossas universidades e instituições de pesquisa.

"A campanha pela reintegração na vida acadêmica dos pro. fessores dela afastados compulsoriamente por força dos atos dé exceção constitui momento importante na luta mais ampla pela democratização da sociedade e da Universidade, pela restaura ção da dignidade das instituições de ensino superior no Brasil̄ e pela sua reestruturação como órgãos livres de ensino, pesqui sa, reflexão crítica e debate." Assim se inicia O Livro Negro da USP -- O Controle Ideológico na Universidade, obra publicada pela ADUSP e que representa mais uma denúncia das arbitrarieda des perpetradas pelo Governo brasileiro contra o conjunto da comunidade científica no Brasil.

E importante lembrar que o descaso e as hostilidades para com a cultura e a ciência neste país não são um privilëgio des se regime. Ao conträrio, tal atitude tem sido uma constante no comportamento da classe dominante ao longo da nossa história, classe essa profundamente autoritāria e cujas "aberturas polí ticas" sempre foram passageiras e duvidosas.

Neste momento, en que se denuncia e en que toda a socieda de brasileira toma conhecimento das iniquj.dades $\mathrm{j} \vec{a}$. cometidas, $\vec{e}$ dever de todas as entidades científicas somarem-se à campanha de reintegração dos professores e cientistas arbitrariamente removidos de suas funções, a exemplo do que jă fez a Associação dos Docentes da Universidade de São Paulo (ADUSP); é nosso de ver participar desse movimento e defender a readmissão de nos sos mestres e colegas e a imediata criação das necessärias conn dições de trabalho, para que eles possam ser verdadeiramente reintegrados na comunidade cientifica do país.

\section{A Comissão Redatoria1}

Fonte: Site da AGB São Paulo.

De acordo com Abreu (1994), a repreensão militar e a oposição da geografia quantitativa amenizaram os debates da geografia urbana crítica no ENG de Belo Horizonte em 1976, que não foram publicados. Porém, os reflexos dessas discussões foram sentidos no ENG de Fortaleza dois anos depois: 
Os debates travados em Belo Horizonte não foram publicados, talvez porque a Crítica ao neopositivismo associou-se, como era de se esperar, a uma crítica maior, ainda sujeita a censura, e que tinha como alvo o regime militar então em vigor. Foi um início tímido, mas que haveria de produzir frutos rapidamente, desembocando no grande fórum de debates que representou a Sessão Dirigida sobre "A Geografia Urbana no Brasil - Uma Avaliação", realizada dois anos depois em Fortaleza sob a coordenação de Roberto Lobato Corrêa (Associação dos Geógrafos Brasileiros, 1978) (ABREU, 1994, p. 58).

Depois de Fortaleza, por outro lado:

Se os debates urbanos tiveram importância nessa fase inicial de implantação da Geografia Crítica no Brasil, há que se reconhecer, entretanto que, logo após Fortaleza, eles entraram numa fase de recesso, consequência imediata da prioridade que se passou a dar à reflexão teórica mais ampla, de caráter teórico-epistemológico, necessária para a afirmação da nova proposta que surgia (ABREU, 1994, p. 58).

Dessa maneira, a produção em geografia urbana entre os anos de 1978 e 1983 não foi muito intensa, porque era um tempo de "arrumação da casa" (ou da ciência). Nesse momento de organização das ideias, merece destaque o nome de Ariovaldo Umbelino de Oliveira que, com seu estudo de 1978 sobre a lógica da especulação imobiliária, inaugura esta nova forma de pensar o espaço urbano (ABREU, 1994).

As mudanças na forma de abordar o urbano refletem as renovações teóricas e metodológicas na Geografia. Nas edições do Boletim Paulista essa discussão vai se esboçar com sinais mais fortes a partir de 1976, com o editorial que levava o título "Por que mudar?". A mudança referida não era apenas na diagramação e na introdução de novas seções nos boletins, mas também na apresentação do BPG como um espaço de autocrítica da Geografia. Dessa maneira, chama a atenção o fato de que os boletins da AGB - SP, enquanto veículo, tiveram um importante papel na divulgação das geografias críticas, tão importantes naquele momento para compreender e intervir na realidade. Nas palavras de Myrna Viana, que assina esse editorial:

O debate amplo de ideias, a crítica e a autocrítica, tão importante para o desenvolvimento de todas as ciências, custam a se transformar numa prática de geógrafos, especialmente dos geógrafos brasileiros. Nem mesmo os resultados científicos são difundidos com rapidez. Evidentemente muitas são as causas para que tal não aconteça e muitas são as dificuldades para que a ciência geográfica deverá chegar até chegar a um maior amadurecimento. Acreditamos, entretanto, que uma das limitações para a superação dessas dificuldades é a inexistência de uma publicação em que essas ideias possam ser expostas e debatidas (Editorial do boletim de n 51, ano 1976 da AGB São Paulo). 
Se nesse editorial o BPG se coloca como um veículo da crise, em 1977 a crise na Geografia é escancarada:

Nunca, como nos dias de hoje, tornou-se tão clara a consciência da compreensão do espaço para, inclusive, se propor soluções para o desenvolvimento nacional. Levanta-se até a necessidade de criação de novas disciplinas: Espaciologia, Ciência Regional, uma Nova Geografia. Preocupações desse tipo mostram interesse pelo objeto de conhecimento que, numa divisão de trabalho científico, caberia à Geografia. No entanto, mostram também o desconhecimento da disciplina chamada Geografia. E isso deve ser objeto de preocupação, porque talvez indique uma das causas da debilidade científica dos geógrafos e a pequena contribuição que estes têm dado ao desenvolvimento da teoria e dos métodos científicos, elementos distintos, mas indissociáveis (Editorial do boletim de n ${ }^{\circ}$ 54, ano de 1977 da AGB São Paulo).

Nesse mesmo editorial é lançado o desafio para os geógrafos interessados na discussão do "problema". Na própria edição Manuel Correia de Andrade assina o artigo “O pensamento geográfico e a realidade brasileira", onde escreve sobre o surgimento da geografia quantitativa no Brasil - o qual estabelece uma ligação com a criação do IBGE e a necessidade de repensar novos caminhos para a Geografia, como o método dialético proposto por David Harvey e considerando saberes produzidos in lócus tanto por geógrafos como por não geógrafos. Outros textos publicados no boletim vão marcar bastante esse esforço de reconhecimento da crise e de tentativa de renovação da ciência, como “A geografia está em crise. Viva a geografia!", escrito por Carlos Walter Porto Gonçalves na edição 55 de 1978 e "Para que a geografia mude sem ficar a mesma coisa", escrito por Milton Santos em 1982 na edição de número 59.

Abaixo analisamos as publicações de geografia urbana no BPG (quadro 3) e no BCG (quadro 4) na década de 1970. Destacamos aquelas que estão mais próximas da geografia crítica, a qual tratamos nesse momento por "geografia qualitativa" (RODRIGUES, 2004) por entendermos que os estudos ainda estavam em processo de amadurecimento, sem ainda uma estruturação bem consolidada (ABREU, 1994) e destacamos também os artigos que estavam mais alinhados com a geografia quantitativa. 
Quadro 3 - Publicações sobre a cidade e o urbano no BPG (Década de 1970)

Legenda:

Geografia Qualitativa

Geografia Quantitativa

\begin{tabular}{|c|c|c|c|}
\hline Título do artigo & Autor (a) & $\mathbf{N}^{\mathbf{o}}$ & Ano \\
\hline Uma vila do litoral paulista - Icapara & Nice Lecoq Muller & 1 & 1949 \\
\hline Oxford, cidade de ontem e de hoje & Nice Lecoq Muller & 2 & 1949 \\
\hline A "vila" de Itanhaém & José Ribeiro de Araujo Filho & 6 & 1950 \\
\hline A cidade de Olímpia & E. Goulart Pereira de Araujo & 9 & 1951 \\
\hline $\begin{array}{l}\text { As paisagens humanizadas da ilha de } \\
\text { São Sebastião }\end{array}$ & Ary França & & \\
\hline $\begin{array}{l}\text { Aspectos geográficos e problemas da } \\
\text { região de Corumbataí }\end{array}$ & Pasquale Petrone & 11 & 1952 \\
\hline $\begin{array}{l}\text { As indústrias paulistanas e os fatores } \\
\text { da expansão }\end{array}$ & Pasquale Petrone & 14 & 1953 \\
\hline $\begin{array}{l}\text { Aspectos geográficos do crescimento } \\
\text { da cidade de São Paulo }\end{array}$ & Pierre Monbeig & 16 & 1954 \\
\hline $\begin{array}{l}\text { Ensaio de geografia urbana de New } \\
\text { York }\end{array}$ & Pierre Deffontaines & 17 & 1954 \\
\hline $\begin{array}{l}\text { Contribuição à geografia urbana de } \\
\text { Nagoia }\end{array}$ & Kanji Kagami & 18 & 1954 \\
\hline $\begin{array}{l}\text { Porto Alegre, metrópole do Brasil } \\
\text { meridional }\end{array}$ & Jean Roche & 19 & 1955 \\
\hline Crato, "capital" da região do Cariri & Pasquale Petrone & 20 & 1955 \\
\hline $\begin{array}{l}\text { Contribuição ao estudo do norte do } \\
\text { Paraná }\end{array}$ & Nice Lecoq Muller & 22 & 1956 \\
\hline O homem paulista & Pasquale Petrone & 23 & 1956 \\
\hline $\begin{array}{l}\text { Ponta Grossa, capital regional do } \\
\text { oeste do Paraná }\end{array}$ & Elina O. Santos & 24 & 1956 \\
\hline Embriões de Cidades Brasileiras & Aroldo de Azevedo & 25 & 1957 \\
\hline $\begin{array}{l}\text { Rua da Consolação, uma das artérias } \\
\text { da capital paulista }\end{array}$ & José Domingos Tírico & 29 & 1958 \\
\hline $\begin{array}{l}\text { Aix-Em-Provence, uma cidade do } \\
\text { mediterrâneo francês }\end{array}$ & Antônio Rocha Penteado & 30 & 1958 \\
\hline A circulação urbana & Michel Tabuteau & 31 & 1959 \\
\hline $\begin{array}{l}\text { Contribuição ao estudo dos centros de } \\
\text { cidades: o exemplo da cidade de } \\
\text { Salvador }\end{array}$ & Milton Santos & 32 & 1959 \\
\hline $\begin{array}{l}\text { Características e tendências } \\
\text { principais das migrações internas } \\
\text { no Brasil, nas suas relações com a } \\
\text { urbanização e a industrialização }\end{array}$ & José Francisco de Camargo & 33 & 1959 \\
\hline
\end{tabular}




\begin{tabular}{|c|c|c|c|}
\hline $\begin{array}{l}\text { Brazzaville: alguns aspectos de } \\
\text { uma cidade da África francesa }\end{array}$ & Pierre Vennetier & 34 & 1960 \\
\hline Sousas, subúrbios de Campinas & José Domingos Tirico & 35 & 1960 \\
\hline $\begin{array}{l}\text { Aspectos dos quadros urbanos da } \\
\text { Baixada Do Ribeira, SP }\end{array}$ & Pasquale Petrone & 38 & 1961 \\
\hline $\begin{array}{l}\text { O sítio urbano de Porto Alegre: } \\
\text { estudo geográfico }\end{array}$ & Aziz Nacib Ab'Saber & 42 & 1965 \\
\hline $\begin{array}{l}\text { Experiências de colonização em } \\
\text { uma área tropical: A Baixada da } \\
\text { Ribeira }\end{array}$ & Pasquale Petrone & 42 & 1965 \\
\hline $\begin{array}{l}\text { Contribuição ao estudo da indústria } \\
\text { têxtil de Americana (Estado De } \\
\text { São Paulo) }\end{array}$ & Helmut Troppmair & 43 & 1966 \\
\hline $\begin{array}{l}\text { Paraná: o quadro geográfico, } \\
\text { histórico e econômico do processo } \\
\text { de urbanização }\end{array}$ & Maria Adélia A. de Souza & 46 & 1971 \\
\hline $\begin{array}{l}\text { Os núcleos de colonização oficial } \\
\text { implantados no planalto paulistano } \\
\text { em fins do século XIX }\end{array}$ & Juerge Richard Langenbuch & 46 & 1971 \\
\hline O bairro industrial do Jaguaré, SP & $\begin{array}{l}\text { Léa Goldenstein, Rosa Ester } \\
\text { Rossini }\end{array}$ & 47 & 1972 \\
\hline $\begin{array}{l}\text { Características do espaço } \\
\text { econômico industrial }\end{array}$ & Armando Corrêa da Silva & 48 & 1973 \\
\hline $\begin{array}{l}\text { Os centros industriais do Estado } \\
\text { São Paulo }\end{array}$ & Beatriz Maria Soares Pontes & 49 & 1974 \\
\hline $\begin{array}{l}\text { O processo de industrialização em } \\
\text { São Paulo }\end{array}$ & Armen Mamigonian & 50 & 1976 \\
\hline $\begin{array}{l}\text { Regionalização: tema geográfico e } \\
\text { político - o caso paulista }\end{array}$ & Maria Adélia de Souza & 50 & 1976 \\
\hline $\begin{array}{l}\text { Desenvolvimento econômico e } \\
\text { urbanização em países } \\
\text { subdesenvolvidos: os dois sistemas } \\
\text { de fluxo da economia urbana e suas } \\
\text { implicações espaciais }\end{array}$ & Milton Santos & 53 & 1977 \\
\hline $\begin{array}{l}\text { Desenvolvimento de comunidade } \\
\text { no processo de urbanização: notas } \\
\text { para uma crítica das teorias } \\
\text { sociológicas do planejamento }\end{array}$ & Henrique Rattner & 54 & 1977 \\
\hline $\begin{array}{l}\text { A planificação do desenvolvimento } \\
\text { de regiões atrasadas }\end{array}$ & Henrique Rattner & 56 & 1979 \\
\hline Geografia e Planejamento & Horieste Gomes & 61 & 1984 \\
\hline $\begin{array}{l}\text { Paradigma e movimento social: por } \\
\text { onde andam nossas ideias? }\end{array}$ & $\begin{array}{l}\text { L. A. Machado da Silva, Ana } \\
\text { Clara T. Ribeiro }\end{array}$ & 62 & 1985 \\
\hline $\begin{array}{l}\text { Estado, Divisão Social do Trabalho } \\
\text { e Habitação }\end{array}$ & José Antônio Ronchezel & 64 & 1986 \\
\hline
\end{tabular}




\begin{tabular}{|c|c|c|c|}
\hline $\begin{array}{l}\text { Habitação e Espaço Social na } \\
\text { Cidade de São Paulo }\end{array}$ & $\begin{array}{l}\text { Arlete Moysés Rodrigues, } \\
\text { Manoel Seabra }\end{array}$ & 64 & 1986 \\
\hline $\begin{array}{lrrr}\text { As condições } & \text { de } & \text { existência de } \\
\text { parcelas } & \text { da } & \text { população } \\
\text { trabalhadora: } & \text { a } & \text { questão da } \\
\text { habitação } & & & \end{array}$ & Regina Célia Bega dos Santos & 64 & 1986 \\
\hline $\begin{array}{l}\text { Cubatão: na busca das favelas e o } \\
\text { encontro do "peão" que permanece }\end{array}$ & Amélia Luisa Damiani & 64 & 1986 \\
\hline \begin{tabular}{l}
\multicolumn{3}{l}{ Situação habitacional no Brasil e a } \\
utilização de processos de \\
autoajuda e ajuda-mútua na \\
produção de moradias
\end{tabular} & Ros Mari Zenha Kaupatez & 64 & 1986 \\
\hline $\begin{array}{l}\text { Indústria da construção - reflexão } \\
\text { sobre o "atraso tecnológico" }\end{array}$ & Ermínia Maricato & 64 & 1986 \\
\hline $\begin{array}{l}\text { Passado e presente das relações } \\
\text { entre sociedade e espaço e } \\
\text { localização pontual da indústria } \\
\text { moderna no Estado da Bahia }\end{array}$ & Milton Santos & 65 & 1987 \\
\hline $\begin{array}{l}\text { Os shopping-center brasileiros e o } \\
\text { processo de valorização do espaço } \\
\text { urbano }\end{array}$ & Silvana Maria Pintaudi & 65 & 1987 \\
\hline $\begin{array}{l}\text { Terceirização } \\
\text { metropolitano }\end{array}$ & $\begin{array}{l}\text { Christian Dennis Monteiro de } \\
\text { Oliveira }\end{array}$ & 65 & 1987 \\
\hline $\begin{array}{l}\text { A intervenção do estado nas } \\
\text { transformações do espaço urbano - } \\
\text { caso Cura em Cuiabá }\end{array}$ & $\begin{array}{l}\text { Cornélio Silvano Vilarinho } \\
\text { Neto }\end{array}$ & 65 & 1987 \\
\hline $\begin{array}{l}\text { Mudanças nas formas de comércio } \\
\text { varejista e a implantação dos } \\
\text { supermercados na Grande São } \\
\text { Paulo - SP - Brasil }\end{array}$ & Silvana Maria Pintaudi & 66 & 1988 \\
\hline $\begin{array}{l}\text { O processo de terceirização do } \\
\text { espaço metropolitano: um estudo } \\
\text { sobre sua realização na regional } \\
\text { administrativa de Santo Amaro - } \\
\text { São Paulo }\end{array}$ & $\begin{array}{l}\text { Christian Dennys Monteiro de } \\
\text { Oliveira }\end{array}$ & 66 & 1988 \\
\hline $\begin{array}{l}\text { Mapeamento das causas de morte } \\
\text { no município de São Paulo: } \\
\text { Subsídios de uma Geografia } \\
\text { Médica da cidade }\end{array}$ & Helena Ribeiro Sobral & 66 & 1988 \\
\hline $\begin{array}{l}\text { Pensando o processo } \\
\text { valorização e a Geografia }\end{array}$ & $\begin{array}{llll}\text { Odette } & \text { Carvalho de Lima } \\
\text { Seabra } & & & \end{array}$ & 66 & 1988 \\
\hline $\begin{array}{l}\text { Migrações, Urbanização e o Setor } \\
\text { Informal: Estudo sobre as Formas } \\
\text { de Comercialização em Área de } \\
\text { Emigração para as Metrópoles de } \\
\text { São Paulo e Rio de Janeiro (Brasil) }\end{array}$ & Nilson Crocia de Barros & 66 & 1988 \\
\hline
\end{tabular}




\begin{tabular}{|l|l|l|l|}
\hline Paraná que se acaba? & $\begin{array}{l}\text { Denise Rockenbach, Glória da } \\
\text { Anunciação Alves }\end{array}$ & 66 & 1988 \\
\hline $\begin{array}{l}\text { Materiais para o estudo da } \\
\text { urbanização brasileira no período } \\
\text { técnico científico }\end{array}$ & Milton Santos & 67 & 1989 \\
\hline Bixiga: uma ideologia geográfica & Francisco Capuano Scarlato & 67 & 1989 \\
\hline
\end{tabular}

Organizado pela autora. Fonte: AGB - São Paulo.

As publicações em geografia urbana no BPG mostram uma mudança importante no de 1973. No ano anterior, Léa Goldenstein e Rosa Ester Rossini analisaram o bairro do Jaguaré da cidade de São Paulo, dentro de uma abordagem local, próxima daquela das monografias urbanas. A partir de então os artigos passam a tratar de relações, processos e fluxos, seguindo a linha de alguns trabalhos que já vinham sendo realizados de maneira mais pontual (ABREU, 1994). De acordo com Abreu (1994, p. 53), essas alterações mais presentes surgiram com uma "vinculação dos estudos de padrão, tão ao gosto dos geógrafos, a referenciais processuais maiores. Relacionar processo social e forma espacial, eis, agora, a palavra de ordem desta Geografia que se renovava".

Destacamos aqui o trabalho de Armen Mamigonian, que já na década de 1960 inovava dentro da hegemonia de uma geografia tradicional ao escrever no BCG sobre a indústria e suas consequências para o espaço e para a vida urbana em Santa Catarina. Em 1976, no boletim $n^{\circ}$ 50, dedicou-se a estudar o processo de industrialização na cidade de São Paulo. Não é à toa que Ariovaldo de Oliveira o identifica como o primeiro geógrafo marxista do Brasil (Ariovaldo de Oliveira em entrevista ao BPG, 2008).

No entanto, a geografia urbana crítica ainda estava vivendo seu próprio processo na década de 1970, à mercê de uma reestruturação mais ampla das bases teóricometodológicas da Geografia, e temas como as lutas dos movimentos sociais e a questão da moradia só vão aparecer no BPG em meados da década de 1980.

Por outro lado, não há publicações em geografia urbana à luz da geografia quantitativa no BPG. Tal ausência se justifica pela pouca vinculação que a Geografia de São Paulo e da USP teve com essa abordagem, fortemente presente no Rio de Janeiro e em Rio Claro - SP. 
Quadro 4 - Publicações sobre a cidade e o urbano no BCG (Década de 1970)

Legenda:

Geografia Qualitativa

Geografia Quantitativa

\begin{tabular}{|c|c|c|c|c|}
\hline Título do artigo & Autor & $\mathbf{N}^{\mathbf{0}}$ & Vol & Ano \\
\hline Função Regional de Formosa & Lucio de Castro Soares & 2 & I & 1948 \\
\hline Região Centro-Ocidental da Bahia & Alfredo J. P. Domingues & 3 & $\mathrm{I}$ & 1948 \\
\hline Uma Viagem ao Planalto Central & Speridião Faissol & 5 e 6 & I & 1948 \\
\hline $\begin{array}{l}\text { Duas Vilas no Estado de Santa } \\
\text { Catarina }\end{array}$ & Victor Peluso Jr & 5 e 6 & I & 1948 \\
\hline $\begin{array}{lll}\text { Aspectos } & \text { Geográficos do } & \text { Bas } \\
\text { Languedoe: } & \text { Região de Montpellier }\end{array}$ & Elza Coelho de Sousa & 5 e 6 & $\mathrm{I}$ & 1948 \\
\hline $\begin{array}{l}\text { Contribuição ao Estudo da Ocupação } \\
\text { Humana do Território do Amapá }\end{array}$ & Lúcio de Castro Soares & 2 e 3 & I & 1948 \\
\hline $\begin{array}{l}\text { As Veredas e os Gerais na região do } \\
\text { Rio Preto na Bahia (estudo de } \\
\text { geografia humana) }\end{array}$ & Pedro Geiger & 1 & III & 1950 \\
\hline $\begin{array}{l}\text { Notas Sobre a Cidade de Diamantina } \\
\text { e seus Habitantes }\end{array}$ & $\begin{array}{l}\text { Lysia Maria Cavalcante } \\
\text { Bernardes }\end{array}$ & 2 e 3 & III & 1950 \\
\hline A Colonização no Estado de Goiás & Speridião Faissol & 2 e 3 & III & 1950 \\
\hline $\begin{array}{l}\text { A Cidade de Cruzeiro - Notas de } \\
\text { Geografia Urbana }\end{array}$ & Nilo Bernardes & 1 e 2 & $\mathrm{~V}$ & 1952 \\
\hline $\begin{array}{l}\text { Notas para o Estudo do Núcleo } \\
\text { Colonial de Santa Cruz (Secção de } \\
\text { Piranema) }\end{array}$ & $\begin{array}{ll}\text { Delnida } & \text { Martinez } \\
\text { Alonso } & \end{array}$ & 1 e 2 & VIII & 1955 \\
\hline $\begin{array}{l}\text { Reconhecimento Geográfico no } \\
\text { Município de Pompéu, M.G. }\end{array}$ & Orlando Valverde & 1 e 2 & VIII & 1955 \\
\hline $\begin{array}{l}\text { Análise preliminar dos tipos de } \\
\text { povoamento no } \\
\text { principalmente sob o ponto de vista } \\
\text { de sua morfologia }\end{array}$ & $\begin{array}{l}\text { José Veríssimo da Costa } \\
\text { Pereira }\end{array}$ & 3 e 4 & VIII & 1955 \\
\hline $\begin{array}{l}\text { Contrastes Regionais da terra norte - } \\
\text { americana }\end{array}$ & $\begin{array}{l}\text { José Veríssimo da Costa } \\
\text { Pereira }\end{array}$ & 3 e 4 & VIII & 1955 \\
\hline $\begin{array}{l}\text { Vargem Grande (alguns aspectos } \\
\text { geográficos) }\end{array}$ & Amélia Alba Nogueira & 1 e 2 & IX & 1956 \\
\hline $\begin{array}{l}\text { Origem e evolução urbana de } \\
\text { Garanhuns }\end{array}$ & Hilton Sette & 1 e 2 & IX & 1956 \\
\hline $\begin{array}{l}\text { Exemplos de hierarquia de cidades no } \\
\text { Brasil }\end{array}$ & Pedro Pinchas Geiger & 3 e 4 & $\mathrm{X}$ & 1957 \\
\hline $\begin{array}{l}\text { A respeito de "Mapas econômicos das } \\
\text { cidades e regiões do Rio de Janeiro e } \\
\text { São Paulo }\end{array}$ & $\begin{array}{l}\text { Michel Blochu e Pedro } \\
\text { Pinchas Geiger }\end{array}$ & 3 e 4 & $\mathrm{X}$ & 1957 \\
\hline
\end{tabular}




\begin{tabular}{|c|c|c|c|c|}
\hline $\begin{array}{l}\text { Santa Teresa, um bairro residencial } \\
\text { no centro do Rio de Janeiro }\end{array}$ & $\begin{array}{lr}\text { Aluízio } & \text { Peixoto } \\
\text { Boynarde e } & \text { Maria } \\
\text { Thereza Soares } & \\
\end{array}$ & 1 e 2 & $\mathrm{XI}$ & 1958 \\
\hline $\begin{array}{l}\text { Alguns problemas sugeridos pelo } \\
\text { estudo da colonização alemã no Rio } \\
\text { Grande do Sul }\end{array}$ & Jean Roche & 1 e 2 & $\mathrm{XI}$ & 1958 \\
\hline A primeira vila portuguesa no Brasil & M. T. de Segadas Soares & $1 \mathrm{e} 2$ & $\mathrm{XI}$ & 1958 \\
\hline $\begin{array}{l}\text { O conceito geográfico de bairro e sua } \\
\text { exemplificação na cidade do Rio de } \\
\text { Janeiro }\end{array}$ & M. T. de Segadas Soares & 3 e 4 & $\mathrm{XI}$ & 1958 \\
\hline $\begin{array}{l}\text { Tipos de Localização de Cidades em } \\
\text { Pernambuco }\end{array}$ & Mário Lacerda de Melo & 3 e 4 & $\mathrm{XI}$ & 1958 \\
\hline $\begin{array}{l}\text { Evolução da paisagem urbana do Rio } \\
\text { de Janeiro até o início do século XX }\end{array}$ & $\begin{array}{l}\text { Lysia Maria Cavalcante } \\
\text { Bernardes }\end{array}$ & 1 e 2 & XII & 1959 \\
\hline $\begin{array}{l}\text { Notas de viagem à Costa do Marfim: } \\
\text { economia comercial e transformações } \\
\text { da paisagem geográfica na A. O. F. }\end{array}$ & Milton Santos & $1 \mathrm{e} 2$ & XII & 1959 \\
\hline $\begin{array}{l}\text { Meditação geográfica sobre o Rio de } \\
\text { Janeiro }\end{array}$ & Pierre Deffontaines & 3 e 4 & XII & 1959 \\
\hline $\begin{array}{l}\text { A organização urbana da Amazônia } \\
\text { Brasileira }\end{array}$ & Michel Rochefort & 3 e 4 & XII & 1959 \\
\hline $\begin{array}{l}\text { Função defensiva do Rio de Janeiro e } \\
\text { seu sítio original }\end{array}$ & $\begin{array}{l}\text { Lysia Maria Cavalcante } \\
\text { Bernardes }\end{array}$ & 1 e 2 & XIII & 1960 \\
\hline $\begin{array}{l}\text { Notas sobre a região de Ponte Nova e } \\
\text { Viçosa }\end{array}$ & Michel Tabutlau & 1 e 2 & XIII & 1960 \\
\hline $\begin{array}{l}\text { A Indústria em Brusque (Santa } \\
\text { Catarina) e suas consequências sobre } \\
\text { a vida urbana }\end{array}$ & Armen Mamigonian & 3 e 4 & XIII & 1960 \\
\hline $\begin{array}{l}\text { O problema da classificação do } \\
\text { habitat }\end{array}$ & Michel Rochefort & 1 e 2 & XIV & 1961 \\
\hline $\begin{array}{l}\text { Uma experiência de colonização na } \\
\text { Baixada Fluminense }\end{array}$ & Roberto Lobato Corrêa & 1 & $\mathrm{XV}$ & 1962 \\
\hline $\begin{array}{l}\text { Aracajú, síntese de Geografia } \\
\text { Humana }\end{array}$ & $\begin{array}{l}\text { José Alexandre Felizola } \\
\text { Diniz }\end{array}$ & 1 & XV & 1962 \\
\hline $\begin{array}{l}\text { Alguns problemas das grandes } \\
\text { cidades nos países subdesenvolvidos }\end{array}$ & Milton Santos & 1 & XV & 1962 \\
\hline $\begin{array}{l}\text { Madureira }- \text { Tentativa de } \\
\text { determinação da área de influência de } \\
\text { um sub-centro da metrópole carioca }\end{array}$ & $\begin{array}{l}\text { Maria Francisca Tereza } \\
\text { Cavalcanti Cardoso e } \\
\text { Maria Emilia Teixeira } \\
\text { de Castro Botelho }\end{array}$ & 1 & $\begin{array}{l}\text { XVI } \\
\text { I }\end{array}$ & $\begin{array}{l}1965 / 1 \\
966\end{array}$ \\
\hline $\begin{array}{l}\text { As causas do crescimento recente de } \\
\text { Itaboraí - Vendas das Pedras }\end{array}$ & $\begin{array}{l}\text { Mauricio de Almeida } \\
\text { Abreu e Maria do } \\
\text { Socorro Diniz }\end{array}$ & 1 & XXI & 1970 \\
\hline $\begin{array}{l}\text { Relações entre o Desenvolvimento } \\
\text { Econômico Regional e o Sistema } \\
\text { Urbano - O caso do Chile }\end{array}$ & Brian J. L. Berry & 1 & XXI & 1970 \\
\hline Regionalização - análise Quantitativa & Speridião Faissol & 1 & XXI & 1970 \\
\hline
\end{tabular}




\begin{tabular}{|c|c|c|c|c|}
\hline $\begin{array}{l}\text { Uma Medida da Função de Direção } \\
\text { das Cidades Brasileiras }\end{array}$ & $\begin{array}{l}\text { Ruth Lopes da Cruz } \\
\text { Magnanini e Olga Maria } \\
\text { Buarque de Lima }\end{array}$ & 1 & $\begin{array}{l}\text { XXI } \\
\text { I }\end{array}$ & 1971 \\
\hline $\begin{array}{l}\text { Analise Fatorial de } 3 \text { áreas } \\
\text { Metropolitanas - Belo Horizonte, } \\
\text { Curitiba e Porto Alegre }\end{array}$ & $\begin{array}{llr}\text { Elisa Mendes } & \text { de } \\
\text { Almeida e Olga } & \text { Maria } \\
\text { Buarque de Lima }\end{array}$ & 1 & $\begin{array}{l}\text { XXI } \\
\mathrm{I}\end{array}$ & 1971 \\
\hline $\begin{array}{l}\text { A Política de Desenvolvimento } \\
\text { Urbano no Processo de } \\
\text { Desenvolvimento Nacional }\end{array}$ & Zila Mesquita Melo & 1 & $\begin{array}{l}\text { XXI } \\
\mathrm{I}\end{array}$ & 1971 \\
\hline $\begin{array}{l}\text { Contribuição ao Estudo da Estrutura } \\
\text { Interna da Área Metropolitana do Rio } \\
\text { de Janeiro. O caso de Xerém (Duque } \\
\text { de Caxias) }\end{array}$ & \begin{tabular}{llr} 
Gilda & \multicolumn{2}{c|}{ Campos } \\
Impellizieri & de $\quad \mathrm{S}$. \\
Martins & &
\end{tabular} & 1 & $\begin{array}{l}\text { XXI } \\
\text { I }\end{array}$ & 1971 \\
\hline $\begin{array}{l}\text { A Rede de Localidades Centrais do } \\
\text { Rio Grande do Sul, determinada } \\
\text { através da Teoria dos Grafos }\end{array}$ & Maria do Socorro Diniz & 1 & $\begin{array}{l}\text { XXI } \\
\mathrm{I}\end{array}$ & 1971 \\
\hline $\begin{array}{l}\text { Um Aspecto da Urbanização no } \\
\text { Estado do Espírito Santo }\end{array}$ & Maria do Socorro Diniz & 1 & $\begin{array}{l}\text { XXI } \\
\text { I }\end{array}$ & 1971 \\
\hline $\begin{array}{l}\text { Notas sobre aplicações de Modelo } \\
\text { Probabilístico de Distribuição Poison } \\
\text { ao Sistema Urbano }\end{array}$ & $\begin{array}{l}\text { Pedro Pinchas } \text { Geiger, } \\
\text { Joao Rua e Luiz } \\
\text { Antonio Ribeiro }\end{array}$ & 1 & $\begin{array}{l}\text { XXI } \\
\text { I }\end{array}$ & 1971 \\
\hline $\begin{array}{l}\text { Integração de Maricá à área } \\
\text { metropolitana do Rio de Janeiro }\end{array}$ & $\begin{array}{l}\text { Marlene Teixeira e } \\
\text { William G. Soares }\end{array}$ & 1, & $\begin{array}{l}\text { XXI } \\
\text { V }\end{array}$ & $\begin{array}{l}1973 / 1 \\
974 / 19 \\
75\end{array}$ \\
\hline $\begin{array}{l}\text { O processo de urbanização no } \\
\text { continente africano }\end{array}$ & $\begin{array}{l}\text { Iná Elias de Castro, } \\
\text { Naria Helena Lacorte e } \\
\text { Nelza Araújo }\end{array}$ & 1 & $\begin{array}{l}\mathrm{XX} \\
\mathrm{V}\end{array}$ & 1976 \\
\hline O Povoamento do Nordeste & Hilda da Silva & 2 & $\begin{array}{l}\mathrm{XX} \\
\mathrm{VI}\end{array}$ & 1976 \\
\hline O Sistema Urbano do Nordeste & Hilda da Silva & 2 & $\begin{array}{l}\text { XX } \\
\text { VI }\end{array}$ & 1976 \\
\hline $\begin{array}{l}\text { Mudanças de população: um estudo } \\
\text { de pequenas cidades nos estados do } \\
\text { Maranhão, Pernambuco e São Paulo } \\
\text { no Brasil }\end{array}$ & Hilda da Silva & 2 & $\begin{array}{l}\text { XX } \\
\text { VI }\end{array}$ & 1976 \\
\hline $\begin{array}{l}\text { A natureza da política habitacional } \\
\text { para grupos de baixa e média renda no } \\
\text { Rio de Janeiro e seus efeitos no } \\
\text { modelo residencial da referida cidade }\end{array}$ & Hilda da Silva & 2 & $\begin{array}{l}\text { XX } \\
\text { VI }\end{array}$ & 1976 \\
\hline Divisão Regional do Brasil & $\begin{array}{l}\text { Fábio Macedo Soares } \\
\text { Guimarães }\end{array}$ & 1 & $\begin{array}{l}\text { XX } \\
\text { VII }\end{array}$ & $\begin{array}{l}1977 / 1 \\
978\end{array}$ \\
\hline $\begin{array}{ll}\text { Desequilíbrios } & \text { regionais- } \\
\text { formulações teóricas } & \\
\end{array}$ & $\begin{array}{l}\text { Maria Francisca } \\
\text { Thereza C. Cardoso }\end{array}$ & 1 & $\begin{array}{l}\text { XX } \\
\text { VII }\end{array}$ & $\begin{array}{l}1977 / 1 \\
978\end{array}$ \\
\hline $\begin{array}{l}\text { Análise de critérios de população na } \\
\text { identificação de zonas internas na } \\
\text { região metropolitana do Rio de } \\
\text { Janeiro }\end{array}$ & $\begin{array}{l}\text { Haidina da S. B. Duarte } \\
\text { e William Gonçalves } \\
\text { Soares }\end{array}$ & 1 & $\begin{array}{l}\text { XX } \\
\text { VII }\end{array}$ & $\begin{array}{l}1977 / 1 \\
978\end{array}$ \\
\hline $\begin{array}{l}\text { Urbanização e migração na Amazônia } \\
\text { Legal: sugestão para uma abordagem } \\
\text { geopolítica }\end{array}$ & Lia Osório Machado & 1 & $\begin{array}{l}\text { XX } \\
\text { XII }\end{array}$ & 1982 \\
\hline
\end{tabular}




\begin{tabular}{|l|l|l|l|l|}
\hline $\begin{array}{l}\text { Organização do espaço e organização } \\
\text { social: o caso de Rondônia }\end{array}$ & Milton Santos & 1, & $\begin{array}{l}\text { XX } \\
\text { XII }\end{array}$ & 1982 \\
\hline $\begin{array}{l}\text { Carajás: processo decisório e impacto } \\
\text { espacial }\end{array}$ & $\begin{array}{l}\text { Maria Célia Nunes } \\
\text { Coelho e Raymundo } \\
\text { Garcia Cota }\end{array}$ & 1 & $\begin{array}{l}\text { XX } \\
\text { XII }\end{array}$ & 1982 \\
\hline
\end{tabular}

Organizado pela autora. Fonte: AGB - Rio de Janeiro.

As publicações influenciadas pela geografia pragmática ou quantitativa, como esperado, estão muito presentes no BCG, refletindo uma forte influência das pesquisas e atividades desenvolvidas no IBGE, conforme analisado nesse capítulo. Nesse sentido, os artigos publicados a partir dessa abordagem têm um viés voltado para o planejamento, reforçando a ideia de que a introdução da geografia quantitativa no Brasil teve o objetivo de instrumentalizar as práticas dos geógrafos nas instituições de planejamento.

Os estudos sobre a metrópole também vão aparecer sobre o prisma da quantitativa, o que se deveu à influência de Speridião Faissol, geógrafo que estudou a implantação das regiões metropolitanas no IBGE e que foi um propagador dessa perspectiva da Geografia no Brasil. Dessa maneira, o boletim n. 1, v. XXII, de 1971, é representativo dessa abordagem, já que entre outros artigos que servem de exemplos, podemos citar o que foi escrito por Elisa Mendes de Almeida e Olga Buarque de Lima: "Análise Fatorial de Três Áreas Metropolitanas - Belo Horizonte, Curitiba e Porto Alegre”.

O boletim de volume XXVI, número 2, foi uma publicação em homenagem à geógrafa Hilda da Silva. Hilda estudou em Chicago, o que explica a influência do método quantitativo em seus trabalhos, inclusive dos que foram publicados no BCG em 1976, com a exceção de "Mudanças de população: um estudo de pequenas cidades nos estados do Maranhão, Pernambuco e São Paulo no Brasil”. Este último estava mais próximo das monografias urbanas, que foram amplamente publicadas na década de 1950 (BCG, 1976). Apesar de sua formação, achamos importante destacar a preocupação da autora com as políticas habitacionais naquele ano, mostrando que mesmo dentro da geografia quantitativa haviam os geógrafos que estavam também buscando compreender e analisar o problema da moradia que estava posto naquele momento, mesmo que essa preocupação só venha a se tornar expressiva na década de 1980.

Nesse período, identificamos apenas uma publicação alinhada com a geografia qualitativa: "O processo de urbanização no continente africano", escrito por Iná Elias de Castro, Naria Helena Lacorte e Nelza Araújo também em 1976. 


\section{CAPÍTULO 4 - AGB E A LUTA PELA REFORMA URBANA NO PERÍODO DO CONGRESSO CONSTITUINTE}

$\mathrm{Na}$ década de 1980 o debate sobre a reforma urbana voltou à tona com muitas mudanças, já que o avanço do processo de urbanização do país, o crescimento das grandes cidades e o acúmulo de lutas no espaço urbano (e periférico) mudaram substancialmente as propostas iniciais. Era o momento de redemocratização do país e de elaboração de uma nova Constituição, reunindo diferentes sujeitos para escrever uma emenda popular pela reforma urbana.

As lutas nesse período vão ser um reflexo de uma cidade ainda mais submetida à acumulação do capital, onde a classe trabalhadora é ainda mais penalizada, vivendo em áreas periféricas cada vez mais afastadas e desprovidas das condições mínimas de dignidade. Assim, as pautas da reforma urbana vão adquirir novos contornos e novos sujeitos de luta serão responsáveis pelas suas articulações, num contexto político que vai permitir uma maior organização dos movimentos sociais. Apesar da maior liberdade decorrente da democratização política, a luta pela reforma urbana sofrerá inúmeros enfrentamentos da parte dos setores econômicos da população que tentarão, sempre que possível, bloquear ou tirar proveito dessas lutas.

As dificuldades e as condições de vida no urbano são fundamentais para entender os movimentos que se organizam já na década de 70, tanto nos anos mais repressivos e "engrandecidos" do regime militar pelo aparente sucesso econômico, como nos anos em que foi mais questionado e se passou a prometer uma abertura lenta, gradual e segura ${ }^{36}$. O urbano e a relação das centralidades com as periferias são pano de fundo para entendermos a revolta pelos transportes, a falta de creches nas periferias, o custo de vida da população atingida pelos baixos salários, a formação de um partido que representava a classe trabalhadora etc.

Todas essas lutas são a base para o que ficou conhecido como a "luta pela reforma urbana”. Afinal, não é possível falar em fazer valer o direito de moradia da população ou de limitar o direito absoluto da propriedade privada sem considerar as experiências dos sujeitos nas periferias das grandes cidades, tanto as conquistas como as dificuldades que explicam as dinâmicas políticas e econômicas atuais do país. Nas palavras de Ana Clara

\footnotetext{
${ }^{36}$ Discurso de Ernesto Geisel durante seu governo (1974-1979).
} 
Torres Ribeiro (1993, p. 116), a luta pela reforma urbana na década de 1980 não está “independentizada de seus vínculos com outros processos de organização social e política que o antecederam e o alimentaram".

Em meio ao processo de urbanização do país e de crescimento das grandes cidades e de suas periferias, os geógrafos estavam inseridos nos mais variados campos da sociedade, como as instituições de planejamento; os movimentos sociais e estudantis, como relataram os professores entrevistados para essa pesquisa ${ }^{37}$; e nas universidades fazendo pesquisas sobre urbanização e a situação nas periferias das metrópoles brasileiras, como podemos perceber pela bibliografia utilizada nessa pesquisa.

Pensamos que as discussões que aconteciam sobre o urbano dentro dos escritórios e instituições como o IBGE, muitas vezes lideradas por geógrafos, têm importância inegável para as políticas públicas, porque a visão territorial e regional permite leituras, análises e estratégicas únicas. No entanto, a realidade e as reivindicações da classe trabalhadora nas ruas, nas fábricas e nas periferias são imprescindíveis para uma geografia urbana que seja comprometida com o social.

É possível fazer uma aproximação entre as duas leituras do espaço urbano? E no campo da política, é possível? Como construímos uma ideia de planejamento mais ampla, ou nas palavras de Arlete Moyses (2013), um planejamento alternativo? Essas perguntas não possuem uma resposta pronta para essa pesquisa. Sabemos que algumas discussões feitas nos órgãos de planejamento tocaram em alguns pontos do debate pela reforma urbana que existia até então, como foi o caso das regiões metropolitanas ${ }^{38}$, apesar de não ser um consenso entre os planejadores da época. Um ponto de partida que nos parece fundamental é o que coloca Rodrigues (1993), de que o ideário da reforma urbana não nega os mecanismos de planejamento. Considera, no entanto, que estes devem ser vistos como gestão e articulação política e não apenas como uma solução técnica de urbanismo. Dessa maneira, o planejamento não pode ser entendido como um modelo de ordenamento racional do território, onde as contradições e conflitos são vistos como desvios do modelo,

\footnotetext{
${ }^{37}$ Por exemplo, Douglas Santos militava no MEP - Movimento pela Emancipação do Proletariado, e junto com Diamantino Pereira, militava nos movimentos estudantis.

${ }^{38}$ Outra possibilidade de intersecção que não teremos espaço nessa pesquisa para aprofundar é a elaboração do projeto de lei de desenvolvimento urbano, que tem uma primeira versão na década de 1970 com a participação de geógrafos, como relatou Maria Adélia de Souza em entrevista. Esse projeto e outros que o substituiriam na década de 1980 foram as "sementes" para o Estatuto da Cidade, conquista importante na luta pela reforma urbana em 2003.
} 
mas devem ser compreendidos na dinâmica política da produção e do consumo da cidade (RODRIGUES, 1993).

Neste capítulo analisaremos a inserção dos geógrafos na luta pela reforma urbana através da Associação dos Geógrafos Brasileiros, entidade que no final da década de 1970 assume a postura de que a ciência não é e não pode ser desinteressada das necessidades da classe trabalhadora e encontra na geografia crítica um instrumento de análise da realidade. Essa inserção ocorre nas iminências do Congresso Constituinte ocorrido no dia primeiro de fevereiro de 1987.

No final da década de 1980 a geografia crítica já havia sido mais amadurecida e debatida entre os geógrafos da AGB e nas universidades, inclusive a geografia urbana, refletindo também a realidade vivida nas cidades e metrópoles do Brasil. A AGB, depois de ter passado por uma trajetória de muitas transformações e de redefinições de caráter, sobretudo após o Movimento de 78, também viu nesse período uma possibilidade de atuar em apoio as lutas sociais, tanto no campo como na cidade.

Assim, a AGB estava engajada em temas tão diversos quanto a Geografia possibilitava. Em 1988, por exemplo, a AGB de São Paulo levou o ambientalista e sindicalista Chico Mendes para uma palestra na USP, o que resultou na edição número 7 de 1990 da revista Terra Livre, a revista da AGB Nacional. Nessa edição, são publicados artigos sobre questões ambientais e da luta dos seringueiros na Amazônia, refletindo as discussões e os encontros que tinham sido feitos sobre o tema na época.

Nesse mesmo ano ocorreu em Maceió, no estado de Alagoas, o VII Encontro Nacional de Geógrafos (foto 5).

Durante esse evento, os geógrafos também se reuniram em frente à sede do Governo de Alagoas, junto com outras entidades como a CUT (foto 6) para uma manifestação. Entre as pautas de protesto estavam à ineficiência política no combate às enchentes no estado e a falta de verbas para a habitação, em um contexto de aprofundamento das políticas neoliberais. 


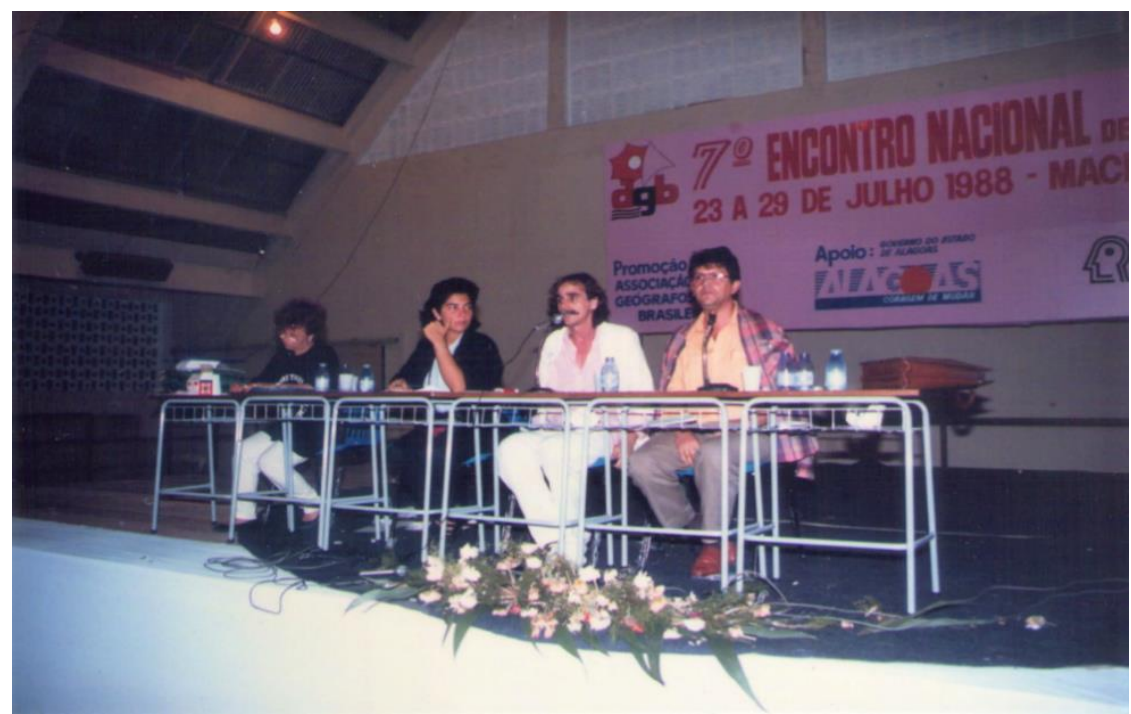

Foto 5 - Mesa do VII ENG, em Maceió, 1988. Da direita para a esquerda: José Borzacchiello da Silva (presidente da AGB); Carlos W. Porto-Gonçalves (vice-presidente da AGB); Vanda Claudino (segunda secretária da AGB); Iracy Palheta (primeira secretária da AGB). Fonte: Projeto Memória da Geografia.

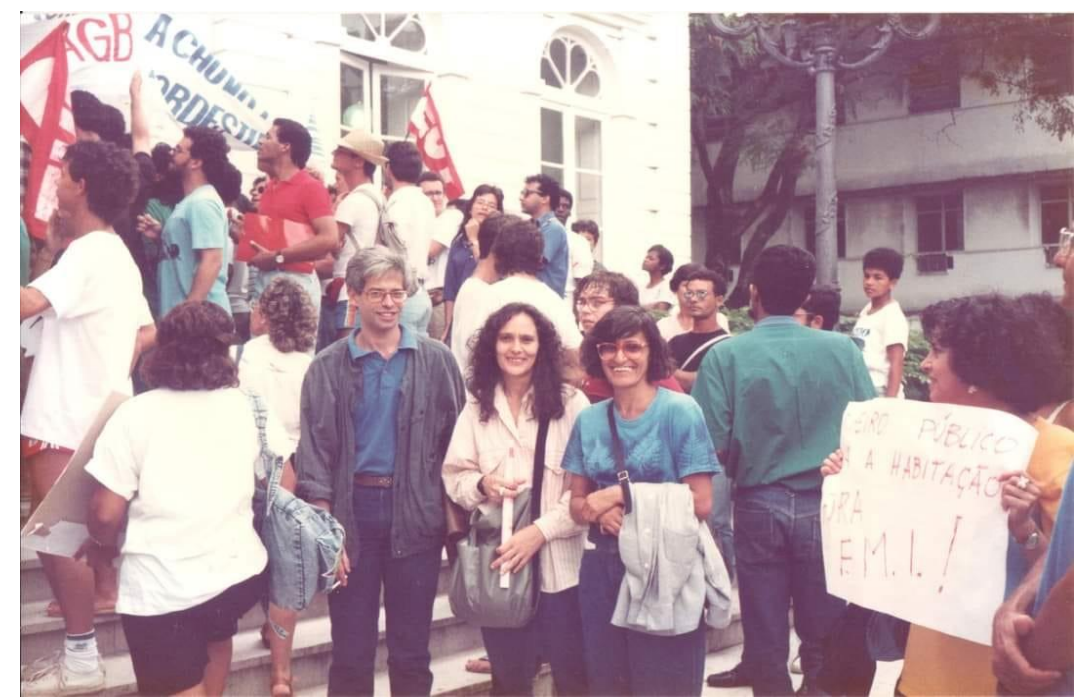

Foto 6 - Geógrafos na manifestação em Alagoas. Da esquerda para a direita: Jean Bitoun, Ana Fani Carlos e Arlete Moysés Rodrigues. Fonte: Projeto Memória da Geografia

A entidade participou da construção de emendas populares para a Constituição em várias áreas. Sobre esse processo, a geógrafa Arlete Moyses Rodrigues, que entre 1988 e 2000 é eleita presidente da AGB, relata:

[...] em 1988, durante o Congresso Constituinte, a AGB foi uma das entidades que participou ativamente das emendas Populares à Constituição, entre elas a da Educação, a da Reforma Agrária e a da Reforma Urbana, áreas e temas que são objetos de estudos de muitos associados. A Associação contribui, assim, não apenas com a geografia brasileira, mas com a nossa representação na sociedade, com extrema relevância sócio-política. (...). Estes poucos exemplos da ação política empreendida pelos associados da AGB demonstram que algumas 
críticas que afirmam que os geógrafos não têm participação ativa na dimensão política são improcedentes (2004, p. 207).

Durante esse período, a AGB recebeu correspondências de diferentes entidades (quadro 5), algumas tratando especificamente do Congresso Constituinte. Entre estas, estão o convite ao evento realizado pela AGB Fortaleza e a ANPUH do Núcleo Regional do Ceará para debater sobre o Congresso e o convite da Secretaria da Ciência e Tecnologia do governo do Estado de São Paulo para o Encontro sobre Ciência e Tecnologia na etapa da Constituinte. Além dos convites para os eventos de debate, o senador Fernando Henrique Cardoso e o deputado Luís Inácio Lula da Silva também mandaram cópias de mensagens à AGB em função das convergências com as pautas da Constituinte.

Quadro 5 - Documentos da AGB relacionados ao período do Congresso Constituinte

\begin{tabular}{|c|c|c|}
\hline Interlocutores da AGB & Conteúdo & Data \\
\hline CUT & $\begin{array}{l}\text { Panfleto sobre o } 2^{\circ} \text { Congresso } \\
\text { Estadual da CUT }\end{array}$ & Julho de 1986 \\
\hline $\begin{array}{c}\text { AGB Seção Fortaleza e } \\
\text { ANPUH Núcleo R. do Ceará }\end{array}$ & $\begin{array}{l}\text { Convite para o Ciclo de } \\
\text { Debates sobre a Constituinte }\end{array}$ & 1986 \\
\hline $\begin{array}{c}\text { Associação de Proteção ao } \\
\text { Meio Ambiente - } \\
\text { APMA/Cambé }\end{array}$ & $\begin{array}{l}\text { Pedido de apoio à defesa do } \\
\text { Parque Nacional do Iguaçu no } \\
\text { Paraná }\end{array}$ & Julho de 1986 \\
\hline CUT & $\begin{array}{l}\text { Convite para o } 3^{\circ} \text { Congresso } \\
\text { da CUT Regional Grande São } \\
\text { Paulo }\end{array}$ & Dezembro de 1986 \\
\hline $\begin{array}{l}\text { Vereadora do PT autora da } \\
\text { moção de apoio à } \\
\text { reivindicação da profissão } \\
\text { dos geógrafos }\end{array}$ & $\begin{array}{l}\text { Encaminhamento da resposta } \\
\text { de órgãos quantos a questão } \\
\text { do reconhecimento do } \\
\text { geógrafo como profissão, } \\
\text { como Ministério do Trabalho }\end{array}$ & 1986 \\
\hline $\begin{array}{l}\text { Presidente da Câmara } \\
\text { Municipal de São Paulo }\end{array}$ & $\begin{array}{l}\text { Expressão de apoio ao } \\
\text { reconhecimento da profissão } \\
\text { do geógrafo }\end{array}$ & Junho de 1986 \\
\hline $\begin{array}{c}\text { Secretariado aos membros } \\
\text { do Movimento pela Reforma } \\
\text { Urbana do Estado de São } \\
\text { Paulo }\end{array}$ & $\begin{array}{l}\text { Informações sobre a coleta de } \\
\text { assinaturas para apoio popular } \\
\text { e chamado para ato em defesa } \\
\text { da Reforma Urbana }\end{array}$ & Junho de 1986 \\
\hline $\begin{array}{c}\text { Ministério da Habitação, } \\
\text { Urbanismo e Meio } \\
\text { Ambiente }\end{array}$ & $\begin{array}{l}\text { Convite para a III Semana } \\
\text { Nacional de Desenvolvimento } \\
\text { Urbano }\end{array}$ & Novembro de 1987 \\
\hline $\begin{array}{c}\text { Secretaria da Ciência e } \\
\text { Tecnologia do governo do } \\
\text { Estado }\end{array}$ & $\begin{array}{l}\text { Convite para o Encontro sobre } \\
\text { Ciência e Tecnologia na } \\
\text { Constituinte }\end{array}$ & Maio de 1987 \\
\hline $\begin{array}{l}\text { Sindicato de Engenheiros do } \\
\text { Estado de Minas }\end{array}$ & $\begin{array}{l}\text { Carta sobre quatro propostas à } \\
\text { Constituinte - Direitos dos }\end{array}$ & Julho de 1987 \\
\hline
\end{tabular}




\begin{tabular}{|c|c|c|}
\hline & $\begin{array}{l}\text { Trabalhadores, Reforma } \\
\text { Agrária, Ciência e Tecnologia } \\
\text { e Reforma Urbana - e pedido } \\
\text { de assinaturas }\end{array}$ & \\
\hline $\begin{array}{l}\text { Secretaria de Obras e do } \\
\text { Meio Ambiente }\end{array}$ & $\begin{array}{l}\text { Convite para Seminário sobre } \\
\text { Gestão de Recursos Hídricos }\end{array}$ & Setembro de 1986 \\
\hline $\begin{array}{c}\text { Senador Fernando Henrique } \\
\text { Cardoso }\end{array}$ & $\begin{array}{l}\text { Carta de agradecimento aos } \\
\text { que deram apoio ao PMDB e } \\
\text { pedido de apoio no período da } \\
\text { Constituinte }\end{array}$ & Novembro de 1986 \\
\hline $\begin{array}{c}\text { Sociedade Brasileira para o } \\
\text { Progresso da Ciência - } \\
\text { SBPC }\end{array}$ & \begin{tabular}{lccr} 
Convite para & \multicolumn{2}{c}{ Simpósio } \\
Centenário da & Criação & da \\
Comissão & Geográfica & e \\
Geológica & & & \\
\end{tabular} & Maio de 1986 \\
\hline $\begin{array}{l}\text { ANPUH Núcleo de São } \\
\text { Paulo }\end{array}$ & $\begin{array}{l}\text { Circular sobre o VIII Encontro } \\
\text { de História de São Paulo: } \\
\text { História, Cultura e Trabalho }\end{array}$ & Setembro de 1986 \\
\hline UERJ & $\begin{array}{l}\text { Convite para o } 1^{\circ} \text { Congresso } \\
\text { Brasileiro de Saúde Coletiva }\end{array}$ & Setembro de 1986 \\
\hline $\begin{array}{c}\text { Secretaria de Agricultura e } \\
\text { Abastecimento do Estado de } \\
\text { São Paulo - Instituto } \\
\text { Geológico }\end{array}$ & $\begin{array}{l}\text { Convite para participar da } \\
\text { reunião do Conselho } \\
\text { Consultivo Externo do } \\
\text { Instituto Geológico }\end{array}$ & 1986 \\
\hline $\begin{array}{c}\text { Secretariado aos membros } \\
\text { do Movimento pela Reforma } \\
\text { Urbana no Estado de São } \\
\text { Paulo }\end{array}$ & $\begin{array}{l}\text { Convite para ato de defesa das } \\
\text { propostas populares de } \\
\text { emendas ao projeto de } \\
\text { Constituição-Reforma Urbana } \\
\text { e Participação Popular }\end{array}$ & Julho de 1986 \\
\hline SASP & $\begin{array}{l}\text { Convite para posse da nova } \\
\text { Diretoria }\end{array}$ & Março de 1987 \\
\hline CUT & $\begin{array}{l}\text { Convite para o } 4^{\circ} \text { Congresso } \\
\text { da CUT Regional Grande São } \\
\text { Paulo }\end{array}$ & Novembro de 1987 \\
\hline $\begin{array}{l}\text { Gabinete da Liderança do } \\
\text { Partido dos Trabalhadores }\end{array}$ & \begin{tabular}{l}
\multicolumn{3}{|c}{ Discurso do Constituinte Luís } \\
Inácio Lula da Silva no \\
Horário de Liderança na \\
Assembleia \\
Constituinte
\end{tabular} & Agosto de 1987 \\
\hline
\end{tabular}

Fonte: Elaborado pela autora. Fonte: Arquivo da AGB Nacional.

Além destes documentos que tratam de maneira direta da etapa Constituinte, outras correspondências do período mostram um canal de diálogo da AGB com organizações que estavam mobilizadas por diferentes pautas, como é caso da CUT e sindicatos de arquitetura e engenharia; de entidades como a ANPUH e a Sociedade Brasileira para o Progresso para a Ciência $^{39}$; de órgãos do poder público, como o

${ }^{39}$ A AGB esteve filiada à SBPC na década de setenta, entidade de cunho científico. 
Ministério da Habitação, Urbanismo e Meio Ambiente e de vereadores da Câmara Municipal de São Paulo, que estavam emitindo apoio ao reconhecimento da profissão dos geógrafos ${ }^{40}$.

Sobre a relação da AGB com a CUT, Rodrigues relata:

Uma das questões emblemáticas da participação da AGB no movimento da sociedade foi a aprovação, em 1988, na plenária de Maceió da filiação da AGB à Central Única dos Trabalhadores - CUT. A Central Única dos Trabalhadores não poderia aceitar nossa filiação, pois a CUT é uma filial sindical e a AGB congrega estudantes que não são considerados passíveis de estarem representados em um sindicato ou numa central sindical. A participação de representante da CUT em Salvador, em 1990, encerrou uma polêmica interna que ocorreu durante dois anos, ou seja, a ideia de que não havia empenho por parte da Diretoria Executiva Nacional em cumprir uma das deliberações da Assembleia de Maceió. Mas, o mais importante a ressaltar, é que a intenção em filiar-se a uma central sindical, num momento de crescente mobilização social, demonstrava o interesse dos geógrafos em participar do movimento geral da sociedade (2004, p. 9).

Esse momento emblemático citado por Arlete, quando houve a tentativa de alguns membros da AGB de filiarem a entidade à CUT - ideia que não foi adiante em função das características distintas das duas organizações - demonstra, além do interesse dos geógrafos em participar do movimento geral da sociedade, a postura da AGB de reconhecer que a Geografia e os geógrafos e geógrafas deveriam contribuir com a classe trabalhadora.

\subsection{A emenda popular pela reforma urbana e a Constituição}

Os geógrafos da AGB também se dispuseram a apoiar os movimentos sociais urbanos. Nesse momento, a luta pela reforma urbana é retomada, mas dessa vez expressando um urbano diferente daquele da década de 1960, quando aconteceu o Seminário de Habitação e Reforma Urbana. Da reunião de entidades, ONGs e movimentos sociais urbanos que desejavam colocar a Constituição de 1988 a favor dos mais pobres no espaço urbano, surgiu o Movimento Nacional pela Reforma Urbana MNRU, que enviou uma proposta de uma emenda popular pela reforma urbana ao Congresso Constituinte.

\footnotetext{
${ }^{40}$ A AGB foi o principal sujeito de luta na conquista do reconhecimento da profissão de geógrafo, em 1979.
} 
A AGB integrou o MNRU, como podemos perceber nos documentos abaixo, que também estão presentes no quadro 3. Em um destes documentos (figura 5), em que é feito a divulgação de um ato na Faculdade de Direito do Largo São Francisco em defesa das propostas em prol da reforma urbana para a Constituição, estão listadas todas as entidades que compõem este movimento no estado de São Paulo, sendo a AGB incluída nessa relação.

O segundo documento direcionado aos mobilizados em torno do Movimento Nacional pela Reforma Urbana trata da coleta de assinaturas para a iniciativa popular e da importância dessas ações frente às pressões dos conservadores; e do anúncio de um Encontro Nacional pela Reforma Urbana (figura 6).

Não podemos esquecer que a emenda popular pela reforma urbana foi originária das experiências de lutas urbanas que emergiram nas cidades nas décadas anteriores, como os movimentos de favelas e movimentos de comunidades de bairros periféricos que através de suas organizações exigiram do poder público seus direitos aos serviços básicos, como saneamento, iluminação e saúde. Essas ações coletivas também contestaram o direito absoluto de propriedade por meio das ocupações de terras que estavam sem nenhuma utilização social na defesa da moradia para a população de baixa renda. Dessa maneira, tornou-se fundamental que esses direitos que estavam sendo conquistados nas ações políticas dos sujeitos marginalizados fossem protegidos pela Constituição (SAULE JÚNIOR, 1993).

A emenda popular tinha como objetivo criar um capítulo específico na Constituição sobre a questão urbana, em um cenário onde $70 \%$ da população vivia nas cidades. Assim, era baseada em quatro pontos básicos: garantir os direitos urbanos; limitar o direito de propriedade e controlar o direito de construir; garantir que a produção de moradia, dos transportes e dos serviços públicos não fosse objeto de lucro, mas uma responsabilidade do Estado; e garantir uma gestão democrática da cidade (BONDUKI, 2018). 
Figura 5 - Divulgação de ato do MNRU em defesa de emendas populares no período da Constituinte

EXMO SR.

O Movimento pela Reforma urbana e o Plenārio Pró Particinação Popular na Constituinte-regional de São Paulo,farā realizar um ato de defesa das propostas populares de emendas ao projeto de Constituição-Reforma Urbana e Participação Popular.

O ato contará com apresença de urbanistas, parlamentares e lideranças populares do Estado de São Paulo,e terá lugar na Sala do Estudante da Faculdade de Direito do Largo de são Francisco, no dia 13 de julho(segunda feira), às 20:00 hs.

Certos de que V.Excia. se sensibilizará para a importancia de seu comparecimento ao evento, agradecemos.

Comnõem o MOVIMENTO PELA REFORMA URBANA no Estado de São paulo, as seguintes entidades:

COMISSÃO ARTUIDIOCESANA DE DIREITOS HUMANOS ARTICULAC ÃO NACIONAL DO SOLO URBANO

ARTCRAC ̃̃O DAS ASSOCIACÕES DE MUTUẼRIOS DO ESTADO DE S.PAULO

SINDICATO DE ARQUITETOS DO ESTADO DE S, PAULO

SINDICATO DE AR?UITETIROS DO ESTADO DE S.PAULO

ASSOCIAC.ÃO DOS GEOCRAFOS BRASILEIROS-SP

MOVIMENTO UNITICADO DE FAVELAS -MUF

MOVIMENTO DOS SEI TERRA DA ZONA LESTE

MOVIMENTO DOS SEM CASA

MOVIMENTO DOS INOUILINOS INTRANQUILOS

MOU.

MOVIMENTO TERRA PROMETIDA DA ZONA NORTE DE SÃO PAULO

MOVIMENTO TERRA PROMETIDA DA TONA-ADM

ASSOCIACÃO EM DETESA DA -IORARO ACADEMICO XI DE AGOSTO

NÚCLEO DE HABITAC.AO DO CENTA TAU.

LABORATORIO DE HABITAC. AO DA

ASSEMBLEIA DO POVO DE CAS CLANDESTINOS DA ZONA SUL DE SÃO PAULO MOVIMENTO DE LOTEA.MENTOS CLANDESTINOS DA ZONA SUDESTE-S, PAULO MOVIMENTO DE LOTEAMENTOS CLANDES CANARIM-GUARULHOS

CENTRO DE DEFESA DA TERRA PAJLO CANARINONTITUINTE-GUARULHOS PLENARIA PRO PARTICIPAC.AO DOTULARAOCETUBA

MOYIMENTO DOS SEM. TERRA DE

COMISSÃO DA TERRA DE MAUA

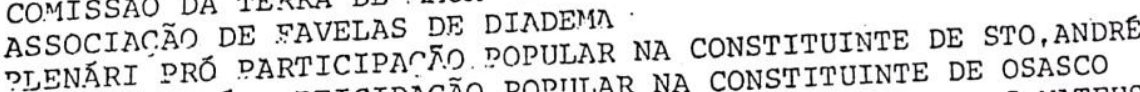
PLENÁRIO PRÓ PARTICIPAÇÃO POPJLAR NA CONSTITUINTE DE S.MATEUS PLENÁRIO DRర DARTICIPACAO POPULAR

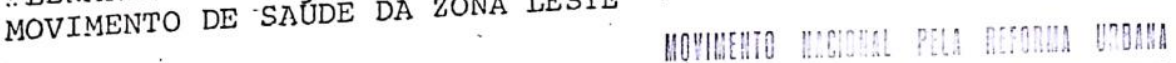

Fonte: Arquivo da AGB Nacional. 
Figura 6 - Divulgação do MNRU sobre campanha de coleta de assinaturas e mobilização no período da Constituinte

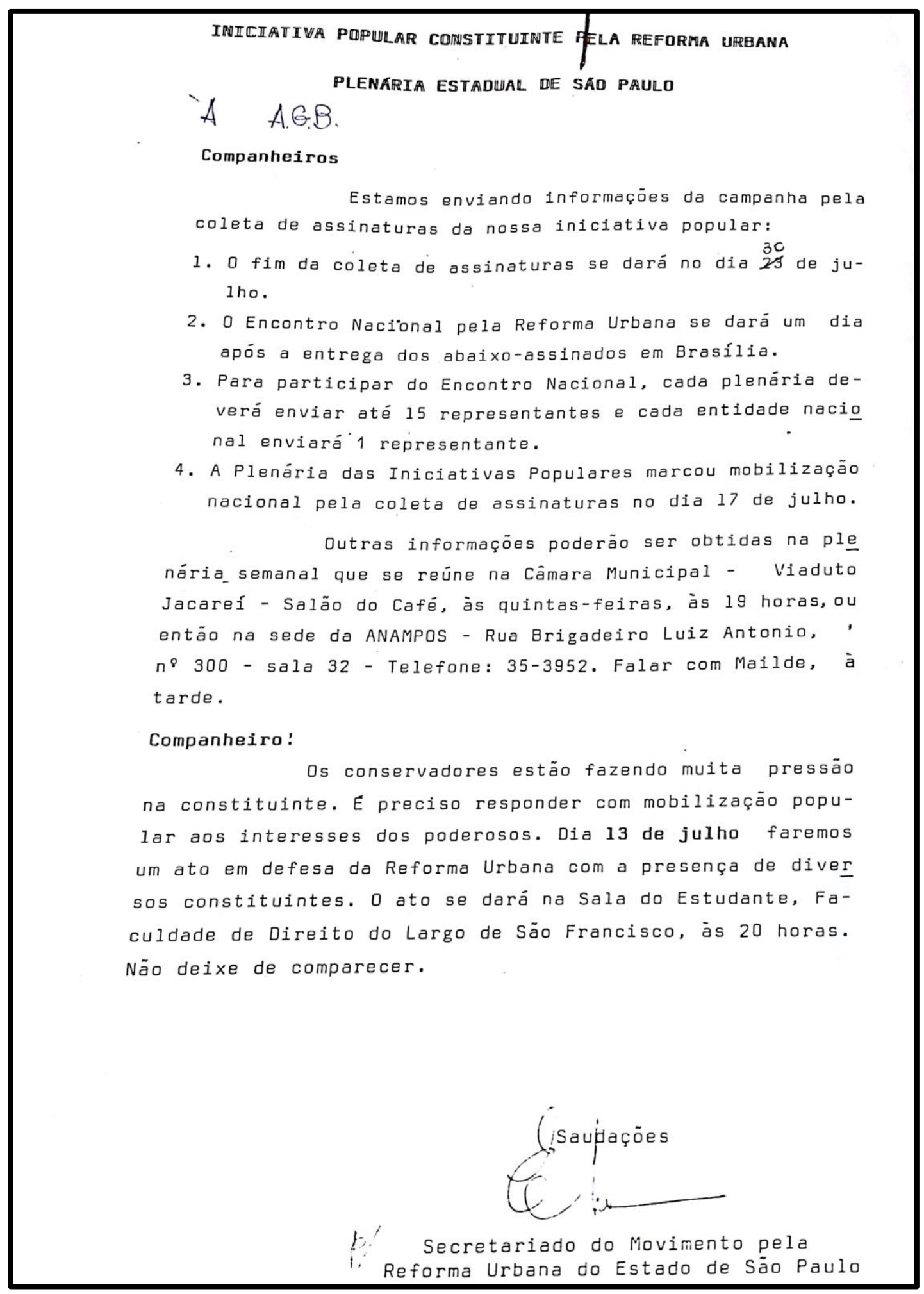

Fonte: Arquivo Nacional da AGB.

Nesse contexto em que há uma passagem de processos que organizam diretamente a sociedade para o âmbito das conquistas jurídicas formais (RIBEIRO, 1993), o capítulo da Política Urbana na nova Constituição ficou restrito a apenas dois artigos, tendo a 
emenda popular um papel fundamental na inclusão da função social da propriedade e da cidade. O capítulo também definiu o Plano Diretor como instrumento básico da política urbana, tornando-o obrigatório para municípios com mais de 20.000 habitantes (FERREIRA, 2012; SANTO AMORE, 2013).

Como já mencionado anteriormente, o planejamento, seja urbano ou territorial, tem limitações sérias e, muitas vezes, a forma, ou a parte técnica, se sobrepõe ao conteúdo contido por trás das leis, ou seja, à própria realidade. Nesse sentido, mesmo tendo sido o resultado de uma ampla luta, a obrigação do Plano Diretor para os municípios com população superior a 20.000 pode ser entendida como uma espécie de "aprisionamento" da função social da propriedade, que deveria valer incondicionalmente no controle da propriedade privada e não ficar dependendo da aplicação de cada município (RODRIGUES, 2013). Nesse sentido, precisamos nos atentar às diferenças históricas entre vida social e crença nas leis, bem como entre a população e os raciocínios e códigos técnicos do planejamento (RIBEIRO, 1993).

No entanto, de acordo com José Borzachiello da Silva:

Hoje as cidades mostram-se mais democráticas e permitem a exposição de algumas mazelas. Habitação precária, serviço de transporte deficiente, desigual distribuição de renda, entre outras. Os pobres também mudaram: continuam pobres conforme a lógica da sociedade capitalista, mas adquiriram noções de direitos tanto no mundo do trabalho quanto no que se relaciona à cidade enquanto local de moradia e realizações (2016, p. 173).

As mobilizações que já aconteciam nas periferias das grandes cidades e que depois se aglutinaram em torno da Constituição para que alguns direitos pudessem ser permanentes trouxeram muitos aprendizados para a população mais pobre. A AGB também saiu mais fortalecida, pois dessa atuação no período da elaboração da Constituição e das mobilizações que são realizadas, é criada a Comissão de Assuntos Urbanos da AGB. Assim, as articulações que se deram na época não foram apenas entre as diferentes entidades, mas dentro da própria AGB, que viu a necessidade de discutir as questões urbanas com mais profundidade.

\subsection{A Comissão de Assuntos Urbanos da AGB}

Desde 1989 a AGB passou a ter uma Comissão Nacional de Urbana, o que representou uma forma de ação mais direta nos assuntos ligados à reforma urbana. Essa Comissão teve origem no I Simpósio Nacional de Geografia Urbana - SIMPURB, 
realizado em São Paulo no mesmo ano. Assim, muitas correspondências encontradas no arquivo da AGB foram endereçadas a essa Comissão. Arlete Moyses relata sobre essa Comissão, que começou a ser organizada um ano antes:

[...] a gente montou em 1988 um Grupo de Trabalho de Urbana. Então tinha a Comissão de Urbana da AGB. É um momento histórico da sociedade. Tinha muita gente envolvida na coleta de assinaturas, em debater as questões, e em 1988 se formou pela primeira vez que eu saiba na história da AGB a Comissão de Urbana da AGB, que aí faziam parte - eu era presidente da AGB de 1988 a 1990 - o Roberto Lobato, Jan Bitoun, Ana Fani, Odete Seabra, nomes que você conhece. Então a gente formou uma Comissão de Urbana. Então veja, tinha uma dinâmica de importância, o mundo mudou, a população urbana também aumentou, e aí também os problemas aumentaram. Não é que não tivesse antes, mas é que a dimensão e a escala mudaram. Então tem essa dinâmica de formar ao mesmo tempo a Comissão de Urbana. Da onde saiu? Do Simpósio de Geografia Urbana. Não tem nada desarticulado (Arlete Moyses, entrevista a Larissa Araujo, fevereiro de 2017).

Nas palavras da professora, nada estava desarticulado e todas as construções eram resultado de um esforço de luta e de mobilizações. Mesmo com as conquistas na Constituição, a vida nas cidades e sobretudo nas periferias exigia que os movimentos continuassem se articulando a partir daquilo que já havia sido feito e buscando novas saídas. A AGB acompanhava esse processo e a formação da Comissão de Assuntos Urbanos era fundamental.

A Comissão de Assuntos Urbanos, portanto criada conjuntamente ao $1^{\circ}$ Simpósio Nacional de Geografia Urbana, organizou, em 1993, o $3^{\circ}$ Simpósio Nacional de Geografia Urbana $^{41}$, realizado no Rio de Janeiro. Nesta gestão de 1992 a 1994 da AGB, o Coordenador da Comissão era o geógrafo mineiro Willian Rosa (foto 7).

O Simpósio no Rio de Janeiro foi realizado na UFRJ e teve patrocínio do Departamento de Geografia da UFRJ, do IBGE e do CNPq. Destaca-se esse evento porque entre as mesas de debates, a mesa 5 discutiu o tema da reforma urbana e foi intitulada "Crise Urbana e Reforma Urbana" (AGB, 1993).

\footnotetext{
${ }^{41}$ O $2^{\circ}$ Simpósio Nacional de Geografia Urbana aconteceu em 1991, na cidade de Rio Claro/SP. Na gestão de 1990 a 1992, o Coordenador da Comissão de Assuntos Urbanos era José Borzachiello da Silva.
} 


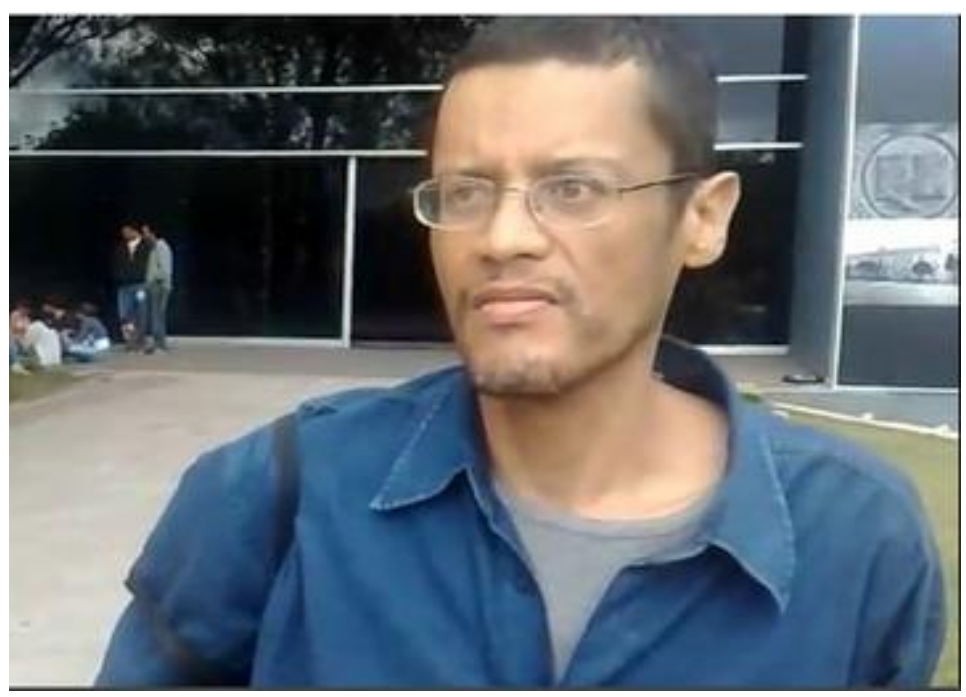

Foto 7: Geógrafo mineiro William Rosa. Fonte: Site da Universidade Federal de Minas Gerais.

Nesta mesa participaram a geógrafa Arlete Moyses Rodrigues com a apresentação "Desenvolvimento ou reforma urbana: concepções e contradições"; a socióloga Ana Clara Torres Ribeiro que apresentou "Reforma Urbana nos limites da modernização", Nelson Saule Júnior da área do Direito com "Direito e Reforma Urbana"; o geógrafo Marcelo Lopes de Souza, com “Miseropolização e 'clima de guerra civil': sobre o agravamento e as condições de superação da questão urbana na metrópole do Rio de Janeiro" e o engenheiro Franklin Coelho com a apresentação "Reforma urbana e territorialidades" (AGB, 1993).

Nesse momento, estava também se formando o Fórum Nacional de Reforma Urbana, que se articulou a partir do Movimento Nacional de Reforma Urbana, e a AGB se integraria a este Fórum.

\subsection{O Fórum Nacional de Reforma Urbana}

Apesar das limitações do capítulo da Política Urbana na Constituição, que seriam apenas em parte resolvidas com a aprovação do Estatuto da Cidade em 2001, a mobilização dos movimentos e técnicos foi importante para o surgimento do Fórum Nacional de Reforma Urbana. Àqueles que compunham o Movimento Nacional pela Reforma Urbana no período da Constituinte, foram se somando outras entidades. Atualmente, o Fórum é formado por quatro movimentos por moradia, doze ONGs e setes entidades profissionais, entre estas a AGB (SANTO AMORE, 2013).

O FNRU não tem estatuto ou características institucionais. Rege-se por princípios na defesa dos direitos à moradia e à cidade, aos transportes públicos de qualidade, ao 
meio ambiente saudável e ao saneamento ambiental. Há também fóruns regionais, ou mesmo estaduais em quase todas as regiões do Brasil (RODRIGUES, 2007; RODRIGUES, 2009). Em relação à participação da AGB no Fórum, Arlete Rodrigues relata:

\begin{abstract}
A AGB por meio de várias seções locais e da Nacional participa do Fórum desde os seus primórdios, com o objetivo de integrar e participar da luta pelo Direito à Cidade ou da Cidade como Direito: debates em todas as instâncias nacionais e internacionais, formulações de textos, documentos, conferências municipais, estaduais e nacionais, de eventos organizados por movimentos sociais $(2009$, p. 1$)$
\end{abstract}

Entre os documentos pesquisados na AGB, encontramos registros que reafirmam essa participação relatada por Arlete nas atividades do Fórum por Reforma Urbana, tanto no nível nacional como no do Estado de São Paulo. Esses registros não se restringem ao momento da fundação do Fórum, mas mostram quase uma década de articulações e discussões após 1988. Todas essas discussões foram norteadas pelos Encontros Nacionais do Fórum e, no documento [inacabado] abaixo (figura 7), a agebeana Arlete Moyses busca sistematizar todos os temas discutidos durante os quatro primeiros Encontros.

A AGB, além de ser entidade participante desde a fundação em 1988, esteve na Coordenação do Fórum Nacional da Reforma Urbana a partir de 1991 até os dias de hoje, o que mostra o engajamento da entidade, apesar dessa participação ficar muitas vezes limitadas a poucas pessoas, como analisaremos a seguir.

O primeiro Encontro Nacional pela Reforma Urbana foi um momento de avaliação feita pelo Fórum a partir da aprovação do Capítulo da Política Urbana na Constituição, quando se pode analisar aquilo que havia sido proposto na emenda popular e aquilo que de fato foi aprovado. A partir dos próximos Encontros, as entidades que compõem o Fórum começaram a discutir as outras lutas que surgiram a partir da Constituição, como os Planos Diretores; a Conferência Eco - 92 e o Fórum Internacional de Reforma Urbana; a Conferência Habitat II e a luta contra o Projeto Cingapura; o Estatuto da Cidade, o Fundo Nacional de Moradia Popular etc.

Não é objetivo tratar de todos esses temas e do envolvimento da AGB nessas discussões que foram construídas depois do Congresso Constituinte. No entanto, em nossa pesquisa, muitos documentos sobre essa trajetória da AGB foram resgatados e caberiam novas pesquisas a partir desse esforço inicial. 
Figura 7 - Esboço escrito por Arlete Moyses sobre os quatro primeiros Encontros do FNRU

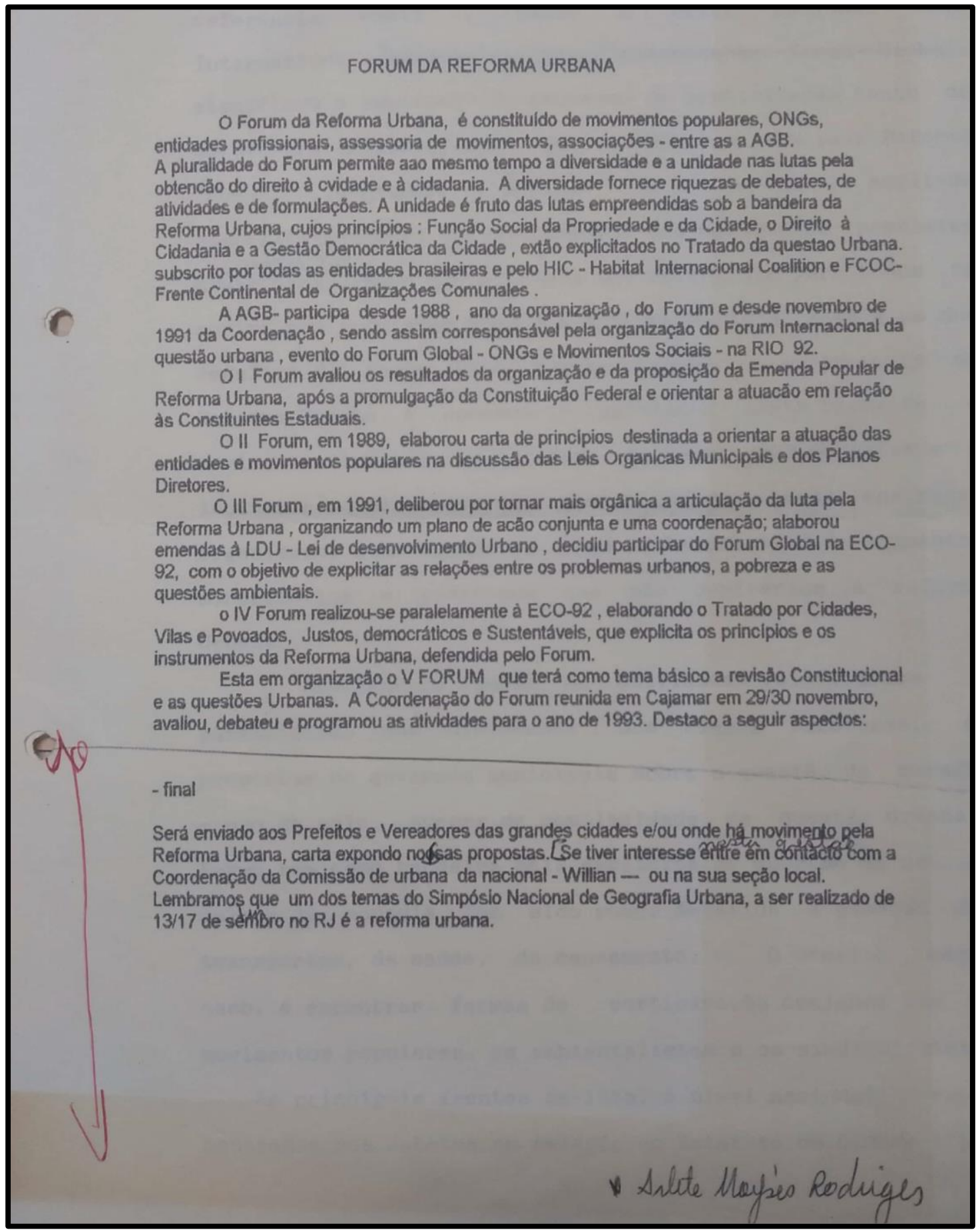

Fonte: Arquivo da AGB Nacional.

No final do esboço, a geógrafa Arlete Moyses alertou para o fato que o tema da reforma urbana seria assunto do $3^{\circ}$ Simpósio Nacional de Geografia Urbana, que aconteceria no Rio de Janeiro no ano de 1993. Assim, fica evidente a importância desse Simpósio para a organização dos geógrafos na luta pela reforma urbana, já que o primeiro 
Simpósio havia sido o ponto inicial para a criação da Comissão de Urbana da AGB e terceiro seria um desdobramento das atividades dessa Comissão.

O geógrafo William Rosa, da Seção Local de Belo Horizonte - BH, também escreveu sobre a participação da AGB no Fórum Nacional de Reforma Urbana e na Comissão de Assuntos Urbanos da AGB, da qual foi também coordenador. Esse importante sujeito da entidade tristemente faleceu em 2013 aos 45 anos de idade. Segundo ele, a AGB de BH, que foi criada em 1988, já havia se envolvido em um Fórum PróParticipação Popular no Plano Diretor da cidade no começo da década de 1990. Para uma escala mais ampla:

Nossa participação nos Fóruns Nacionais da Reforma Urbana- alguns deles ocorridos em Belo Horizonte - implicou na defesa de nosso nome, por parte da Seção Local, para Coordenador da Comissão Nacional de Assuntos Urbanos e Regionais da AGB na gestão 1992-1994 (ALVES, 2004, p. 233).

William afirma que a "questão urbana" compareceu irregularmente na pauta da AGB-BH. Para ele, foi fundindo com a questão ambiental e/ou a "questão educacional" que as atividades da entidade deram importantes contribuições à sociedade (ALVES, 2004). Discutiremos mais sobre essas "irregularidades" da AGB no tópico a seguir, pensando nas contradições que permearam e permeiam o caminho da entidade.

\subsection{As cidades e o urbano no boletim da AGB}

Na primeira metade dos anos 1980, como nos apontou Abreu, as publicações em geografia urbana crítica ainda eram raras, já que os geógrafos estavam às voltas com o próprio processo de restruturação teórico-metodológica da ciência. No entanto, percebese que, a partir de meados da década de 1980 há um esforço da comissão organizadora do BPG em selecionar como temas para as novas edições as lutas que estavam ocorrendo tanto no campo como na cidade. Chama a atenção a edição de número 64 do ano de 1986, que tem todos os seus artigos voltados para o tema da moradia nas cidades brasileiras.

As publicações do BCG vão até o ano de 1982, o que ajuda a explicar a pequena quantidade de artigos que sinalizam em direção a uma geografia crítica. Outra possível explicação, como mencionamos, está no maior envolvimento da Geografia do Rio de Janeiro com a Geografia Quantitativa, reforçando o trânsito e a influência entre os 
geógrafos da Seção Carioca da AGB, do IBGE e da Universidade Federal do Rio de Janeiro, relação que não percebemos nas publicações da AGB - SP.

Abaixo procuramos sinalizar no quadro as publicações da geografia urbana crítica tanto no BPG (quadro 6), como no BPC (quadro 7) a partir da década de 1980.

Quadro 6 - Publicações sobre cidade e o urbano no BPG (Década de 1980)

Legenda:

Geografia Crítica

\begin{tabular}{|l|l|l|l|}
\hline \multicolumn{1}{|c|}{ Título do artigo } & \multicolumn{1}{|c|}{ Autor (a) } & \multicolumn{1}{|c|}{$\mathbf{N}^{\mathbf{0}}$} & \multicolumn{1}{c|}{ Ano } \\
\hline Uma vila do litoral paulista - Icapara & Nice Lecoq Muller & 1 & 1949 \\
\hline Oxford, cidade de ontem e de hoje & Nice Lecoq Muller & 2 & 1949 \\
\hline A “vila" de Itanhaém & José Ribeiro de Araujo Filho & 6 & 1950 \\
\hline A cidade de Olímpia & E. Goulart Pereira de Araujo & 9 & 1951 \\
\hline $\begin{array}{l}\text { As paisagens humanizadas da ilha de } \\
\text { São Sebastião }\end{array}$ & Ary França & & \\
\hline $\begin{array}{l}\text { Aspectos geográficos e problemas da } \\
\text { região de Corumbataí }\end{array}$ & Pasquale Petrone & 11 & 1952 \\
\hline $\begin{array}{l}\text { As indústrias paulistanas e os fatores } \\
\text { da expansão }\end{array}$ & Pasquale Petrone & 14 & 1953 \\
\hline $\begin{array}{l}\text { Aspectos geográficos do crescimento } \\
\text { da cidade de São Paulo }\end{array}$ & Pierre Monbeig & 16 & 1954 \\
\hline $\begin{array}{l}\text { Ensaio de geografia urbana de New } \\
\text { York }\end{array}$ & Pierre Deffontaines & 17 & 1954 \\
\hline $\begin{array}{l}\text { Contribuição à geografia urbana de } \\
\text { Nagoia }\end{array}$ & Kanji Kagami & 18 & 1954 \\
\hline $\begin{array}{l}\text { Porto Alegre, metrópole do Brasil } \\
\text { meridional }\end{array}$ & Jean Roche & 19 & 1955 \\
\hline Crato, "capital" da região do Cariri & Pasquale Petrone & 20 & 1955 \\
\hline $\begin{array}{l}\text { Contribuição ao estudo do norte do } \\
\text { Paraná }\end{array}$ & Nice Lecoq Muller & 22 & 1956 \\
\hline O homem paulista & Pasquale Petrone & 1956 \\
\hline $\begin{array}{l}\text { Ponta Grossa, capital regional do } \\
\text { oeste do Paraná }\end{array}$ & Elina O. Santos & 1956 \\
\hline Embriões de Cidades Brasileiras & Aroldo de Azevedo & 1958 \\
\hline $\begin{array}{l}\text { Rua da Consolação, uma das artérias } \\
\text { da capital paulista }\end{array}$ & José Domingos Tirico & 29 & 1959 \\
\hline $\begin{array}{l}\text { Aix-Em-Provence, uma cidade do } \\
\text { mediterrâneo francês }\end{array}$ & Antônio Rocha Penteado & 31 \\
\hline A circulação urbana & Michel Tabuteau & 1958 \\
\hline
\end{tabular}




\begin{tabular}{|c|c|c|c|}
\hline $\begin{array}{l}\text { Contribuição ao estudo dos centros de } \\
\text { cidades: o exemplo da cidade de } \\
\text { Salvador }\end{array}$ & Milton Santos & 32 & 1959 \\
\hline $\begin{array}{l}\text { Características e tendências } \\
\text { principais das migrações internas } \\
\text { no Brasil, nas suas relações com a } \\
\text { urbanização e a industrialização }\end{array}$ & José Francisco de Camargo & 33 & 1959 \\
\hline $\begin{array}{l}\text { Brazzaville: alguns aspectos de } \\
\text { uma cidade da África francesa }\end{array}$ & Pierre Vennetier & 34 & 1960 \\
\hline Sousas, subúrbios de Campinas & José Domingos Tirico & 35 & 1960 \\
\hline $\begin{array}{l}\text { Aspectos dos quadros urbanos da } \\
\text { Baixada Do Ribeira, SP }\end{array}$ & Pasquale Petrone & 38 & 1961 \\
\hline $\begin{array}{l}\text { O sítio urbano de Porto Alegre: } \\
\text { estudo geográfico }\end{array}$ & Aziz Nacib Ab'Saber & 42 & 1965 \\
\hline $\begin{array}{l}\text { Experiências de colonização em } \\
\text { uma área tropical: A Baixada da } \\
\text { Ribeira }\end{array}$ & Pasquale Petrone & 42 & 1965 \\
\hline $\begin{array}{l}\text { Contribuição ao estudo da indústria } \\
\text { têxtil de Americana (Estado De } \\
\text { São Paulo) }\end{array}$ & Helmut Troppmair & 43 & 1966 \\
\hline $\begin{array}{l}\text { Paraná: o quadro geográfico, } \\
\text { histórico e econômico do processo } \\
\text { de urbanização }\end{array}$ & Maria Adélia A. de Souza & 46 & 1971 \\
\hline $\begin{array}{l}\text { Os núcleos de colonização oficial } \\
\text { implantados no planalto paulistano } \\
\text { em fins do século XIX }\end{array}$ & Juerge Richard Langenbuch & 46 & 1971 \\
\hline O bairro industrial do Jaguaré, SP & $\begin{array}{l}\text { Léa Goldenstein, Rosa Ester } \\
\text { Rossini }\end{array}$ & 47 & 1972 \\
\hline $\begin{array}{l}\text { Características do espaço } \\
\text { econômico industrial }\end{array}$ & Armando Corrêa da Silva & 48 & 1973 \\
\hline $\begin{array}{l}\text { Os centros industriais do Estado } \\
\text { São Paulo }\end{array}$ & Beatriz Maria Soares Pontes & 49 & 1974 \\
\hline $\begin{array}{l}\text { O processo de industrialização em } \\
\text { São Paulo }\end{array}$ & Armen Mamigonian & 50 & 1976 \\
\hline $\begin{array}{l}\text { Regionalização: tema geográfico e } \\
\text { político - o caso paulista }\end{array}$ & Maria Adélia de Souza & 50 & 1976 \\
\hline $\begin{array}{l}\text { Desenvolvimento econômico e } \\
\text { urbanização em países } \\
\text { subdesenvolvidos: os dois sistemas } \\
\text { de fluxo da economia urbana e suas } \\
\text { implicações espaciais }\end{array}$ & Milton Santos & 53 & 1977 \\
\hline $\begin{array}{l}\text { Desenvolvimento de comunidade } \\
\text { no processo de urbanização: notas } \\
\text { para uma crítica das teorias } \\
\text { sociológicas do planejamento }\end{array}$ & Henrique Rattner & 54 & 1977 \\
\hline
\end{tabular}




\begin{tabular}{|c|c|c|c|}
\hline $\begin{array}{l}\text { A planificação do desenvolvimento } \\
\text { de regiões atrasadas }\end{array}$ & Henrique Rattner & 56 & 1979 \\
\hline Geografia e Planejamento & Horieste Gomes & 61 & 1984 \\
\hline $\begin{array}{l}\text { Paradigma e movimento social: por } \\
\text { onde andam nossas ideias? }\end{array}$ & $\begin{array}{l}\text { L. A. Machado da Silva, Ana } \\
\text { Clara T. Ribeiro }\end{array}$ & 62 & 1985 \\
\hline $\begin{array}{l}\text { Estado, Divisão Social do Trabalho } \\
\text { e Habitação }\end{array}$ & José Antônio Ronchezel & 64 & 1986 \\
\hline $\begin{array}{l}\text { Habitação e Espaço Social na } \\
\text { Cidade de São Paulo }\end{array}$ & $\begin{array}{l}\text { Arlete Moysés } \text { Rodrigues, } \\
\text { Manoel Seabra }\end{array}$ & 64 & 1986 \\
\hline $\begin{array}{lrr}\text { As condições de } & \text { existência de } \\
\text { parcelas } & \text { da } & \text { população } \\
\text { trabalhadora: } & \text { a } & \text { questão da } \\
\text { habitação } & & \end{array}$ & Regina Célia Bega dos Santos & 64 & 1986 \\
\hline $\begin{array}{l}\text { Cubatão: na busca das favelas e o } \\
\text { encontro do "peão" que permanece }\end{array}$ & Amélia Luisa Damiani & 64 & 1986 \\
\hline $\begin{array}{l}\text { Situação habitacional no Brasil e a } \\
\text { utilização de processos de } \\
\text { autoajuda e ajuda-mútua na } \\
\text { produção de moradias }\end{array}$ & Ros Mari Zenha Kaupatez & 64 & 1986 \\
\hline $\begin{array}{l}\text { Indústria da construção - reflexão } \\
\text { sobre o "atraso tecnológico" }\end{array}$ & Ermínia Maricato & 64 & 1986 \\
\hline $\begin{array}{l}\text { Passado e presente das relações } \\
\text { entre sociedade e espaço e } \\
\text { localização pontual da indústria } \\
\text { moderna no Estado da Bahia }\end{array}$ & Milton Santos & 65 & 1987 \\
\hline $\begin{array}{l}\text { Os shopping-center brasileiros e o } \\
\text { processo de valorização do espaço } \\
\text { urbano }\end{array}$ & Silvana Maria Pintaudi & 65 & 1987 \\
\hline $\begin{array}{l}\text { Terceirização } \\
\text { metropolitano }\end{array}$ & $\begin{array}{l}\text { Christian Dennis Monteiro de } \\
\text { Oliveira }\end{array}$ & 65 & 1987 \\
\hline $\begin{array}{l}\text { A intervenção do estado nas } \\
\text { transformações do espaço urbano - } \\
\text { caso Cura em Cuiabá }\end{array}$ & $\begin{array}{l}\text { Cornélio Silvano } \text { Vilarinho } \\
\text { Neto }\end{array}$ & 65 & 1987 \\
\hline $\begin{array}{l}\text { Mudanças nas formas de comércio } \\
\text { varejista e a implantação dos } \\
\text { supermercados na Grande São } \\
\text { Paulo - SP - Brasil }\end{array}$ & Silvana Maria Pintaudi & 66 & 1988 \\
\hline $\begin{array}{l}\text { O processo de terceirização do } \\
\text { espaço metropolitano: um estudo } \\
\text { sobre sua realização na regional } \\
\text { administrativa de Santo Amaro - } \\
\text { São Paulo }\end{array}$ & $\begin{array}{l}\text { Christian Dennys Monteiro de } \\
\text { Oliveira }\end{array}$ & 66 & 1988 \\
\hline $\begin{array}{l}\text { Mapeamento das causas de morte } \\
\text { no município de São Paulo: } \\
\text { Subsídios de uma Geografia } \\
\text { Médica da cidade }\end{array}$ & Helena Ribeiro Sobral & 66 & 1988 \\
\hline
\end{tabular}




\begin{tabular}{|c|c|c|c|}
\hline $\begin{array}{l}\text { Pensando o processo } \\
\text { valorização e a Geografia }\end{array}$ & $\begin{array}{l}\text { Odette Carvalho de Lima } \\
\text { Seabra }\end{array}$ & 66 & 1988 \\
\hline $\begin{array}{l}\text { Migrações, Urbanização e o Setor } \\
\text { Informal: Estudo sobre as Formas } \\
\text { de Comercialização em Área de } \\
\text { Emigração para as Metrópoles de } \\
\text { São Paulo e Rio de Janeiro (Brasil) }\end{array}$ & Nilson Crocia de Barros & 66 & 1988 \\
\hline Paraná que se acaba? & $\begin{array}{l}\text { Denise Rockenbach, Glória da } \\
\text { Anunciação Alves }\end{array}$ & 66 & 1988 \\
\hline $\begin{array}{l}\text { Materiais para o estudo da } \\
\text { urbanização brasileira no período } \\
\text { técnico científico }\end{array}$ & Milton Santos & 67 & 1989 \\
\hline Bixiga: uma ideologia geográfica & Francisco Capuano Scarlato & 67 & 1989 \\
\hline
\end{tabular}

Organizado pela autora. Fonte: AGB - São Paulo.

A edição de número 64 foi feita como uma forma de homenagear José Antonio Rochenzel, professor da UNESP que havia falecido no ano anterior. Rochenzel faleceu voltando para casa após marcar a defesa de sua dissertação de mestrado na FFLCH da USP, cujo título do trabalho era "Invasão de imóveis para a moradia: lutas populares pelo direito à cidade". Assim, na impossibilidade de publicar sua dissertação, o trabalho "Estado, divisão social do trabalho e habitação" escrito por ele na graduação é o primeiro texto do boletim de número 64. Publicam nessa edição também pesquisadores (quase todos geógrafos) que partilhavam da mesma vontade em compreender o espaço urbano com olhares críticos, como Arlete Moyses Rodrigues e Manoel Seabra, que escreveram o artigo "Habitação e Espaço Social na Cidade de São Paulo"; Regina Célia Bega dos Santos que escreveu "As condições de existência de parcela da população trabalhadora: A questão da Habitação"; Amélia Luisa Damiani, autora de "Cubatão: na busca das favelas e o encontro do peão que permanece"; Ros Mari Zenha Kaupatez que escreveu "Situação Habitacional no Brasil e a utilização de processos de autoajuda e ajuda-mútua na produção de moradias" e Ermínia Maricato com o artigo "Indústria da construção reflexão sobre o atraso tecnológico".

Chama a atenção a preocupação com o tema da habitação nesse boletim da AGB, que só havia aparecido uma única vez em um texto escrito sob a perspectiva da geografia quantitativa e que a partir de então ganharia peso. Assim, percebemos que a temática da moradia da classe trabalhadora aparece na geografia urbana em um período em que a reforma urbana estava sendo amplamente discutida. Também é interessante que a 
arquiteta e urbanista Ermínia Maricato tenha publicado um artigo nessa edição, reforçando o interesse dos geógrafos em debater o tema.

Nesse sentido, é possível fazer um paralelo com a análise de Maricato (2016) sobre o pensamento crítico sobre a cidade capitalista periférica e a disputa ideológica da representação da cidade. Para a autora, os intelectuais dedicados aos espaços de moradia precária, especialmente a partir dos anos de 1970, criaram uma nova consciência sobre o universo da informalidade, da segregação e da pobreza e o morador das favelas que antes desse período era considerado marginal, passou a ser visto como trabalhador. Maricato cita nomes pioneiros nessa discussão do urbano "a contrapelo", como Carlos Lemos e Maria Ruth Amaral Sampaio (1978), Sérgio Ferro (1969), Ermínia Maricato (1976; 1979), Maria de Azevedo Brandão (1980), Nabil Bonduki e Raquel Rolnik (1979), Lúcio Kowarick (1979) etc. A urbanista cita também os trabalhos do engenheiro Nilton Vargas (1979) e as pesquisas da área do Direito, como aquelas que deram origem à série "Direito Insurgente", promovida pelo Centro de Defesa dos Direitos Humanos de Petrópolis. Outra lembrança de Maricato foi a Reunião Anual da Sociedade Brasileira para o Progresso da Ciência - SBPC em 1976, quando foram apresentados o documentário Fim de Semana, dirigido por Renato Tapajós, e um texto de Maricato (1976), que serviram de base para uma discussão sobre a casa popular e a análise fundamentada em Francisco de Oliveira (1972) sobre o papel da autoconstrução no rebaixamento do preço da força de trabalho.

Assim, é possível atualizar essa importante discussão sobre a consciência do urbano feita por Maricato e incluir os pensadores pioneiros que partem da Geografia (crítica) para compreender a realidade de exclusão social no âmbito da cidade/urbano. Os geógrafos também trabalharam na busca de uma leitura do espaço urbano comprometida com o social e os trabalhos publicados no BPG, número 64, dão algumas pistas daqueles que se dedicariam à questão. Outro trabalho que vale a pena ser consultado é o artigo escrito por Maurício de Abreu (1994), intitulado "Estudo Geográfico da Cidade no Brasil: evolução e avaliação (contribuição à história do pensamento geográfico brasileiro)". O autor faz um completo retrospecto das principais publicações em geografia urbana, mostrando a importância dos geógrafos no pensamento crítico sobre o tema.

A partir de 1987 no BPG os temas se diversificam diante de uma nova problemática do urbano: os shoppings, a terceirização, localização industrial (em momentos que se vive a reestruturação urbano-industrial), a geografia médica, a valorização do espaço, migrações etc. 
Quadro 7 - Publicações sobre cidade e o urbano no BCG (Década de 1980)

Legenda:

Geografia Crítica

\begin{tabular}{|c|c|c|c|c|}
\hline Título do artigo & Autor & $\mathbf{N}^{\mathbf{0}}$ & Vol & Ano \\
\hline Função Regional de Formosa & Lucio de Castro Soares & 2 & I & 1948 \\
\hline Região Centro-Ocidental da Bahia & Alfredo J. P. Domingues & 3 & I & 1948 \\
\hline Uma Viagem ao Planalto Central & Speridião Faissol & 5 e 6 & $\mathrm{I}$ & 1948 \\
\hline $\begin{array}{l}\text { Duas Vilas no Estado de Santa } \\
\text { Catarina }\end{array}$ & Victor Peluso Jr & 5 e 6 & I & 1948 \\
\hline $\begin{array}{l}\text { Aspectos } \quad \text { Geográficos do } \text { Bas } \\
\text { Languedoe: } \text { Região de Montpellier }\end{array}$ & Elza Coelho de Sousa & 5 e 6 & $\mathrm{I}$ & 1948 \\
\hline $\begin{array}{l}\text { Contribuição ao Estudo da Ocupação } \\
\text { Humana do Território do Amapá }\end{array}$ & Lúcio de Castro Soares & 2 e 3 & I & 1948 \\
\hline $\begin{array}{l}\text { As Veredas e os Gerais na região do } \\
\text { Rio Preto na Bahia (estudo de } \\
\text { geografia humana) }\end{array}$ & Pedro Geiger & 1 & III & 1950 \\
\hline $\begin{array}{l}\text { Notas Sobre a Cidade de Diamantina } \\
\text { e seus Habitantes }\end{array}$ & $\begin{array}{l}\text { Lysia Maria Cavalcante } \\
\text { Bernardes }\end{array}$ & 2 e 3 & III & 1950 \\
\hline A Colonização no Estado de Goiás & Speridião Faissol & 2 e 3 & III & 1950 \\
\hline $\begin{array}{l}\text { A Cidade de Cruzeiro - Notas de } \\
\text { Geografia Urbana }\end{array}$ & Nilo Bernardes & $1 \mathrm{e} 2$ & $\mathrm{~V}$ & 1952 \\
\hline $\begin{array}{l}\text { Notas para o Estudo do Núcleo } \\
\text { Colonial de Santa Cruz (Secção de } \\
\text { Piranema) }\end{array}$ & $\begin{array}{ll}\text { Delnida } & \text { Martinez } \\
\text { Alonso } & \end{array}$ & 1 e 2 & VIII & 1955 \\
\hline $\begin{array}{l}\text { Reconhecimento Geográfico } \\
\text { Município de Pompéu, M.G. }\end{array}$ & Orlando Valverde & 1 e 2 & VIII & 1955 \\
\hline $\begin{array}{l}\text { Análise preliminar dos tipos de } \\
\text { povoamento no } \\
\text { principalmente sob o ponto de vista } \\
\text { de sua morfologia }\end{array}$ & $\begin{array}{l}\text { José Veríssimo da Costa } \\
\text { Pereira }\end{array}$ & 3 e 4 & VIII & 1955 \\
\hline $\begin{array}{l}\text { Contrastes Regionais da terra norte - } \\
\text { americana }\end{array}$ & $\begin{array}{l}\text { José Veríssimo da Costa } \\
\text { Pereira }\end{array}$ & 3 e 4 & VIII & 1955 \\
\hline $\begin{array}{l}\text { Vargem Grande (alguns aspectos } \\
\text { geográficos) }\end{array}$ & Amélia Alba Nogueira & 1 e 2 & IX & 1956 \\
\hline $\begin{array}{l}\text { Origem e evolução urbana de } \\
\text { Garanhuns }\end{array}$ & Hilton Sette & 1 e 2 & IX & 1956 \\
\hline $\begin{array}{l}\text { Exemplos de hierarquia de cidades no } \\
\text { Brasil }\end{array}$ & Pedro Pinchas Geiger & 3 e 4 & $\mathrm{X}$ & 1957 \\
\hline $\begin{array}{l}\text { A respeito de "Mapas econômicos das } \\
\text { cidades e regiões do Rio de Janeiro e } \\
\text { São Paulo }\end{array}$ & $\begin{array}{l}\text { Michel Blochu e Pedro } \\
\text { Pinchas Geiger }\end{array}$ & 3 e 4 & $\mathrm{X}$ & 1957 \\
\hline $\begin{array}{l}\text { Santa Teresa, um bairro residencial } \\
\text { no centro do Rio de Janeiro }\end{array}$ & $\begin{array}{lr}\text { Aluízio } & \text { Peixoto } \\
\text { Boynarde e } & \text { Maria } \\
\text { Thereza Soares } & \\
\end{array}$ & 1 e 2 & $\mathrm{XI}$ & 1958 \\
\hline
\end{tabular}




\begin{tabular}{|c|c|c|c|c|}
\hline $\begin{array}{l}\text { Alguns problemas sugeridos pelo } \\
\text { estudo da colonização alemã no Rio } \\
\text { Grande do Sul }\end{array}$ & Jean Roche & 1 e 2 & $\mathrm{XI}$ & 1958 \\
\hline A primeira vila portuguesa no Brasil & M. T. de Segadas Soares & $1 \mathrm{e} 2$ & $\mathrm{XI}$ & 1958 \\
\hline $\begin{array}{l}\text { O conceito geográfico de bairro e sua } \\
\text { exemplificação na cidade do Rio de } \\
\text { Janeiro }\end{array}$ & M. T. de Segadas Soares & 3 e 4 & $\mathrm{XI}$ & 1958 \\
\hline $\begin{array}{l}\text { Tipos de Localização de Cidades em } \\
\text { Pernambuco }\end{array}$ & Mário Lacerda de Melo & 3 e 4 & XI & 1958 \\
\hline $\begin{array}{l}\text { Evolução da paisagem urbana do Rio } \\
\text { de Janeiro até o início do século XX }\end{array}$ & $\begin{array}{l}\text { Lysia Maria Cavalcante } \\
\text { Bernardes }\end{array}$ & 1 e 2 & XII & 1959 \\
\hline $\begin{array}{l}\text { Notas de viagem à Costa do Marfim: } \\
\text { economia comercial e transformações } \\
\text { da paisagem geográfica na A. O.F. }\end{array}$ & Milton Santos & 1 e 2 & XII & 1959 \\
\hline $\begin{array}{l}\text { Meditação geográfica sobre o Rio de } \\
\text { Janeiro }\end{array}$ & Pierre Deffontaines & 3 e 4 & XII & 1959 \\
\hline $\begin{array}{l}\text { A organização urbana da Amazônia } \\
\text { Brasileira }\end{array}$ & Michel Rochefort & 3 e 4 & XII & 1959 \\
\hline $\begin{array}{l}\text { Função defensiva do Rio de Janeiro e } \\
\text { seu sítio original }\end{array}$ & $\begin{array}{l}\text { Lysia Maria Cavalcante } \\
\text { Bernardes }\end{array}$ & $1 \mathrm{e} 2$ & XIII & 1960 \\
\hline $\begin{array}{l}\text { Notas sobre a região de Ponte Nova e } \\
\text { Viçosa }\end{array}$ & Michel Tabutlau & $1 \mathrm{e} 2$ & XIII & 1960 \\
\hline $\begin{array}{l}\text { A Indústria em Brusque (Santa } \\
\text { Catarina) e suas consequências sobre } \\
\text { a vida urbana }\end{array}$ & Armen Mamigonian & 3 e 4 & XIII & 1960 \\
\hline $\begin{array}{l}\text { O problema da classificação do } \\
\text { habitat }\end{array}$ & Michel Rochefort & 1 e 2 & XIV & 1961 \\
\hline $\begin{array}{l}\text { Uma experiência de colonização na } \\
\text { Baixada Fluminense }\end{array}$ & Roberto Lobato Corrêa & 1 & XV & 1962 \\
\hline $\begin{array}{llll}\text { Aracajú, } & \text { síntese de } & \text { Geografia } \\
\text { Humana } & & & \\
\end{array}$ & $\begin{array}{l}\text { José Alexandre Felizola } \\
\text { Diniz }\end{array}$ & 1 & $\mathrm{XV}$ & 1962 \\
\hline $\begin{array}{l}\text { Alguns problemas das grandes } \\
\text { cidades nos países subdesenvolvidos }\end{array}$ & Milton Santos & 1 & XV & 1962 \\
\hline $\begin{array}{l}\text { Madureira - Tentativa de } \\
\text { determinação da área de influência de } \\
\text { um sub-centro da metrópole carioca }\end{array}$ & $\begin{array}{l}\text { Maria Francisca Tereza } \\
\text { Cavalcanti Cardoso e } \\
\text { Maria Emilia Teixeira } \\
\text { de Castro Botelho }\end{array}$ & 1 & $\begin{array}{l}\text { XVI } \\
\text { I }\end{array}$ & $\begin{array}{l}1965 / 1 \\
966\end{array}$ \\
\hline $\begin{array}{l}\text { As causas do crescimento recente de } \\
\text { Itaboraí - Vendas das Pedras }\end{array}$ & $\begin{array}{l}\text { Mauricio de Almeida } \\
\text { Abreu e Maria do } \\
\text { Socorro Diniz } \\
\end{array}$ & 1 & XXI & 1970 \\
\hline $\begin{array}{l}\text { Relações entre o Desenvolvimento } \\
\text { Econômico Regional e o Sistema } \\
\text { Urbano - O caso do Chile }\end{array}$ & Brian J. L. Berry & 1 & XXI & 1970 \\
\hline Regionalização - análise Quantitativa & Speridião Faissol & 1 & XXI & 1970 \\
\hline $\begin{array}{l}\text { Uma Medida da Função de Direção } \\
\text { das Cidades Brasileiras }\end{array}$ & $\begin{array}{l}\text { Ruth Lopes da Cruz } \\
\text { Magnanini e Olga Maria } \\
\text { Buarque de Lima }\end{array}$ & 1 & $\begin{array}{l}\text { XXI } \\
\mathrm{I}\end{array}$ & 1971 \\
\hline
\end{tabular}




\begin{tabular}{|c|c|c|c|c|}
\hline $\begin{array}{l}\text { Analise Fatorial de } \\
\text { Metropolitanas - Belo } \\
\text { Curitiba e Porto Alegre }\end{array}$ & $\begin{array}{l}\text { Elisa Mendes } \quad \text { de } \\
\text { Almeida e Olga } \\
\text { Buarque de Lima }\end{array}$ & 1 & $\begin{array}{l}\text { XXI } \\
\text { I }\end{array}$ & 1971 \\
\hline 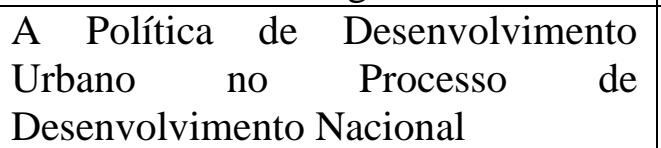 & Zila Mesquita Melo & 1 & $\begin{array}{l}\text { XXI } \\
\text { I }\end{array}$ & 1971 \\
\hline $\begin{array}{l}\text { Contribuição ao Estudo da Estrutura } \\
\text { Interna da Área Metropolitana do Rio } \\
\text { de Janeiro. O caso de Xerém (Duque } \\
\text { de Caxias) }\end{array}$ & \begin{tabular}{lll|} 
Gilda & \multicolumn{2}{c|}{ Campos } \\
Impellizieri & de $\quad \mathrm{S}$. \\
Martins & &
\end{tabular} & 1 & $\begin{array}{l}\text { XXI } \\
\text { I }\end{array}$ & 1971 \\
\hline $\begin{array}{l}\text { A Rede de Localidades Centrais do } \\
\text { Rio Grande do Sul, determinada } \\
\text { através da Teoria dos Grafos }\end{array}$ & Maria do Socorro Diniz & 1 & $\begin{array}{l}\text { XXI } \\
\text { I }\end{array}$ & 1971 \\
\hline $\begin{array}{l}\text { Um Aspecto da Urbanização no } \\
\text { Estado do Espírito Santo }\end{array}$ & Maria do Socorro Diniz & 1 & $\begin{array}{l}\text { XXI } \\
\mathrm{I}\end{array}$ & 1971 \\
\hline $\begin{array}{l}\text { Notas sobre aplicações de Modelo } \\
\text { Probabilístico de Distribuição Poison } \\
\text { ao Sistema Urbano }\end{array}$ & $\begin{array}{l}\text { Pedro Pinchas } \text { Geiger, } \\
\text { Joao Rua e Luiz } \\
\text { Antonio Ribeiro }\end{array}$ & 1 & $\begin{array}{l}\text { XXI } \\
\text { I }\end{array}$ & 1971 \\
\hline $\begin{array}{l}\text { Integração de Maricá à área } \\
\text { metropolitana do Rio de Janeiro }\end{array}$ & $\begin{array}{l}\text { Marlene Teixeira e } \\
\text { William G. Soares }\end{array}$ & 1, & $\begin{array}{l}\text { XXI } \\
\text { V }\end{array}$ & $\begin{array}{l}1973 / 1 \\
974 / 19 \\
75\end{array}$ \\
\hline Fusão Guanabara-Rio de Janeiro & $\begin{array}{l}\text { Antônio José Teixeira } \\
\text { Guerra }\end{array}$ & 1 & $\begin{array}{l}\mathrm{XX} \\
\mathrm{V}\end{array}$ & 1976 \\
\hline $\begin{array}{l}\text { O processo de urbanização no } \\
\text { continente africano }\end{array}$ & $\begin{array}{l}\text { Iná Elias de Castro, } \\
\text { Naria Helena Lacorte e } \\
\text { Nelza Araújo }\end{array}$ & 1 & $\begin{array}{l}\mathrm{XX} \\
\mathrm{V}\end{array}$ & 1976 \\
\hline O Povoamento do Nordeste & Hilda da Silva & 2 & $\begin{array}{l}\text { XX } \\
\text { VI }\end{array}$ & 1976 \\
\hline O Sistema Urbano do Nordeste & Hilda da Silva & 2 & $\begin{array}{l}\text { XX } \\
\text { VI }\end{array}$ & 1976 \\
\hline $\begin{array}{l}\text { Mudanças de população: um estudo } \\
\text { de pequenas cidades nos estados do } \\
\text { Maranhão, Pernambuco e São Paulo } \\
\text { no Brasil }\end{array}$ & Hilda da Silva & 2 & $\begin{array}{l}\text { XX } \\
\text { VI }\end{array}$ & 1976 \\
\hline $\begin{array}{l}\text { A natureza da política habitacional } \\
\text { para grupos de baixa e média renda no } \\
\text { Rio de Janeiro e seus efeitos no } \\
\text { modelo residencial da referida cidade }\end{array}$ & Hilda da Silva & 2 & $\begin{array}{l}\text { XX } \\
\text { VI }\end{array}$ & 1976 \\
\hline Divisão Regional do Brasil & $\begin{array}{l}\text { Fábio Macedo Soares } \\
\text { Guimarães }\end{array}$ & 1 & $\begin{array}{l}\text { XX } \\
\text { VII }\end{array}$ & $\begin{array}{l}1977 / 1 \\
978\end{array}$ \\
\hline \begin{tabular}{ll|}
$\begin{array}{l}\text { Desequilíbrios } \\
\text { formulações teóricas }\end{array}$ & regionais- \\
\end{tabular} & $\begin{array}{l}\text { Maria Francisca } \\
\text { Thereza C. Cardoso }\end{array}$ & 1 & $\begin{array}{l}\text { XX } \\
\text { VII }\end{array}$ & $\begin{array}{l}1977 / 1 \\
978\end{array}$ \\
\hline $\begin{array}{l}\text { Análise de critérios de população na } \\
\text { identificação de zonas internas na } \\
\text { região metropolitana do Rio de } \\
\text { Janeiro }\end{array}$ & $\begin{array}{l}\text { Haidina da S. B. Duarte } \\
\text { e William Gonçalves } \\
\text { Soares }\end{array}$ & 1 & $\begin{array}{l}\text { XX } \\
\text { VII }\end{array}$ & $\begin{array}{l}1977 / 1 \\
978\end{array}$ \\
\hline $\begin{array}{l}\text { Urbanização e migração na Amazônia } \\
\text { Legal: sugestão para uma abordagem } \\
\text { geopolítica }\end{array}$ & Lia Osório Machado & 1 & $\begin{array}{l}\text { XX } \\
\text { XII }\end{array}$ & 1982 \\
\hline
\end{tabular}




\begin{tabular}{|l|l|l|l|l|}
\hline $\begin{array}{l}\text { Organização do espaço e organização } \\
\text { social: o caso de Rondônia }\end{array}$ & Milton Santos & 1, & $\begin{array}{l}\text { XX } \\
\text { XII }\end{array}$ & 1982 \\
\hline
\end{tabular}

Organizado pela autora. Fonte: AGB - Rio de Janeiro.

As publicações em geografia urbana mais alinhadas com a geografia crítica que destacamos no BCG são duas que aparecem no Boletim de volume XXXII. Ambas tratam da realidade da região Norte, analisando o espaço e a prática social de uma forma interdependente, com teores de denúncia dos processos que estavam ocorrendo em cada um dos recortes e identificando sujeitos envolvidos.

\subsection{Reconhecimentos e limitações do papel da AGB na luta pela reforma urbana}

Neste processo, percebemos também as limitações da prática da AGB nesse período da década de 1980 e começo da década de 1990 e que podem ser aplicadas também para os dias de hoje, apesar de algumas mudanças de contextos. Notamos que mais adequado do que falar da atuação de uma Seção Local ou da AGB Nacional, é falar sobre a participação de alguns geógrafos que incentivaram, fizeram, estudaram, mobilizaram.... Enfim, assumiram uma postura mais forte nessas lutas pela reforma urbana.

Nos documentos da AGB que tivemos acesso e que tratavam de eventos ou de reuniões relacionados ao Fórum Nacional de Reforma Urbana, as pessoas que constavam como presentes estavam ligadas à Comissão de Assuntos Urbanos e, muitas vezes, tratava-se de uma quantidade pequena de geógrafos que realmente comparecia.

Além disso, os relatos sobre a luta pela reforma urbana a partir das experiências de dentro da AGB nesses anos da virada da década de 1980 para 1990 foram escritos apenas por alguns geógrafos, como é o caso dos professores Arlete Moyses Rodrigues e Willian Rosa. No entanto, quando o tema é a reforma urbana em geral e o recorte temporal é estendido até os dias de hoje, aumenta o número de geógrafos preocupados em escrever sobre o tema, como é o caso de José Borzachiello da Silva, Jan Bitoun, Marcelo Lopes de Souza etc.

Outra questão é que muitos sujeitos da AGB que atuaram na luta pela reforma urbana não tiveram destaque nesse capítulo por causa do recorte temporal da pesquisa. 
Nossa preocupação foi analisar o (re)início da luta pela reforma urbana que vem com a Constituinte e seus desdobramentos mais imediatos, como a criação do Fórum Nacional de Reforma Urbana. Correndo o risco de cometer injustiças com algumas pessoas, citamos o caso dos geógrafos Yure Silva e Jan Bitoun, que junto com Arlete Moyses Rodrigues, foram os representantes da AGB no Conselho das Cidades a partir de 2003, órgão consultivo do Ministério das Cidades. Ambos os espaços foram conquistados pelas lutas, mas infelizmente foram extintos nesses últimos anos.

Algumas Seções Locais da AGB nas regiões metropolitanas do país também tiveram participações localizadas sobre a questão urbana, como é caso de Belo Horizonte, Porto Alegre, Presidente Prudente, Aracaju, Fortaleza etc. Não é o interesse dessa pesquisa unir todos esses fragmentos, até mesmo porque a proposta da pesquisa é entender a inserção da AGB na agenda da luta pela reforma urbana, que é nacional e centralizada, mesmo se dando a partir das instâncias regionais. Além disso, a dificuldade para obter tais informações é grande, já que a própria existência das Seções Locais da AGB é irregular em função das dificuldades de mantê-las com pessoas atuando de forma constante e difícil de mapear por conta dessas interrupções das atividades. Essas inconstâncias, em alguns casos, acontecem em função do próprio cotidiano acadêmico ou escolar, e os problemas dos alunos e dos professores ficam ainda maiores quando as Seções estão vinculadas às regiões e universidades com menos investimentos.

As questões locais não são o foco da pesquisa. No entanto, concordamos com Jan Bitoun de que a capilaridade da AGB é importante e poderia ser usada para articular as diferentes escalas na direção de uma geografia crítica. Segundo o professor:

[...] a maioria das políticas concretizam-se em normas que, com frequência ignoram a diversidade de situações. Concentram-se no mainstream, nos grupos mais organizados e ficam atingidas de cegueira em relação a muitas situações. Considero que é papel da geografia fazer aparecer as situações de invisibilidade (Jan Bitoun, entrevista a Larissa Araujo, abril de 2018).

Consideramos o posicionamento do professor como mais uma das contradições que fomos nos deparando ao longo da pesquisa. Afinal, parte importante da luta pela reforma urbana passou a ter relação com o âmbito jurídico e institucional, enquanto que as lutas no espaço urbano são mais diversas e muitas vezes não conseguem sequer um diálogo com o poder público. Nessa pesquisa procuramos evidenciar a inserção da AGB, 
ou de alguns geógrafos que nela atuaram, em lutas urbanas que em alguma medida foram se institucionalizando em leis, conselhos etc. Mesmo assim, apesar de não ser o único caminho, nem serem as únicas vozes que denunciam, reivindicam e se indignam sobre o urbano, vemos essas lutas como resultado de uma mobilização rica em termos de aprendizado e organização, que deram importantes contribuições à sociedade.

Esperamos que após esse retrospecto dado desde o surgimento da geografia moderna no Brasil, novas perguntas surjam e que, na tentativa de respondê-las, cheguemos cada vez mais perto em entender qual o papel do geógrafo, da geografia urbana e da AGB nesse país onde a miséria e a exclusão são parte de uma realidade desigual e que não devemos nos furtar de analisar ao observar o espaço urbano. 


\section{CONSIDERAÇÕES FINAIS}

A geografia urbana passou por várias transformações. Monografias urbanas, redes urbanas, busca de padrões matemáticos possibilitado pelo uso dos computadores...

Muitos trabalhos feitos a partir dos métodos das monografias urbanas são dignos de consulta até hoje. No entanto, não davam conta de compreender os processos e nem os conflitos que se davam no espaço urbano em plena expansão. A geografia aplicada, seja as das redes ou aquela dos números, também não acompanhava o movimento geral da sociedade, tampouco conseguia contemplar processos e as lutas urbanas.

Em meio à ditadura militar e com os problemas urbanos se agravando nas periferias das grandes cidades, muitos geógrafos assumiram que não era possível analisar a realidade com os métodos e instrumentos que estavam disponíveis. Surgem novas formulações que tinham o compromisso com a transformação da sociedade que se estuda.

Os Encontros Nacionais de Geógrafos que ocorreram na década de 1970, apesar de toda a censura imposta pelo regime, exteriorizaram esse embate teórico-metodológico entre a Geografia que depois se denomina crítica e a geografia quantitativa. O ENG de Fortaleza, além de representar um momento de força da primeira, também foi muito importante para os rumos que a AGB tomaria a partir de então.

As práticas dos geógrafos ligadas ao planejamento e que eram discutidas não apenas no IBGE, mas também nos Encontros da AGB e em alguma medida nas universidades, também não bastavam, e foram recuando ao longo da década de 1980. Após as reformulações que vinham acontecendo na Geografia, a Constituinte representou uma possibilidade ampla para os geógrafos de atuarem mais próximos dos assuntos da sociedade civil, pensando nas demandas da classe trabalhadora. Foi assim que a AGB se inseriu na luta pela reforma urbana, participando ativamente do Movimento e do Fórum Nacional da Reforma Urbana.

Nesse sentido, entender a inserção dos geógrafos na luta pela reforma urbana, sobretudo por meio da AGB, é possível através do processo que levou a essa participação. Esse movimento foi resultado de mudanças teóricas - frutos de muitos embates, encontros acalorados, resistências em meio à ditadura militar. Foi resultado também de um 
entendimento de que as práticas não podiam acontecer somente dentro dos escritórios e nos planos de governo.

Hoje esbarramos em novas limitações, novas contradições. Alguns entendem essas limitações como uma consequência da democratização da AGB, do fím da hierarquização entre os sócios da entidade e da interrupção das atividades de planejamento, como se estas tivessem sido as razões para um maior esvaziamento das atividades dos geógrafos e da $\mathrm{AGB}$ na atualidade. Nós não vemos dessa maneira. $\mathrm{O}$ caminho seguido pela AGB era necessário e seguiu a dinâmica geral da sociedade de luta pela democracia. Não era possível também continuar com os discursos da neutralidade da ciência e nem do planejamento como algo sagrado. Sem negar as nossas deficiências, entendemos que as origens das limitações que nos deparamos também estão inseridas numa totalidade maior, que é política e econômica, e atingem ao mesmo tempo outros setores da sociedade. Exemplo é a recente extinção do Ministério das Cidades e do Conselho das Cidades, onde a AGB tinha um assento como representante.

Cabe a nós, agora, olharmos para esse processo e para o que está posto e pensarmos juntos: como avançar? Como recuperar as práticas, ressignificando-as? Como construir um planejamento alternativo, como o nomeou a geógrafa Arlete Moyses? Como nos inserir novamente nos espaços de luta contribuindo com a sociedade a partir da geografia urbana que desenvolvemos nas nossas universidades?

Pensamos que muitos estudos podem ser identificados ou serem continuados a partir desse tema, contribuindo para o entendimento de algumas dessas perguntas que fazemos e levantando novas questões. Além disso, a AGB e seus Grupos de Trabalho também podem ser pontos de partida importantes para uma inserção mais incisiva dos geógrafos na sociedade.

Os geógrafos assumiram vários papeis. São sujeitos que planejaram, escreveram, fizeram ciência, lutaram. Temos muito a dizer sobre o urbano e sobre a política. Cabe a nós dizermos como. 


\section{REFERÊNCIAS BIBLIOGRÁFICAS}

ABRAMO, Laís Wendel. Greve metalúrgica em São Bernardo: sobre a dignidade do trabalho. In: In: KOWARICK, Lúcio (org). As lutas sociais e a cidade. São Paulo: passado e presente. Rio de Janeiro: Paz e Terra, 1994.

ABREU, Maurício. O estudo geográfico da cidade no Brasil: evolução e avaliação contribuição à história do pensamento geográfico brasileiro. Revista Brasileira de Geografia, v.56, 1994.

ALMEIDA, R. S. A geografia e os geógrafos do IBGE do período 1938-1998. Tese (doutorado) - Universidade Federal do Rio de Janeiro, Programa de Pós Graduação em Geografia, 2000.

ALVES, William Rosa. A permanente busca do horizonte: a história da AGB - BH. Terra Livre, São Paulo, v. 1, n. 22, 2004.

ANDRADE, M. C. O pensamento geográfico e a realidade brasileira. Boletim Paulista de Geografia, n. 54, 1977

ANTUNES, C. da F; NETO, M. F. de S. Os estudantes, a Associação dos Geógrafos Brasileiros (AGB) e o movimento de renovação crítica da geografia brasileira. Boletim Paulista de Geografia, São Paulo, n. 88, 2008.

ANTUNES, C. da F. Os Estudantes e a Construção da Geografia Brasileira: um encontro nos Encontros Nacionais de Estudantes de Geografia (Mestrado em Geografia) Universidade Federal Fluminense, Niterói, 2001.

A Associação dos Geógrafos Brasileiros (AGB) - origens, ideias

e transformações: notas de uma história (Doutorado em Geografia) - Universidade Federal Fluminense, Niterói, 2008.

ARAVECCHIA-BOTAS, N. Estado, Arquitetura e Desenvolvimento: A ação Habitação do Iapi. São Paulo: Unifesp, 2016.

BARTHOLL, Timo. Por uma geografia em movimento. A ciência como ferramenta de luta. Rio de Janeiro: Editora Consequência, 2018.

BOMFIM, P. R. A. A Ostentação Estatística (um projeto geopolítico para o território nacional: Estado e planejamento no período pós-64). Tese (doutorado). Universidade de São Paulo, Programa de Pós Graduação em Geografia Humana, 2007.

BONDUKI, N. Crise de habitação e luta pela moradia no pós guerra. In: KOWARICK, Lúcio (org). As lutas sociais e a cidade. São Paulo: passado e presente. Rio de Janeiro: Paz e Terra, 1994.

BONDUKI, N (org). A luta pela reforma urbana no Brasil. Do Seminário de Habitação e Reforma Urbana ao Plano Diretor de São Paulo. BONDUKI, N. Do governo Vargas ao 
Seminário de Habitação e Reforma Urbana: as tentativas pioneiras de enfrentar a questão urbana. São Paulo: Instituto Casa da Cidade, 2018.

A luta pela reforma urbana no Brasil. Do Seminário de Habitação e Reforma Urbana ao Plano Diretor de São Paulo. LUCCHESE, M. C.; ROSSETO, R. A política urbana no governo militar (1964-1985). São Paulo: Instituto Casa da Cidade, 2018.

BONDUKI, N.; KOWARICK, L. Espaço urbano e espaço político: do populismo à redemocratização. In: KOWARICK, L (orgs). As lutas sociais e a cidade. São Paulo: passado e presente. Rio de Janeiro: Paz e Terra, 1994.

BRANT, Vinícius Caldeira. Da resistência aos movimentos sociais: a emergência das classes populares em São Paulo. In: SINGER, P.; BRANT, V. C. São Paulo: o povo em movimento. Petrópolis: Editora Brasileira de Ciências Ltda, 1982.

BRASIL. Ministério do Planejamento e Coordenação Econômica. Plano Decenal de Desenvolvimento Econômico e Social. Brasília, DF, 1967.

BRASIL. Secretaria de Planejamento. II Plano Nacional de Desenvolvimento (19751979). Brasília, DF, 1974.

BRUNA, Gilda Collet; STEINBERGER, Marília. Cidades médias: elos do urbanoregional e do público-privado. In: ANDREADE, Thompson Almeida; SERRA, Rodrigo Valente (orgs). Cidades Médias Brasileiras. Rio de Janeiro: Ipea, 2001.

CARLOS, Ana Fani. A condição espacial. São Paulo: Editora Contexto, 2016.

COMISSÃO DA VERDADE DA UNIVERSIDADE DE SÃO PAULO. Assessoria Especial de Segurança da Universidade de São Paulo. Universidade de São Paulo, v. 1, 2018.

COMISSÃO DA VERDADE DA UNIVERSIDADE DE SÃO PAULO. Faculdade de Filosofia, Letras e Ciências Humanas - IPM e cassados. Universidade de São Paulo, v. 7, 2018.

COMISSSÃO REDATORIAL. Editorial. Boletim Paulista de Geografia, nº 54, 1977.

COMISSÃO REDATORIAL. Editorial. Boletim Paulista de Geografia, n55, 1978.

COMISSSÃO REDATORIAL. Editorial. Boletim Paulista de Geografia, nº 60, 1982

CONTEL, F. B. As divisões regionais do IBGE no século XX (1942, 1970 e 1990).

Revista Terra Brasilis. Consultado em 13 de janeiro 2020. URL: http://journals.openedition.org/terrabrasilis/990; DOI:10.4000/terrabrasilis.990. 
CAMARGO, C.; SOUZA, B. M; PIERUCCI, A. F. O. Comunidades Eclesiais de Base. In: SINGER, P.; BRANT, V. C. São Paulo: o povo em movimento. Petrópolis: Editora Brasileira de Ciências Ltda, 1982.

DAMIANI, Amélia. L. A geografia e a produção do espaço na metrópole: entre o público e o privado. In: CARLOS, A. F. e CARRERAS, C (Org.). Urbanização e mundialização: estudos sobre a metrópole. São Paulo: Contexto, 2004.

DAMIANI, Amélia L. A metrópole e a indústria: reflexões sobre uma urbanização crítica. Terra Livre, São Paulo, n. 15, 2000.

FERNANDES, Ana. Reforma Urbana no Brasil: inquietações e explorações acerca de sua construção enquanto campo e política. In: LEME, Maria Cristina da S. Urbanismo e política no Brasil dos anos 1960. São Paulo: Annablume, 2019.

FERREIRA, Regina F. C. F. Movimentos sociais, autogestão e a construção da política nacional de habitação no Brasil. In: LAGO, L. C. (Org). Autogestão habitacional no Brasil: utopias e contradições. Rio de Janeiro: Letra Capital, 2012.

FERRO, Sérgio. A casa popular. São Paulo: Gfau, 1969.

FAISSOL, E. Planejamento e geografia: exemplos da experiência brasileira. Revista Brasileira de Geografia, Rio de Janeiro, v. 50, t. 2, 1988.

GALVÃO, M. V.; FAISSOL, E; LIMA, O. M. B.; ALMEIDA, E. M. J. M. Áreas de Pesquisa para Determinação de Áreas Metropolitanas. Revista Brasileira de Geografia, Rio de Janeiro, v. 31, n. 4, 1969.

GEIGER, P. Industrialização e urbanização no Brasil, conhecimento e atuação da geografia. Revista Brasileira de Geografia, Rio de Janeiro, v. 50, t. 2, 1988.

GOHN, Maria Clara. Os movimentos e as lutas dos períodos de 1964 a 2004 em São Paulo. In: VIII Congresso Luso-Afro Brasileiro de Ciências Sociais, 2004, Coimbra. Disponível em: https://www.ces.uc.pt/lab2004/pdfs/MariaGohn.pdf. Acesso em 10 de outubro de 2018.

GONÇALVES, C. W. P. A geografia está em crise. Viva a geografia! Boletim Paulista de Geografia, n. 55, 1978.

GUIMARÃES, Fábio de Macedo Soares. Divisão regional do Brasil. Revista Brasileira de Geografia, Rio de Janeiro, v. 3, n. 2, 1941.

KAUPATEZ, R. M. Zenha. Situação habitacional no Brasil e a utilização de processos de auto-ajuda e ajuda-mútua na produção de moradias. Boletim Paulista de Geografia. São Paulo, n. 64, 1986. 
KOWARICK, Lúcio; ANT, Clara. Cem anos de promiscuidade: o cortiço na cidade de São Paulo. In: In: SINGER, A.; ANT, C.; ABRAMO, L W; KOWARICK, L (org). As lutas sociais e a cidade. São Paulo: passado e presente. Rio de Janeiro: Paz e Terra, 1994.

LADOSKY, M. H.; OLIVEIRA, R. V. O “novo sindicalismo” pela ótica dos estudos do trabalho. Revista Mundos do Trabalho, v. 6, n. 11, 2014.

LOWY, Michel. "A contrapelo". A concepção dialética da cultura nas teses de Walter Benjamin (1940). Lutas sociais, n. 25/26, 2011.

MARICATO, Ermínia. Política Habitacional no Regime Militar. Do milagre brasileiro à crise econômica. Petrópolis: Editora Vozes, 1987.

O impasse da política urbana no Brasil. Petrópolis: Editora

Vozes,

2016.

MEIHY, José Carlos Sebe; HOLANDA, Fabíola. História oral. Como fazer, como pensar. São Paulo: Contexto, 2010.

MORAES, A. C. R. Geografia - Pequena História Crítica. São Paulo: Annablume, 2007.

MOYSES et al. Contradições Urbanas e Movimentos Sociais. Rio de Janeiro: Paz e Terra, Centros de Estudos de Cultura Contemporânea, 1978.

MULLER, N. L. Aspectos da vida da Associação dos Geógrafos Brasileiros. Boletim Paulista de Geografia, São Paulo, n. 38, 1961.

OLIVEIRA, Ariovaldo de. A lógica da especulação imobiliária. Boletim Paulista de Geografia, São Paulo, n. 55, 1978.

OLIVEIRA, Francisco de. Crítica à razão dualista. São Paulo: Boitempo, 2013.

PEREIRA, Diamantino A. C. A AGB, os movimentos sociais e a geografia: UPEGE, AGB e movimento estudantil no final da década de 70. Boletim Paulista de Geografia, n. $88,2008$.

PEREIRA, R.; DAVIDOCH, F.; GEIGER, P. P.; CORREIA, R. L. Estudos básicos para definição de pólos de desenvolvimento no Brasil - Informe ao Congresso de Integração Nacional realizado em Salvador, Bahia, no período de 12 a 17 de setembro de 1966. Revista Brasileira de Geografia, v. 29, n.1, 1967. 
PEIXOTO, Fernanda A. Franceses e Norte-Americanos nas Ciências Sociais Brasileiras 1930-1960. In: MICELI, Sérgio (org). História das Ciências Sociais no Brasil. São Paulo: Editora Sumaré, 1995.

RIBEIRO, Ana Clara T. Reforma urbana nos limites da modernização. In: Simpósio de Geografia Urbana, 3, 1993, Rio de Janeiro. Anais... Rio de Janeiro: AGB, 1993.

ROCHA, Genylton Odilon R. da. A Trajetória da Disciplina Geografia no Currículo Escolar Brasileiro (1938-1942). 1996. Dissertação (Mestrado em Educação) - Pontifícia Universidade Católica de São Paulo, São Paulo.

ROLNIK, Raquel. São Paulo, início da industrialização: o espaço e a política. In: KOWARICK, Lúcio. (org). As lutas sociais e a cidade. São Paulo: passado e presente. Rio de Janeiro: Paz e Terra, 1994.

RONCHEZEL, José Antônio. Estado, divisão social do trabalho e habitação. Boletim Paulista de Geografia. São Paulo, n. 64, 1986.

RODIGUES, Arlete; SEABRA, Manuel. Habitação e espaço social na cidade de São Paulo. Boletim Paulista de Geografia, São Paulo, n. 64, 1986.

RODRIGUES, Arlete M. Contribuição da AGB na construção da geografia brasileira Uma outra geografia sempre é possível. Terra Livre, São Paulo, v. 1, n. 22, 2004.

Algumas informações sobre a participação da AGB no Fórum da Reforma Urbana. Documento elaborado em 20 de janeiro de 2009. . AGB - Fórum da Reforma Urbana. Informes de 25 de janeiro de 2007.

Ponderações sobre ausências e presenças em estudos de Geografia Urbana. In: SPOSITO, Eliseu S.; SILVA, Charlei A.; NETO, João Lima S.; MELAZZO, Everaldo dos S. A diversidade da Geografia brasileira - Escalas e dimensões da análise e da ação. Rio de Janeiro: Consequência, 2016.

Planejamento e política urbana: desafios no contexto metropolitano. In: FERREIRA, A.; RUA, J.; MARAFON, Glaucio J.; SILVA, Augusto C. P. da. Metropolização do espaço - Gestão territorial e relações urbano-rurais. Rio de Janeiro: Consequência, 2013.

Desenvolvimento ou reforma urbana: concepções e contradições. In: Simpósio de Geografia Urbana, 3, 1993, Rio de Janeiro. Anais... Rio de Janeiro: AGB, 1993. 
SANTO AMORE, Caio. Entre o nó e o fato consumado, o lugar dos pobres na cidade. 2013. Tese (Doutorado em Planejamento Urbano e Regional). Faculdade de Arquitetura e Urbanismo, Universidade de São Paulo, São Paulo.

SANTOS, Regina C. Bega dos. As condições de existência de parcelas da população trabalhadora: a questão da habitação. Boletim Paulista de Geografia. São Paulo, n. 64, 1986.

SANTOS, Milton. Geografia e Desenvolvimento Econômico. A contribuição dos geógrafos ao planejamento. Revista Brasileira de Geografia. Rio de Janeiro, v.21, n.4, 1959.

. Para que a geografia mude sem ficar a mesma coisa. Boletim Paulista de Geografia, n. 59, 1982. . A urbanização brasileira. São Paulo: Hucited, 1993.

SAULE JÚNIOR, Nelson. Direito e Reforma Urbana. In: Simpósio de Geografia Urbana, 3, 1993, Rio de Janeiro. Anais... Rio de Janeiro: AGB, 1993.

SCARIM, Paulo C. A construção da geografia acadêmica no Brasil. Boletim Paulista de Geografia. São Paulo: AGB, n. 88, 2008.

SEABRA, Manuel. Caio Prado Jr. e os Primeiros Anos da AGB. In: SEABRA, Manuel; IUMATTI, Paulo; HEIDEMANN, Heinz D. Caio Prado Junior e a Associação dos Geógrafos Brasileiros. São Paulo: Edusp, 2008.

SECCO, Lincoln. História do PT. Cotia, SP: Ateliê Editorial, 2011.

SILVA, José Borzachiello. Movimentos sociais e processo de produção da cidade. In: SPOSITO, Eliseu S.; SILVA, Charlei A.; NETO, João Lima S.; MELAZZO, Everaldo dos S. A diversidade da Geografia brasileira - Escalas e dimensões da análise e da ação. Rio de Janeiro: Consequência, 2016.

SIMONI SANTOS, Cesar. A fronteira urbana. Urbanização, industrialização e mercado imobiliário no Brasil. São Paulo: Annablume, 2015.

SINGER, Paul. Movimentos de bairro. In: SINGER, P.; BRANT, V. C. São Paulo: $o$ povo em movimento. Petrópolis: Editora Brasileira de Ciências Ltda, 1982.

SOUZA, M. A. P. O II PND e a política urbana brasileira: Uma contradição evidente. CSABA, D; SCHIFFER, S. R. O processo de urbanização no Brasil. São Paulo: EDUSP, 2010. 
VERDI, Elisa F. Pensar radicalmente sob a repressão: a geografia crítica brasileira no contexto da ditadura civil-militar. Geousp-Espaço e Tempo, v. 22, n. 3, 2018.

Produção Geográfica e Ruptura Crítica: a Produção uspiana entre 1964

e 1985. 2016. Dissertação (Mestrado em Geografia Humana) - Departamento de Geografia, Universidade de São Paulo, São Paulo.

VIANA, Myrna. Editorial. Boletim Paulista de Geografia, nº51, 1977

VIEIRA, Alexandre; PEDON, Nelson R. O Papel das comunidades científicas: a AGB Nacional e a Seção Local de Presidente Prudente/SP. Terra Livre. São Paulo: AGB, n. 22, 2004.

ZUSMAN, Perla Brígida. Na procura das origens da AGB. Boletim Paulista de Geografia. São Paulo: AGB, n. 78, 2001.

\section{ENTREVISTAS REALIZADAS}

MOYSES, Arlete Rodrigues. Concedida a Larissa Araujo. Fevereiro de 2017.

BITOUN, Jan. Concedida a Larissa Araujo. Abril de 2018.

PEREIRA, Diamantino. Concedida a Larissa Araujo. Maio de 2018.

SANTOS, Douglas. Concedida a Larissa Araujo. Junho de 2018.

ESPÓSITO, Eliseu. Concedida a Larissa Araujo. Outubro de 2019.

SOUZA, Maria Adélia de. Concedida a Larissa Araujo. Novembro de 2019. 